Portland State University

PDXScholar

$1-1-1986$

\title{
Students in alternative public high schools: educational histories prior to alternative school entry
}

Carolyn Moilanen

Portland State University

Follow this and additional works at: https://pdxscholar.library.pdx.edu/open_access_etds Let us know how access to this document benefits you.

\section{Recommended Citation}

Moilanen, Carolyn, "Students in alternative public high schools: educational histories prior to alternative school entry" (1986). Dissertations and Theses. Paper 484.

https://doi.org/10.15760/etd.484

This Dissertation is brought to you for free and open access. It has been accepted for inclusion in Dissertations and Theses by an authorized administrator of PDXScholar. Please contact us if we can make this document more accessible: pdxscholar@pdx.edu. 
STUDENTS IN ALTERNATIVE PUBLIC HIGH SCHOOLS:

EDUCATIONAL HISTORIES PRIOR TO ALTERNATIVE SCHOOL ENTRY

by

CAROLYN MOILANEN

A dissertation submitted in partial fulfillment of the requirements for the degree of

DOCTOR OF EDUCATION

in

PUBLIC SCHOOL ADMINISTRATION \& SUPERVISION

Portland State University

University of Oregon

1986 
TO THE OFFICE OF GRADUATE STUDIES AND RESEARCH:

The Members of the Committee approve the dissertation of Carolyn Moilanen, presented July 2, 1986.

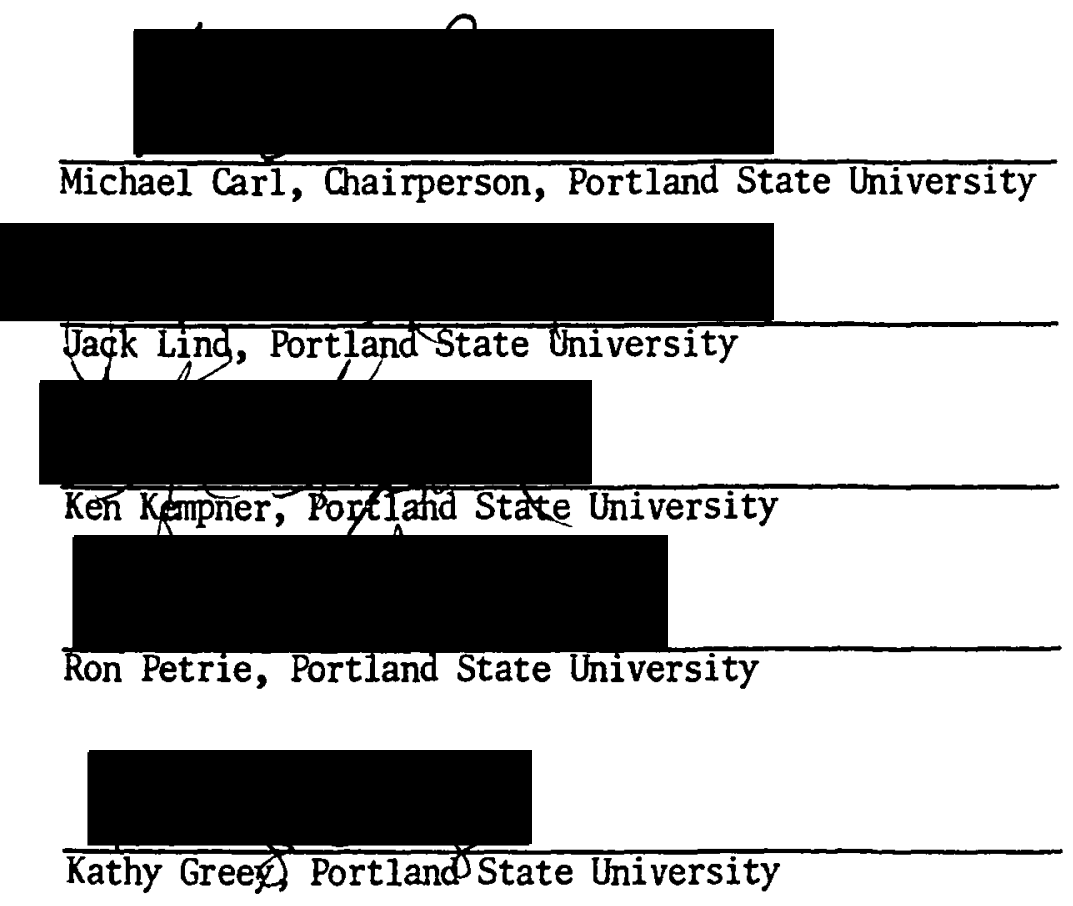

APPROVED:

Mary K. Kinfick, Bi-University Program Coordinator

(Portland State University)

Richard A. Schmuck, Bi-Unfivgrsity Program Coordinator

(University of Oregon)

Robert B. Everhart, Dean of the School of Education

(Portland State University)

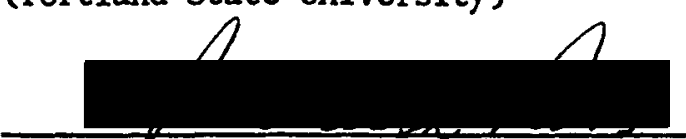

Bernard Ross, Dean of Graduate Studies and Research (Portland State University) 
AN ABSTRACT OF THE DISSERTATION OF Carolyn Moilanen for the Doctor of Education in Public School Administration and Supervision presented Juily $2,19806$.

Title: Students in Alternative Public High Schools: Educational Jistories Prior to Alternative School Entry

APPROVED BY MEMBERS OF THE DISSERTATION COMMITTEE:

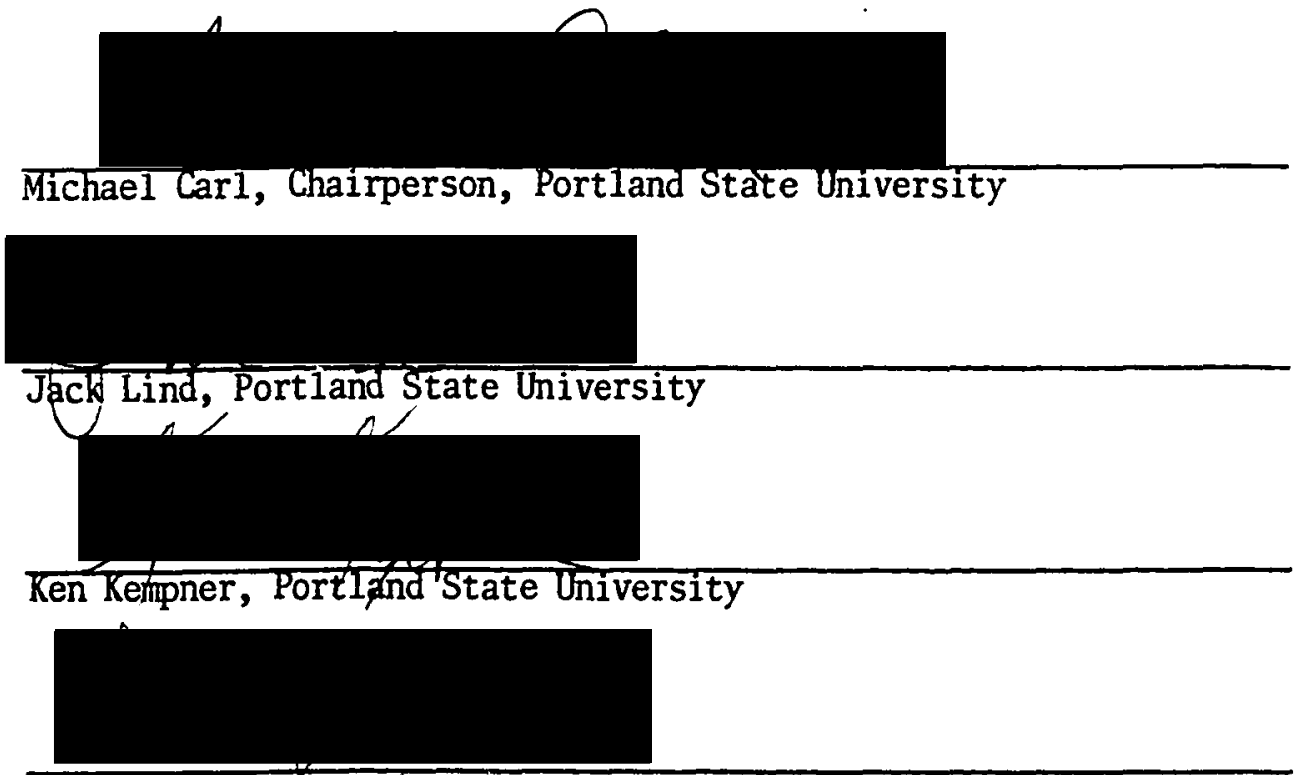

Ron Petrie, Portland State University

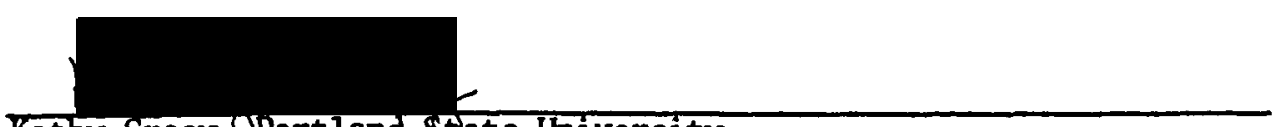

Kathy Greey,UPortland State University

There is much controversy regarding the effects of schooling and non-responsive delivery of educational services to potential dropout/high-risk students. At the same time there is evidence that school systems perceived as monolithic and non-responsive are broadly and deeply diverse in terms of programmatic offerings to meet the 
special needs of these students.

A comprehensive and comparative review of the three bodies of literature--dropout, supplementary/compensatory, and aiternative schools studies--suggests startling similarity among descriptors for dropout populations, for students with special learning needs, and for potential or real dropouts who participate in public high school alternative programs. Population characteristics, low academic performance, and dissatisfaction with school are common signs of potential dropout and signals for possible entry to public alternative schools.

The study was designed to describe an urban district's alternative high school population in terms of a conceptual framework drawn from three bodies of literature: dropout studies, supplementary/compensatory education, and alternative schools studies. Educational histories prior to alternative school entry were traced through district records and documents for 757 students and a focused interview was conducted with 81 students in order to obtain their perceptions of both regular and alternative educational experiences during their school careers. A qualitative data analysis was conducted to determine the study population fit with traditional descriptors for high-risk, to examine district responses in terms of educational program experiences in both regular and alternative schools, and to obtain insights into possible relationships between the two.

Overall, the sample population most clearly matched traditional personal/social descriptors for potential dropout/high-risk in terms of sex representation, between-district mobility, and because they had 
experienced some period of dropout. Nearly half the sample had been suspended at least once during district enrollment. There was less fit in terms of grade-level representation, minority enrollment and school achievement. Larger numbers of eleventh and twelfth graders were enrolled than the literature would suggest. Minority students, traditionally over-represented among dropouts, are under-represented in the sample programs. As a group, the population is achieving in terms of basic skills competencies tests, but over half the sample has a history of participation in supplementary/compensatory and/or other alternative programs early in their careers.

Students described teachers as the most critical component of their educational experience. While an instructional "helping" relationship and its consistent contribution to student success was often noted, a more personalized teacher-student relationship was mentioned even more frequently. Students identified early in their careers for supplementary/compensatory programs reported an affective as well as achievement-oriented dimension in those experiences, and described themselves as learners dependent upon the kind and level of individualized help and attention received in those settings and in the alternative setting as well. 
ACKNOWLEDGEMENTS

I wish to thank the members of my dissertation committee for their assistance and support. Special thanks are extended to Michael Carl, Chairperson. The services of Marty DeBoe and Michelle Batten were invaluable to the process of data collection and preparation of the manuscript. I am grateful to the staff and students of the alternative programs selected for the study; it was a particular pleasur ₹ to become acquainted with their contributions to public school education. 
ACCNOWLEDGEMENTS .............................. i

LIST OF TABLES ......................... vi

LIST OF FIGURES ................................. vii

CHAPTER

I INTRODUCTION ....................... 1

II REVIEW OF THE LITERATURE .............. 8

A. Review of the Dropout Literature ........ 10

Population Descriptors .......... 13

Personal and Social Characteristics

School-Related Characteristics

Predictors for Dropout

Self-Reported Reasons for Dropout

B. Review of Supplementary and Compensatory Educational

Programs .................... 26

Students and School Organization ........ 31

Tracking

Discipline Policy

C. Review of Alternative Schools Studies . . . . . 34

III METHODS AND PROCEDURES . . . . . . . . . . . 44

Research Design ............ 45

Procedures.................... 46

Sample

Data Sources

Presentation of Data and Analysis

Limitations .................... 56 
Propositions for High Risk

Description of the Sample Population . . . . . . . 61

Student Perceptions of Educational Experiences . . . . . 84

Personal Identification

Curriculum and Organization

Educational Performance

School Status Perceptions

Transition from Regular to Alternative Program

VI SUMMARY, CONCLUSIONS, AND RECOMMENDATIONS . . . . . 111

How does the Alternative Population fit

Traditional Descriptions of High Risk?

How did the Students come to the Alternative Programs?

What Patterns can be identified from these Students'

Educational Experiences?

Conclusions . . . . . . . . . . 123

Recomnendations for Further Research . . . . . 126

BIBLIOGRAPHY . . . . . . . . . . . . 128

APPENDICES

A. Description of Alternative Programs Selected for the Study

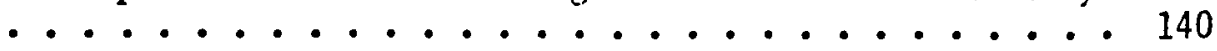

B. Sumary of Preliminary Pilot Study . . . . . . . 144

C. Student Interview Schedule, Consent Forms . . . . . . 155

D. Summary Description of Interview Group . . . . . . 164 


\section{LIST OF TABLES}

TABLE

$\underline{\text { PAGE }}$

I Male/Female and Grade by Program .......... 62

II Race/Ethnic Category by Alternative Program . . . . . . 64

III Free/Reduced Lunch Participation by Alternative Program - 65

IV Alternative Students' Entry Category by 1983-84

Grade Level . . . . . . . . . . . 66

V Entry Category by Alternative Program . . . . . . 68

VI Frequency of School Changes by Entry Category . . . . . 69

VII Duration Frequencies in Months by Alternative Program . - 70

VIII Duration in Months by Grade Level and Alternative Program 71

IX Alternative Program Students by 1983-84 Leave Codes . . . 72

X Alternative Students' 1983-84 Withdrawal by Grade Leve1 . 73

XI Frequencies of Grade Retention During District Enrollment 75

XII Achievement on Reading, Math and Language Tests . . . . 76

XIII Students with Suspension History by Alternative Program . $\quad 77$

XIV Frequency of Suspension by Offense Code . . . . . . 79

XV Number of Students With/Without Identification for

District Supplementary Programs ........... 81

XVI Frequencies of Identificaton for Special Education,

Chapter I and Other Alternatives by Program ...... 82

XVII Frequencies of Supplementary Program Participation . . 83

XVIII Comparisons of Curriculum and Organization: Regular and Alternative Programs ............ 87

XIX Differences Between Regular and Alternative Programs . . 90 
TABLE $\quad \underline{\text { PAGE }}$

XX Student Perceptions of Selves as Learners/Students . . 92

XXI How Alternative Students Feel About School in General . . 93

XXII Success in the Regular School Program . . . . . . . 95

XXIII Success in the Alternative Program . . . . . . 96

XXIV Relationships with School Staff . . . . . . . 98

XXV Relationships with Alternative Program Teachers . . . . 100

XXVI Extracurricular Participation in Regular and Alternative Programs ........................ 101

XXVII Grade Level of School Dropout by Alternative Program . . 102

XXVIII How Students Were Doing in the Regular Progran Before Alternative Entry ............ 103

XXIX Problems in the Regular Program Prior to Transition to

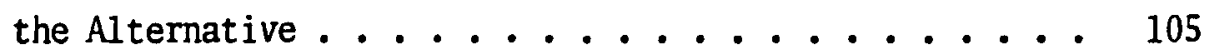

XXX Reasons for Leaving the Regular High School Program . . 106

XXXI Assistance in Transition from Regular to Alternative Program . . . . . . . . . . . . 107

XXXII Student Goals for Alternative Program Participation . . . 108

XXXIII Placement If Not Enrolled in Alternative Program . . . 110 


\section{LIST OF FIGURES}

FIGURE

$\underline{\text { PAGE }}$

1. Frequently reported personal/social and school-related characteristics of dropout populations . . . . . . 20

2. Frequently reported dropout characteristics and self-reported reasons for dropout ............... 24

3. Information provided by the student master file for each year of district enrollment ............ 50

4. Outline of design procedures, questions, data sources . . 55

5. Educational career experiences of $\mathrm{K}-2$ entrants to the district ...................... 119 


\section{CHAPTER I}

\section{INTRODUCTION}

A continuing high dropout rate is a problem for secondary schools. The magnitude of the problem is of concern educationally, socially, and economically. For fifty years, the phenomenon of the high school dropout has endured as a topic in educational literature. The focus of research on the dropout has been on population characteristics--social and school-related personal characteristics which have been variously interpreted as causes, as symptoms, and/or as predictors. In the sixties, a new perspective on the dropout phenomenon appeared in the literature. The focus on the dropout shifted from student population characteristics to the educational institution and the schooling process. Academic policy and disciplinary regulations were emphasized and the dropout's perception of his or her status in school was examined.

Within this literature the school is presented as a monolithic construct. Since the sixties, however, two major innovations have altered the regular school program offerings--supplementary and compensatory education and the alternative schools movement. Because of the development of compensatory and supportive educational programs in addition to regular school offerings, it is appropriate to reconsider the traditional perspectives on potential dropouts and it is reasonable to inquire whether that population has been variously 
identified by early participation in supplementary and compensatory programs, or whether this group has indeed "railen through the cracks": with its educational needs overlooked. If students in alternative high school programs for potential dropouts have participated in supportive programs, this information can provide a basis for examination of early identification of potential dropout/high-risk students, and can suggest how these treatments affected comnitment to the educational process and persistence in school.

Statement of the Problem

There is much controversy regarding the effects of schooling and non-responsive delivery of educational services to potential dropout/high-risk students. At the same time there is evidence that school systems perceived as monolithic and non-responsive are broadly and deeply diverse in terms of programmatic offerings to meet the special needs of these students.

Schooling for this population may not have been a monolithic educational treatment which appeared to ignore student needs. The design and delivery of supplementary educational programs clearly implies that regular school programs aze naturally extended to meet a variety of educationally-related needs, including those of potential dropout/high-risk students. Federally funded programs; delineation of rights to appropriate educational services; countless cormensatory, remedial, and support programs are typically provided to deliver instruction and related student services. It is reasonable to assume that a potential dropout/high-risk population has received such 
supportive assistance during some, if not all, of its school experiences. On the other hand, because of the requirements for participation in categorically-funded programs, this group may have been excluded because descriptions for students with more severely handicapping conditions were not congruent with elusively categorized descriptors for potential dropouts.

A comprehensive and comparative review of the three bodies of literature--dropout, supplementary/compensatory, and alternative schools studies--suggests startling similarity among descriptors for dropout populations, for students with special learning needs, and for potential or real dropouts who participate in public high school alternative programs. Population characteristics, low academic performance, and dissatisfaction with school are common signs of potential dropout and signals for possible entry to public alternative schools.

The research in all three areas seeks to isolate symptoms, predictors and causes of unsuccessful school experiences or dissatisfaction with regular educational offerings. This emphasis has been used to generalize group characteristics, and generalized population descriptors have typically supported varieties of ad-hoc programmatic responses; they have been less useful in supporting a system-wide response to the needs of potential dropouts. It is possible that what the literature onits--histories of educational treatments provided these students prior to alternative school entry--can provide insight into elements of more effective and enduring programmatic responses which are possible to implement throughout a 
district's educational program. An emphasis on educational histories of an alternative student sample focuses the study according to Blum \& Spangehl's theory of high-risk which "describes the individual students' attitudes and behavior in relation to the educational system by focusing on the probability of his or her academic success or failure, a sphere in which educators can have direct influence" (1982:5). This focus encourages identification of variables schools can reasonably be expected to impact--achievement, socialization and commitment to the educational process itself.

\section{Importance of the Study}

The reality of continuing high dropout rates suggests that ad-hoc responses are not enough to meet the needs of potential dropouts. A different perspective upon these students and their schooling experiences may suggest more useful and effective ways of meeting their needs. This study seeks to provide that different perspective; and to emphasize potential dropout/high-risk descriptors which can either be influenced by an educational program, or which may be useful in the design of responsive educational programs in both regular and alternative school settings. A conceptual framework was developed to structure the study. The framework consisted of 11 propositions drawn from the literature. The conceptual framework allows the study a focus not only upon personal/social and school-related characteristics which describe the student population, but also upon students' historical educational experiences within a school system. Within the conceptual framework, the guiding questions of the study were formulated: 1) How 
does the district's alternative high school population fit traditional descriptions of high-risk? 2)How did the students come to the altemative high school program? 3) What patterns can be identified from alternative students' educational experiences in the district?

A continued commitment to formal education in high school alternatives may be related to previous educational experiences, as well as to personal student characteristics, and patterns of those experiences may provide insight to meeting the learning needs of potential dropout/high-risk students.

Scope of the Study

The focus of this study is upon the potential dropout alternative student, and the alternative study sample was examined not only from the literature-derived descriptors of alternative high school student groups, but also in terms of supplementary/compensatory student characteristics and dropout group descriptors. The purpose of examining the alternative student group from this three-part perspective (in terms of personal and school-related characteristics) was to determine whether alternative students were identified for each group during their school years; whether they experienced a variety of supplementary educational treatments in the regular program prior to alternative high school placement; and whether students perceived relationships between elements of their regular and alternative program experiences.

The particular public alternative high school population selected for this study is one which may be characterized as "potential dropout" 
or "high risk" in terms of academic success or failure. The high school alternative sample identified for this study is from an urban school district, which has five full-time alternative programs for potential dropout high school students. The study is being conducted at a time when the district is addressing a variety of questions related to support and extension of alternatives as part of a system-wide response to what is considered a continuing high dropout rate.

The question of how students came to the alter-ative school is an appropriate one to guide the study. The questions for this study, however, are not limited to consideration of responses in terms of personal/social and school-related characteristics or of behavioral histories and verified dropout. The study questions emphasize the relationship between placement in the alternative and the educational programs and treatments which preceded that entry. This extended perspective may contribute to a more specific definition of the high-risk student, and may have implications for development of system-wide responses to meet those students' needs.

The study is organized in five chapters. Chapter I provides an Introduction. Chapter II includes a review of three related bodies of literature: dropout studies, supplementary/compensatory educational programs, and alternative schools studies. Chapter III describes the design of the study, methods and procedures used in data collection, presentation, and interpretation. Chapter IV presents a conceptual framework of 11 propositions for high-risk and describes the characteristics, educational histories of the alternative high school student sample as well as their perceptions of those experiences. 
Chapter V presents a summary, conclusions, and discussion of the students and their educational histories prior to alternative school entry. 


\section{CHAPTER II}

\section{REVIEW OF THE LITERATURE}

For the last half century it has been a goal of public schools to design and deliver educational services to meet the needs of all students in order that they may complete high school. High school completion is generally considered a measure of a successful public school educational experience, as well as a reflection of the institution's viability.

The dropout population, as well as the potential dropout and high risk group is the subject of an extensive and varied literature. Local school districts have developed specialized educational services to supplement regular school programs with the intent of strengthening this group's cormitment to staying in school until high school graduation (Jablonsky, 1970). Public school systems typically provide an array of formal educational services for the potential dropout/high-risk student. Efforts to sustain the group have been further supported by federal categorical aid for educationally disadvantaged students and those with special learning needs (Beebe \& Evans, 1981; Mertens, 1972).

Since urban school districts include diverse student populations with a broad range of educational needs, it is common to find extensive supplementary and supportive educational programs provided in addition to regular school programs. A regular program within a school system 
typically includes an elementary and secondary program, and some districts include intermediate or middle school programs to bridge the elementary-secondary transition. Supportive supplementary educational programs are provided at all levels in addition to the regular school program, so that potential dropout/high-risk students may participate in an educational experience that is both regular and supplementary.

Based on a twenty-year experiment within public school systems across the country, the alternative education approach has also been taken as a viable component of most urban educational offerings. Alternative programs (or schools) are often perceived to provide a last chance at achieving student commitment to high school completion in the public school system. Entry to, and participation in, an alternative public high school generally replaces the regular school program and supplants assorted supplemental programs.

Examination of three areas of educational literature--the high school dropout literature, supplementary/compensatory education literature, and the alternative schools literature--will serve to amplify the context in which the proposed study is being described. While each body of literature is important in its own right, the interrelationships among the three have prompted the rationale for this study. All three areas focus on an elusively-described public school population which is characterized chiefly in terms of high risk. The intent of this three-part review of the literature is to lay the foundation for construction of a conceptual framework within which to examine the educational experiences of one district's high-risk student population. 
Review of the Dropout Literature

The literature on the high school dropout is extensive--both in its chronology and in its broad topical range. The Education Index to Periodical Literature, from 1929 to the present, attests to the perseverance of the dropout phenomenon. Referenced under a variety of subject headings over time, specific themes have developed. The earliest literature aimed at determining the magnitude of the dropout problem. Since the forties, the literature has closely fallen into the four-part outline suggested by Beal and Noel (1980); identification of population descriptors, isolation of predictive variables to help identify potential dropouts, consideration of student/program fit, and, emphases on the role and responsibility of the educational institution.

While it is possible to follow the development of generai themes historically, there is overlap among them; nearly all dropout studies (even the earliest) conclude with recommendations for increased school responsiveness to curb early leaving (i.e., programmatic or institutional responses); every ten years, regular census studies provide analyses of numbers of high school dropouts (i.e., magnitude of the problem). Data sources for dropout studies are typically student cumulative records; recollections of dropouts; recollections of former teachers and counselors; comparisons of matched dropout-persister student groups.

\section{Magnitude of the Dropout Problem}

The earliest studies relied on census and school record data to calculate yearly percentages of dropout. In 1907, Edward L. Thorndike, 
under the auspices of the United States Bureau of Education, wrote "The Elimination of Pupils from School," a study based upon examination of school records for 1,000 students in grades six through eight up to the age of 18; the sample was drawn from 14 cities in the Midwest and East. Thorndike was interested in finding out how many students left school at each of the fourth through eleventh grade levels and in determining what proportion of each grade level was eliminated. He found that about seven percent of the total enrollment left, but that rate of dropout was additive through the grades; $26 \%$ of the seventh graders did not continue to grade eight; $32.5 \%$ of the eighth grade did not enter grade nine; 378 of the ninth grade students did not continue in grade ten; 29.48 of the tenth graders did not enter grade eleven; 33.38 of the eleventh graders did not enter grade twelve. The greatest elimination occurred at the end of grade nine. In 1933, K1ine repeated Thorndike's study and examined changes in national dropout rates. The junior high school organization had been introduced and $\mathrm{Kline}$ wanted to know if the institution of junior high schools had counteracted increasing dropout rates. While $\mathrm{Kline}$ found dropout rates were similar to those of previous years at the sixth through eighth grade levels, he noted proportionally greater rate increases occurring at the tenth and eleventh grades of high school.

Another frame of reference for considering the magnitude of the dropout problem is socio-economic. Greene (1966) reported that while dropouts are decreasing proportionally, more students are leaving high school; that frustration and failure in school deprive youth of incentives to succeed and therefore dropouts may be tracked into 
welfare programs; that there are few places for dropouts in society and in a world of work which requires increased skills. According to Greene, dropouts are a sign of a major educational as well as social failure on the part of America's schools.

Every ten years national studies based on census data provided by the Bureau of Labor Statistics monitor the magnitude of the problem by reporting job-related socio-economic correlates of high school dropout. Participation in high school has regularly increased since the 1900's; the proportion of youth of high school age (typically 14-17) enrolled increased from $11 \%$ to $94 \%$ between 1900 and 1978 . The phenomenon of the high school dropout remains a critical problem; proportionally, public high school dropout rates remain at about $15 \%$ (Grant \& Eiden, 1983). In the years 1970 to 1978, the percentage of dropouts among white male students increased from $6.3 \%$ to $9.6 \%$. During the same period, there was a smaller increase in dropouts for white females, while the proportion of black student dropouts decreased (Grant \& Eiden, 1980).

From Grant and Eiden's Digest of Educational Statistics (1983) these factors of dropouts are reported: $85 \%$ of the 1980 high school graduates not enrolled in college are reported employed in the civilian labor force; 63.78 of the $1979-80$ dropouts are similarly employed. It is important to note that these figures include persons aged 16-24, which extends beyond the typical high school age range of 14 to 17 . Employment information for an additional 76,000 dropouts is not included because this number represents fourteen- and fifteen-year-olds who dropped out but are too young to be regularly employed. 
Biddle, Bank, Anderson, Keats and Keats presented yet another societal perspective on the magnitude of America's high school dropout problem: "In American society today, the major institutional determinant of adolescents' activities is the school. When adolescents drop out of this institution idleness results. Neither the economy, the family, nor religious or recreational organizations provide structure for that idle time" (1981:117).

\section{Population Descriptors}

Historically, the style of the dropout literature has been descriptive. The earlier descriptors moreover, were most often drawn entirely after the fact of dropout. Demographic data in individual student school records were collected in order to produce a descriptive profile of the population. Sometimes, former teaching staff were surveyed for their recollections of the students. Later, survey techniques were used to gather information about the dropout's family-usually parental occupation and attained educational levels as well as dropout-reported reasons for leaving school prior to high school completion. Three categories of characteristics are most frequently reported to describe the dropout: a) personal and social characteristics; b) school-related academic characteristics; c) social/ psychological characteristics which describe the group in terms of social behavior in and/or out of school.

Personal and Social Characteristics of the Dropout Population. Personal and social characteristics of the dropout population typically include age/sex/ethnic identification, family mobility and socioeconomic status, and social-psychological descriptions of the dropout's fanily. 
Sixteen is the most commonly reported age for dropout (Cook, 1956; Snepp, 1953; Jablonsky, 1970; United States Department of Labor, 1960). Because a sixteen-year-old student is typically a tenth grader, some studies report the tenth grade as the most common year for dropout. Dropout between the ninth to tenth grade transition was noted as early as 1933 by Kline.

Typically, in both educational research and census studies, more males than females are reported as dropouts though the differences are not considered significant (Grant \& Eiden, 1980; Snepp, 1953).

A United States Department of Labor study (1960) which examined dropout profiles in seven communities nationwide, suggested that where minority populations are part of a school system, the minority child is over-represented in dropout groups. Kaplan and Luck's (1977) review of the sixties' dropout literature and studies of Berlowitz and Durand (1976) confirm this finding. In the Portland, Oregon Public Schools, minority ethnic groups have been consistently over-represented among early leavers; from 1977 to 1984 leaver rates for American Indians have ranged from $12.8 \%$ to $15.7 \%$; for Blacks from $7.7 \%$ to $12.4 \%$; for Hispanics from $9.3 \%$ to $16.7 \%$, while for Whites the range has been from 78 to 9.18 (Sexton, 1984).

High transfer is the most frequently reported family-related characteristic of the dropout group. Bledsoe (1959) found that of 247 dropouts, 35\% had attended more than one elementary school, while only 28 had attended a single elementary school. Mobility among schools during one's educational career is characteristic of dropout groups described by Layton (1953), Cook (1956), Cervantes (1965), Stroup and 
Robins (1972), Berlowitz and Durand (1976). Bachman, Green, and Wirtanen's (1971) longitudinal study of a group of 220 young men who had dropped out of high school reported on a typical dropout population which came from large families, often from broken homes with parents of low educational achievement. Lower levels of parental educational attainment were reported by Layton (1953), Evraiff (1957), Cervantes (1965), Scales (1969), Stroup and Robins (1972), and Kaplan and Luck (1977); a home life characterized as unstable was reported by Gragg (1949), as weak or broken by United States Department of Labor (1960), Cervantes (1965), and Bachman et al. (1971); and often of low socio-economic status (Bachman et al. 1971; Layton, 1953; Lichter, Rapien, Seibert and Sklansky, 1962; Scales, 1969; Stroup and Robins, 1972; Tesseneer and Tesseneer, 1958).

School-Related Characteristics. School-related population characteristics include information about a) achievement and ability, b) retention in grade, c) attendance, d) level of extra-curricular activities, participation, and, e) behavior and disciplinary problems in school.

The most commonly-reported characteristic for both real and potential dropout students is that, in general, they are low-achieving. Some studies refine the low-achieving label by identifying a frequency of failure in specific school subjects, or by calculating grade-level equivalencies which indicate that the group is two or more years behind in basic skills achievement. Reading is the specific subject most often reported to be the dropout's poorest subject. 
In 1938, Eels' national study of secondary school standards produced achievement information for a dropout group of 1,329 from an original national student sample of 19,732. Eleven percent of the 1,329 dropouts had been asked to withdraw by their school administrations due to their poor scholarship. Carlisle and Williams (1938) examined the average length of time a sample of 400 students remained in high school prior to dropping out and found that whether they remained for one semester or five semesters, dropouts typically had a mean cumulative grade point average of 1.4 , indicative of general low achievement.

Snepp (1953) collacted data on 254 dropouts in Evansville, Indiana schools for two consecutive years and found that in both years, the dropout group as a whole read below average; approximately $40 \%$ of the dropouts in both years were on the high school failing list. Cook (1956) compared a group of 95 dropouts with a group of 200 matched persisters in the Atlanta schools and found significant achievement differences on both 1anguage IQ and non-1anguage IQ with short form of California Short Form Test of Mental Maturity. A history of academic failure at the secondary level was noted by Schreiber (1964), Thornburg (1975), and Ross (1983). Of twenty dropout studies reviewed by Tesseneer and Tesseneer (1958), thirteen included low achievement as a key characteristic of students who leave school early. Sixty-eight percent of the dropouts included in the United States Department of Labor study (1960) were at least two years behind in basic skills achievement. The dropout group's low achievement in reading was noted by Conant (1961), Beck and Muia (1980). 
Among descriptors for the dropout population noted in a 1973 study by the Inited States office of Education (USOE) were general grade-level skills two years behind, and failing grades in two or more subjects. Young and Reich (1974) interviewed and studied records of 544 Canadian dropouts and found that the average number of credits attained by age 17 equalled 12.7, as opposed to a requirement of 21 for high school completion. Eighty-three percent of their sample were below their respective districts' achievement standards. Mahan and Johnson (1983) surveyed 155 dropouts from a suburban Chicago school district and reported student performance two years behind, failing grades, and a $90 \%$ eligibility rate for special programs or services to be characteristic of the dropout group.

Related to achievement (but reported less frequently) is the dropout's typical IQ or ability measure. Eels' (1938) longitudinal study of secondary school standards, based on a sample drawn from 198 secondary schools (both public and private) in 48 states and Washington, D.C., found that for the 1,329 dropouts from the original sample of 19,932 students, the dropouts' mean IQ was lower than that of the mean IQ for the entire sample. Both Gragg (1949) and Combs and Cooley (1968) reported that dropouts generally fell below normative means on verbal and group intelligence measures. Snepp (1953) found that $85 \%$ of the males and $73 \%$ of the females in his two-year study of 254 dropouts in Evansville, Indiana schools, were below average on the Otis Test of Mental Achievement. Jablonsky (1970) found that $70 \%$ of students with the highest attrition from high school have IQ's ranging from $80-109$; and that $80 \%$ of the boys and $65 \%$ of the girls have failed at least one subject. Voss, Elliott and Wendling (1966), attempting to 
differentiate between low-ability students in general and the dropout population specifically, constructed typologies of dropout and determined that those who leave high school earliest in their careers are more often the lowest-achieving students with low IQ scores. A Hawaii State Department of Education survey (1968) found only $47 \%$ of the dropout population to be academically at grade level; dropouts were typically low-achieving in grades 3 and 4 with a reported median IQ of 91 reported from the third grade IQ test adminstration.

When Evraiff (1957) compared a group of California students (who had previously dropped out of the regular high school and later re-enrolled in a continuation high school) with the regular school population, he found no differences in either their mental ability or vocational aptitude. Howard (1978) suggested that most dropout students have average IQ's and about $10 \%$ have the potential to attend college. Yaffee (1982) argued that dropouts generally mirror school district populations and include students at all ability levels.

While earlier studies (Cook, 1956; Kline, 1933; Thorndike, 1907) reported that dropouts were often older than their grade level peers, later studies explained this factor in terms of grade retention. Many dropout students are reported to have repeated one or more grades during their school careers, prior to dropping out entirely (Carlisle \& Williams, 1938; Gragg, 1949; Jablonsky, 1970; Kaplan \& Luck, 1977; Layton, 1953; Lichter et al., 1962; Scales, 1969; Stroup \& Robins, 1972; United States Department of Labor, 1960).

After low academic achievement, chronic poor attendance is the most frequently mentioned characteristic of the dropout population. In the USOE study (1973), absences exceeding ten days per year were considered 
generally indicative of the dropout group. Poor attendance is repeatedly a key descriptor (Berlowitz \& Durand, 1976; Cervantes, 1965; Hicks, 1969; Kaplan \& Luck, 1977; Layton, 1953; Lichter et a1., 1962; Ross, 1983; Stroup \& Robins, 1972; Tesseneer \& Tesseneer, 1958). Another characteristic of the dropout population is that dropout students participated in school activities very little or not at all (Cervantes, 1965; Gragg, 1949; Scales, 1969; Snepp, 1953). Livingston (1958) studied a matched sample of 173 graduates and 116 dropouts and found that participation in high school activities accounted for a third of the variance between the two groups.

A history of behavior and discipline problems is often reported for the dropout group (Beck \& Muia, 1980; Cervantes, 1965; Hicks, 1969; Kaplan \& Luck, 1977; Scales, 1969; Snepp, 1953). Strained relations with teachers are reported by McDill, Meyers, and Rigsby (1967), and Thornburg (1975). Snepp (1953) reported that school ccunselors judged $54 \%$ of the dropout population in his study to be socially maladjusted. Social maladjustment was a characteristic of $23 \%$ of the group studied by Young and Reich (1974). Cook (1956) described the dropout group as having poorer school adjustment than persisters, and Schreiber (1964) noted that dropouts tend to have typically low self-concept and social skills.

Bachman et al. (1971) characterized dropouts as a group with low aspirations; alienated as well as isolated from society; and typically rejected by teachers because of continuing academic as well as disciplinary problems in school. A third of the studies reviewed by Tesseneer and Tesseneer (1958) reported that dropouts had feelings of discouragement and non-belonging in relation to school; feelings of 
non-belonging were also reported by Cervantes (1965) and Ross (1983). Thornburg (1975) concluded that social problems were as pervasive as academic ones.

Figure 1 displays the most frequently cited descriptors, or dropout student characteristics, organized under two broad headings: personal/ social and school-related. The characteristics are listed in a descending rank order from more to less-frequently reported.

PERSONAL/SOCIAL CHARACTERISTICS

1. Frequent student transfers, mobility during school career

2. Low parent educational level (usually reported as father's)

3. Broken or weak home

4. Age 16

5. Feelings of nonbelonging toward school

6. Not interested in school

7. More often male

8. Low socio-economic status

9. Dislike teachers

10. Often minority

11. 01der than grade-level peers

12. Older siblings dropped out

13. Social/emotional problems; maladjustment; poor self-concept
SCHOOL-RELATED CHARACTERISTICS

1. Low achievement in general

a. Subject failure

b. Low reading ability

c. Two years behind in general

2. Attendance

3. Retained in grade

4. Lower ability measures

5. Non-participation in extra-curricular activities

6. Poor behavior/discipline problems at school

7. Suspended

14. Delinquency

Figure 1. Frequently reported personal/social and school-related characteristics of dropout populations 
Predictors for Dropout. Both personal/social and school-related characteristics are most often examined after the fact of dropout and generalized to group descriptors. Because much of the data are typically available in school records or observable in student performance and behaviors, a common use for the data is for prediction of dropout (Conant, 1961; Hicks, 1969; Johnson \& Hopkins, 1972; Layton, 1953; Lichter et al., 1962) and early identification of the "potential dropout" population. Low achievement, poor attendance, non-participation in activities, behavior problems, family mobility, low parental educational level, low socio-economic status, and a general non-interest in school (Gragg, 1949; Scales, 1969; Stoughton \& Grady, 1978; Stroup \& Robins, 1972) are typical predictive descriptors.

Layton (1953) categorized the common predictive descriptors according to four sources of dropout: (a) Student, (b) Family, (c) School, and, (d) Community. Low achievement, retention, excessive absences, a poor attitude and behavior problems were grouped under the student source. The family source included low socio-economic status, low level of parental education and a transient lifestyle. The school was cited as a source of dropout when it denied a functional curriculum and supported a purely academic one. The community source was described in terms of a perceived failure to involve social agencies in participative support for keeping students in school.

Hicks (1969) described dropping out as a predictable sequential process in which the characteristics or symptoms are reported behaviorally: Students (a) lose interest in schoolwork, (b) begin to get low grades, (c) start to skip class, (d) are involved in conflict 
with authority, (e) exhibit disruptive behavior, (f) experience suspension; $(\mathrm{g})$ when parents are finally called in, the atmosphere is one of "defensiveness," and (h) students quit. Hicks recommended that schools monitor the symptoms and thereby the dropout process, to gain information useful for responsive intervention.

Young and Reich provided a basic definition of real and potential dropouts as: "students who have exhibited poor attitudes toward school, have poor attendance, are failing subjects, lack credits, and are among the oldest at their grade level" (1974:1). In 1975, this general profile of a potential dropout was drawn by a report of the National Advisory Council on Supplementary Centers and Services: sixteen, male, tenth grade, low-achieving, retained in grade, failing, of low socio-economic status, with between twenty and thirty absences the previous grade, little or no extracurricular activity participation, often a minority student, disruptive, from a stressful family life, with a history of agency referrals, legal and economic problems, and, poor reading ability.

These generic dropout descriptors are reiterated in school district dropout studies (Gadwa, Bolck, Bryan \& Christensen, 1983; Los Angeles, 1982; Mahan \& Johnson, 1983). Correlations of typical dropout factors have been examined (Livingston, 1958; Lloyd, 1968; Rumberger, 1983; Urdahl, 1963) and used to predict future dropout rates early in the elementary years (Eeles, 1970). While prediction is based on assumptions of close correlation (and sometimes inferred causation) between student characteristics and the fact of dropout, some authors deny a causal relationship and question even the correlation between 
predictors and dropout. Cervantes (1965) pointed out that though there may be significant correlations identified among these sets of independent variables, such correlates do not establish a cause and effect relationship, but instead suggest a simultaneous occurrence which can usefully shed light on the nature and scope of the dropout phenomenon, and lead to consideration of probable success of various kinds of educational treatments one could employ to decrease dropout.

Self-Reported Reasons for Dropout. Interwoven throughout the dropout literature is a commentary by dropouts themselves reporting their stated reasons for leaving school. While some reasons reflect predictor characteristics, others refer to the students' perceptions of their social status within the school environment.

When one considers dropout-reported reasons for leaving school with population characteristics (be they interpreted as predictors or symptoms), there are few direct relationships among the data. Figure 2 describes self-reported reasons for dropout along with traditional descriptive characteristics. 
PERSONAL/SOCIAL CUAPACTERISTICS

1. Frequent student transfers, mobility during school career

2. Low parent educational level (usually reported as father's)

3. Broken or weak home

4. Age 16

5. Feelings of nonbelonging toward school

6. Not interested in school

7. More often male

8. Low socio-economic status

9. Dislike teachers

10. Often minority

11. 01der than gradelevel peers

12. O1der siblings

dropped out

13. Social/emotional

problems; maladjust-

ment; poor self-concept
SELF-REPORTED SCHOOL-RELATED REASONS FOR DROPOUT* CHARACTERISTICS

Dismissed for poor 1. Low achievement scholarship. Dislike in general subjects; failing a. Subject failure grades too far behind to catch up

Feelings of nonbelonging; lack encouragement to remain

b. Low reading ability

c. Two years behind in general

2. Attendance

3. Retained in grade

4. Lower ability measures

Dissatisfaction with school; lack of interest; negative attitude toward school

5. Non-participation in extra-curricular activities

Dislike students

Dislike teachers

6. Poor behavior/ discipline problems at school

Expelled; asked to leave

7. Suspension

Marriage/pregnancy

Desire for work; high

school organization

too demanding

14. Delinquency

Figure 2. Frequently reported dropout characteristics and self-reported reasons for dropout

* Snepp, (1953); U.S. Department of Labor, (1960); Thornburg, (1975); Oregon Department of Education (1980); Mahan \& Johnson, (1983). 
Sewell, Manni, and Palmo (1981) found weak and nonsignificant relationships among social, personality, vơatioñal and achievement variables, which led then to conclude that many personal characteristics of dropouts were, in fact, independent of persistence in school. The testimony of dropouts also challenged the correlational-causal assumptions. In 1956 Cook noted that population characteristics may be accurate descriptors, but of little use, since they have little impact on dropout if reasons for leaving school are otherwise, for example due to a desire for work, or to dissatisfaction with school. Cook urged that responsible reseach attempt a useful discrimination between symptoms and causes of dropout.

Cook described the dropout group as having poorer school adjustment than persisters, and Schreiber (1964) noted that dropouts typically tend to have low self-concept and social skills. Bachman et al. (1971) described dropouts as having low aspirations, low self-esteem, and feelings of alienation and social isolation. A third of the studies reviewed by Tesseneer and Tesseneer (1958) reported that dropouts often felt discouragement and non-belonging in relation to school. Feelings of non-belonging were also reported by Cervantes (1965), Easley (1971), Miller (1967), Ross (1983), and Thornburg (1975).

Lichter et al. conducted a longitudinal study which examined the psychological factors of dropout populations, and concluded that emotional problems impinge on school experiences to produce "a failure (not necessarily a matter of specific learning disability, but rather a broader 'educational disability'"' (1962:2). 
Many of the studies reviewed to this point conclude with recommendations for educational responses to counteract real and potential dropout. Both recapture programs (designed to gain back the population which left) and intervention techniques (aimed at keeping potential dropouts from leaving) take the form of high school curricular adjustments advanced to improve student achievement (Beal \& Noel, 1980; Brain, 1974). Replacing all or part of the high school program with a career emphasis (often work-study) is the most common specific curricular adjustment recommended (Beck \& Muia, 1980; Dauw, 1972; Kumar \& Bergstrand, 1979; Langsdorf \& Gibboney, 1977; Patterson, 1955). In addition to curricular responses, improved guidance at both elementary and secondary levels, and increased support for the elementary to secondary school transition are encouraged (Conant, 1961; Easley, 1971; Ross, 1983; Schreiber, 1964).

\section{Review of Supplementary Compensatory Educational Programs}

The War on Poverty legislation of the sixties provided significant impetus to development of programmatic responses targeted to a student population which typically included potential dropouts. The sixties legislation provided for two separate kinds of support: (a) communitybased programs aimed at improved skills and job training experiences, and, (b) funding for public schools' compensatory education programs which included not only provision for an appropriate basic skills supplement, but also for improved instructional practice to deliver those services. 
The War on Poverty legislation included various appropriations for programs classed under the Economic Opportunity Act which provided community support for dropouts most often by way of out-of-school education and training opportunities to prepare them for successful work experiences. Job Corps provided remedial basic education and training to youth aged 16 to 21 who had not completed high school and were unable to obtain work. The Neighborhood Youth Corps provided work experience for dropouts as an incentive to support their return to, or persistence in, formal educational programs. Community Action Programs supported tutorial methods for youth both in and out of school. The Manpower Act of 1965, operated through the state employment agencies, provided testing and counseling for out-of-school youth aged 16 through 22, and contracted with both public and private educational agencies to provide training responsive to current manpower needs. The Vocational Education Act of 1963 consolidated vocational education funds of prior legislation to support state plans for vocational education and to extend work-study opportunities for potential dropouts. All of these programs encouraged youth to remain in school or to attend special training sessions, based upon the belief that a continuing educational conmitment would increase one's likelihood of securing work and maintaining a job.

A large part of the literature on programmatic responses reflects the implementation of the Elementary and Secondary Education Act (ESEA) of 1965, particularly Title I (now known as Chapter I) which funded supplementary educational programs for the disadvantaged. In general, supplementary programs funded by Chapter I are designed to compensate 
or make up for presumed deficiencies in the learning experiences of socially and/or educationally disadvantaged children. Program goals aim to impact widening gaps in achievement between the disadvantaged and the advantaged groups as they move through the grades. The criteria for participation in ESEA compensatory programs closely matches descriptive characteristics of potential and real dropouts. Ornstein, Levine, and Wilderson (1975) explain that supplementary programs were implemented to respond to disparities between groups; to identify and effect the best educational practices to reverse those disparities. Compensatory educational programs center about assumed "deficit" characteristics of the disadvantaged. Many of these characteristics are the same as those used to identify real and potential dropouts.

The most frequent first step taken by schools to reduce the disparities of achievement is diagnosis of school-related characteristics, and presciption for program responses in terms of remediation in the basic skills. Most compensatory educational programs are implemented at the elementary level. Carter (1984) points out that there is no simple standard definition or description of compensatory education as it consists of various programs, practices and services which districts provide with the support of Chapter I funding. In general, the prograns have two emphases: a curricular emphasis on improved achievement in the basic skills, and an instructional emphasis based on more-personalized instructional practice and delivery. 
Questions asked about students identified for compensatory programs--why the disparities?, Are they reversible? How can we accomplish the reverse?--are virtually the same questions addressed by comnentators in the dropout literature (Why do some students drop out and not others? Can high school holding power be increased? What are the most effective means of counteracting dropout?). For both disadvantaged students and potential dropouts these questions are initially addressed by examining personal/social and school-related characteristics which are typically congruent for both the disadvantaged and the dropout populations. In 1968, the ESEA was anended to include Title VIII, Section 807 which funded Dropout Prevention Projects. Programs were targeted at 15 year olds or late junior high and entering high school studentis, and consisted of counseling and of ten work-study orientations, with occasional emphases on improved innovative curriculum and instruction. Nineteen public local educational agencies demonstrated innovative, supplementary programs to prevent dropouts in target schools. After four years implementation it was estimated that in the target schools, the dropout rate was reduced by 528 (Underwood, 1980).

Mertens (1972) found that while remedial programs may improve basic skills achievement, the remedial approach may not be the most efficient means of preventing actual dropout because, in his view, poor skills are not necessarily a primary cause of dropout; low achievement is but a symptom. Thornburg (1975) argued that high-risk students should not be classified in terms of cultural disadvantagement and compensatory educational programs because the group in question is not 
necessarily a "slow" learner group, but instead a group of "different learners."

In examining supplementary programs and their impact on potential dropout populations, Neill (1979) called for better articulation of all programmatic offerings to meet the needs of students failing in regular programs. Mahan and Johnson (1983) found that $90 \%$ of their dropout sample were eligible for special education programs or services and recommended an emphasis on district support programs to keep students in school. Berlowitz and Durand (1976) suggested that remedial programs, in addition to improving basic skills achievement, also seek to improve student self-concept and reduce absenteeism--all goals for programs for potential dropouts.

Opposing themes are identified in Ross (1983), who ruled out including students identified for special education services in supplementary interventions designed to keep students from dropping out, on the grounds that the special education group already receives appropriate attention within the school program. Mertens (1972) reported on an Arkansas Dropout Project and concluded that while some remedial support may help prevent early leaving, it may not be the most efficient means if poor student achievement is only a symptom and not a primary cause of dropping out. According to Mertens, ESEA Title VIII dropout prevention projects were based on needs assessments based on superficial theories of causality which do not provide a sound basis for building programs to meet real educational needs. 
Students and School Organization

Fenstermacher (1977) pointed out that the flaw in programmatic responses lies with their narrow focus; conventional education is less likely to attend to the nature of the interaction between students (with their multiple combinations of personal and school-related characteristics) and the high school bureaucratic structure. Instead of considering an emphasis on the relations between students and the organization, (briefly noted by dropout self-reports) schools typically attempt to impact only part of the problem--the students--without dealing with the broader implications of the student's interactions with the organization. Cicourel et al. (1963), in a study of organizational responses to student needs, reported that schools typically produce definitions of students which closely relate students' academic and personal problems, with the result that clear responsive educational treatments are obscured. Student problems are diagnosed as characteristics of student's personalities, and are not considered in relation to their educational experiences, even when the most frequent description of the problem is academic failure, which is produced via school instructional experiences.

Sewell et a1. (1981) critiqued the dropout literature in terms of its narrow frame of reference. Viewing the problem of dropout in terms of a match between school-related and personal/social characteristics and the traditional functions of high school is severely limiting, in their view, because it excludes a large number of dropouts who are able students and falsely assumes homogeneity in the dropout population. Their findings led them to suggest that a more appropriate research 
emphasis might be the secondary school process and its impact upon students. Among policies considered for re-examination were academic policies of tracking, and discipline policies related to suspension. Re-examination of traditional schooling practice emphasized alternative organizational settings for instructional delivery.

Tracking. The curricular policy of tracking (placing students in relatively homogeneous programs) is often considered in the dropout literature. Each level of education provides a kind of credential for the next level, and the process of identifying and selecting students begins early in the student's school career. Brookover and Erickson point out that students' assignments to various tracks influences "not only what the students learn but also their abilities to learn" (1969:37). A 1964 NEA study found that students enrolled in the regular general education track were estimated to have a $70 \%$ chance to complete their programs while students enrolled in a vocational track had a probability of graduating estimated at $50 \%$.

Combs and Cooley (1968) used school records data for a group who dropped out of the National Project Talent sample, and found that $73 \%$ of the male dropouts and $64 \%$ of the females were in the general curriculum track at the time of dropout thougn at high school entry only $25 \%$ of the dropouts were in that track. Schaefer and 0lexa (1971) pointed to "program and process" in their study of two midwestern three-year high schools in which students were tracked into either college-preparatory or non-college-prep programs. After personal and school-related characteristics (father's occupation, student achievement and a measure of intelligence) were controlled, the 
non-college-prep track students had higher rates of academic failure, noninvolvement in extra- curricular activities, misbehavior, and a chance of dropout nine times greater than that of the college-prep track group.

In both Schaefer and 0lexa and also Hargreaves (1967), a student's academic status in a track was correlated with forms of school avoidance, student misbehavior, and an erosion of student self-esteem. Kelly and Pink (1973) concurred; high-risk students may not have a legitimate status in the school organization, and tracking practices could increase the probability of failure for some of them. Kelly and Pink found that a student's track position in school was a stronger indicator of his commitment to school than his socio-economic status; that more students with positive high school status have positive feelings about school and about themselves as learners; that more are likely to be involved in extra curricular activities, and that more aspire to continued education. Arnove and Strout (1980) suggested that compensatory treatments may in fact have supplanted instead of supplemented the regular school program, and produced an entirely new track for the disadvantaged and the potential dropout population.

Discipline Policy. Suspension and expulsion policies are frequently examined in relation to dropouts. According to Berlowitz and Durand (1976), a dropout may be better described as a "pushout--the student, who through discriminatory treatment is excluded from school or else is so alienated by the hostility of the school environment that he or she leaves" (1976:1). Berlowitz and Durand suggest that suspension and expulsion regulations contribute to dropout, when the 
lack of educational opportunity which results can be directly related to a student's lack of success which leads ultimately to his total exclusion from school. The Berlowitz and Durand theory was based upon percentage analyses conducted by the Children's Defense Fund of Washington (1974) which pointed out that poor, minority, and working-class children are disproportionately represented among public school dropout populations, and thereby virtually excluded by practice and policy from success in public schools.

\section{Review of Alternative Schools Scudies}

While traditional organizational responses may not appropriately meet the needs of the potential dropout/high-risk group, alternative schools studies suggest an institutional response which may have been more successful. Much of the literature describing institutional role and responsibility for dropout is closely associated with alternative schools studies; in addition to its emphasis on more personalized curricular design and instructional delivery, the alternative schools literature considers effects of non-traditional organizational structures, policy and regulations. The public schools' contribution to the development of alternative schools and programs has been significant, both in support and design of recapture and intervention treatments which have typically been implemented at the junior high and/or high school level.

A co-focus of the $1960^{\prime}$ s federal educational legislation led to the development and proliferation of alternative schools in public and private educational settings. In the late sixties and early seventies, 
to respond to continuing high dropout rates and inability to meet the needs of education for adolescent populations, a number of national commissions reported on ways school districts might respond to the problems of youth. One of the most frequent suggestions was establishment of alternative schools and programs in addition to the conventional high school program (Brown, 1973).

Deal (1975) describes the alternative movement as a departure from the status quo of conventional schooling on six dimensions: (a) roles of those involved in the learning process, (b) curriculum, (c) teaching methods, (d) authority and decision-making about what is to be learned, (e) location, and, (f) time frame in which the learning occurs. Raywid (1983) cites six elements which distinguish alternative education: (a) distinct and identifiable administrative unit, (b) emphasis on improved school climate, (c) participation by choice, (d) responsiveness to particular unnet needs, (e) an impetus from its clients, and, (f) attempts to address broader student development than merely the cognitive.

In describing the early years of alternatives, Riordan (1972:9) states that their development was enhanced by their attention to the "complex political and pedagogical issues" which confront all schools. Tyack (1974) pointed out one common pedagogical issue which alteratives subscribed to was a consensus that differing learning experiences could better meet differing learning needs. Smith (1973) noted a common political issue alternatives shared: that educational options in general, and alternative programs in particular, provide a means of making education more responsive to students and parents, and that the 
opportunity to choose among options enhances one's commitment to education. Concern for meeting differing student needs was the pedogogical impetus for the design of public alternative schools. Discontent with traditional schools provided a political impetus for their creation (McCauley \& Dornbusch, 1978).

In general, two distinct kinds of alternatives have been developed in public schools. Each meets the needs of a different student population. Raywid (1981) describes the generating factors for development of the two types of alternative schools: (a) response to student needs for challenge and diversity, which may be described in terms of educational improvements and systems reforms, and (b) responses to particular problems such as those of truant and potential dropout populations, which may be described as systems-serving. While both kinds of alternative programs and schools share many basic characteristics in their approach, the description of their populations varies significantly; the former definition calls for a student population with a strong commitment to education in general, coupled with a desire for more appropriate learning environments; the potential dropout lacks the same kind of commitment and typically does not ascribe value to the schooling process he has experienced. While the former student groups may be more academically able (though they may choose not to participate in school), potential dropouts are generally less successful in accepting and meeting the demands of a regular school program.

Smith (1973) found that at least a third of the nation's approximately 1,500 school systems operate one or more alternatives. 
Usually small in size, and located at the secondary level, alternatives extend in range from upper-class college preparatory to magnets for curricular specialization to special interest schools and programs which attempt to meet the unmet needs of students typically described as marginal, resistant, or high-risk. Arnove and Strout (1980) and Raywid (1983) estimate that about a third of all alternative programs and schools are targeted at high-risk student populations.

A variety of alternative programs and schools for the high-risk population are reported in the literature. Opportunity Industrialization Center (OIC) programs provide a career decision-making orientation through counseling, career investigation, basic skills instruction related to career explorations plus hands-on work experiences (Gibboney, Langsdorf \& Smith, 1975). GED programs are also popular bases upon which to build supportive alternative re-entry programs (Harris, Fields \& Carter, 1983). Beach and Halverson (1981) found that public school alternative programs and schools in New York were most effective in terms of remediation in basic skills, provision for enhancing commitment to stay in school, and in providing opportunities for work experiences for their high-risk populations. When students required, or elected to acquire services outside the public school system, Beach and Halverson found fewer programs with equally effective elements.

The alternative schools' literature suggests that the organization they provide is one in which individual students can easily acquire positive status within their more flexible, informal organization, and, with the support of caring teachers, achieve the status necessary to 
have a successful school experience. Participation in an alternative operationalizas the system's flexibility in the eyes of the high-risk students, and allows for greater academic success which in turn can increase commitment, and positive attitudes, and decrease disruption and delinquency.

A more open and flexible setting defines the alternative environment, and both students and teachers perceive that they are able to exercise a degree of autonomy impossible to achieve in a more traditional setting (Nirenberg, 1977). A nurturing quality of the alternative school environment is reported by Bredemeier (1968) who notes that student growth of a more holistic nature (including more than the cognitive dimension) is the goal of alternative practice. Mann and Gold speak to the personalized quality of alternative education: "From curricula whose level and pace meet students at their current level of academic adjustment and achievement; and from teaching styles that convey a sense of personal caring and support" (1981:15).

Research on organizational variables and decision-making capabilities of alternative school students and staffs has led to conclusions about the importance of ownership and participation (Duke, 1978); of alternative school climate (Gowan, 1971; Kaplan \& Luck, 1977); and to support for the perception that student attitudes toward schooling are uniformly more positive in alternative settings (McPartland \& Epstein, 1977). Their smaller size, flexible scheduling, relaxed rule structure and quality of teacher-student interactions have been reported to produce a positive environment for learning and far fewer behavior problems (Bredemeier, 1968). Emphasis on counseling, 
flexible scheduling, and work-study are typically cited as popular elements of alternatives (Abel, 1970). Organizational models are extensively described in the alternative schools literature; schoolwithin-a-school models (Nelsen, 1975), recapture programs (Altbuch \& St. George, 1981; Ross, 1983), and separate and unique programs (Smith, Barr \& Burke, 1976) are among the most conmonly-reported.

Ghory and Sinclair (1978) chronicled the development of alternative schools for a high-risk student population and hypothesized that these groups perceive and internalize the mismatch between themselves and the traditional educational process. They recognize that they are incapable of success within regular school programs, so that they avoid a commitment to the schooling process, either by continuing their attendance but effectively tuning out, or by taking the final step and dropping out.

As alternatives respond to specific learning problem areas, and within different environmental settings, they have extended the compensatory effect of more traditional supplementary programs. Raywid's (1983) national survey of alternative schools and programs indicated that $79 \%$ of them include basic skills development as a primary goal. They have provided a consistent supportive environment for learning in which students may receive remedial training throughout their schooling experiences, as opposed to participating during selective pullout educational programs. In terms of instructional practice in alternatives, Bredemeier (1968) states that practices are common to the regular school program as well, but in regular schools they are practiced less consistently and with less concentration. 
Barr, Colston and Parrett (1977), in a survey of alternative program evaluations, concluded that achievement is typically the same or better in terms of grade point average and basic skills gains; that attitudes toward school, teachers and the learning process are typically more positive; and that attendance improves and behavioral disruptions decline. For the long term, these results suggest positive preparation for either a continuing educational commitment or responsible work practice. McPartland and Epstein (1977) concur that negative perceptions for schooling are slowed, and improved commitment results as a result of the alternative school experience.

Studies of educational alternatives for dropouts with related behavior and delinquency problems are frequently reported. Gold and Mann (1982) studied a group of alternative students with severe behavioral problems including chronic truancy, disruption and delinquency. Their alternative program was designed according to the assumption that student academic success is central to enhancing self-esteem, that negative school experiences can provoke delinquency, and that a school which provides academic support as well as close teacher-student relationships can lead to improved success in school and from there to improved behavior. Gold and Mann distinguished between their population in terms of the severity of their problems and concluded that students who were less-anxious and less-depressed (even though they were aware that they were perceived negatively within their school system), were able to ignore their concerns by concentrating on their successes in the alternative setting. In that setting, their self-concept for learning was enhanced and their achievement and 
behavior improved. Gold and Mann pointed out that student successes (in terms of renewed commitment to education and learning) and improved behavior were achieved more because of the school's responsiveness than because of the characteristics of the student population. Altbuch and St. George (1981) reported positive effects of an alternative elementary program for delinquent youth. The disruptive behavior of delinquent youth drew attention away from their academic deficiencies and underlying frustrations. The alternative program dealt "specifically with this recognized but unclassified population, who would normally fall through the cracks of the educational system or be incarcerated in residential facilities" (1981:227); achievement increased and behavior improved.

Because the term "alternative" is often associated with programs for groups of less-successful youth or problem students, in some instances a stigma results which influences institutional support for programs and denies appropriate student access to the program (Arnove \& Strout, 1980). Referring schools may then classify alternative programs in terms of their general perceptions of students who attend (McPartland \& Epstein, 1977) before it is clear what aspect of each alterriative setting really benefits its clients. When dropout is accepted as a school system failure, "the responsibility resides with the school system to find educational treatments which will meet the needs of diverse populations" (McPartland \& Epstein, 1977:32). Whether this has been the premise upon which alternatives were founded is questionable; that they are producing the desired effect with potential dropout students is a reality. 
Arnove and Strout (1980) reported a concern that the special setting of an alternative for high-risk students can lead to their social isolation within the larger school system and can result in an alternative track which may not be in the best interests of the high-risk population. They suggest that the process of tracking reinforces social distinctions and is counterproductive. Therefore, the notion of choice, so critical to the rationale of alternative school development, has limited possibilities. One could reasonably conclude that alternative programs produce their own kind of tracks; that student self-selection or referral to an alternative in effect denies equal kinds of learning opportunities. The fact that participants in such programs attend them with more frequency, with less disruption, and with increased achievement seems to imply that students' acceptance of the alternative, though it be a track, is still perceived positively, and as a viable structure in which to learn, meanwhile reinforcing a student's continuing cormitment to the educational process. Blum and Spangeh1 (1982) argue that such tracks may be both appropriate and effective for high risk student populations. Arnove and Strout (1980) also posed the question of what impact alternatives have had on the educational system of which they are part. They suggest that it is conceivable that alternative schools may have positive outcomes in terms of attendance, achievement behavior and persistance rate, while the regular program may continue to suffer with all three problems for, "as soon as one group of dissident and disruptive students are channeled to alternatives, other students are likely to replace them within the conventional school system" (1980:30). 
Barr (1978) regards the alternative schools movement as a major reform strategy for innovative and responsible practice within an otherwise remarkably "monolithic" delivery system. There are always questions about whether students in different alternative programs are much the same, and about the efficiency of different programs themselves; Barr has written that "The most crucial issue as far as choice is concerned, is that various options be different from one another and from the comprehensive school program available in a given school district. This demand for distinctiveness is often missing in options school prograns.", (1978:13). Duke (1978) studied 40 alternative schools and found their organizational dimension to be more significant than either their pedagogy or their student achievement outcomes. He concluded that "contemporary alternatives constitute a direct challenge to the way schools have been organized and administered" (1978:41).

School districts organize in order to provide students an intelligible and rational progression through their public schooling. Resource constraints may not allow for uniform service delivery to all students at all organizational levels, but, there may be common educational experiences in regular, supplementary, and alternative programs which serve to strengthen a student's commitment to school. 


\section{CHAPTER III}

\section{METHODS AND PROCEDURES}

This study employs elements of naturalistic inquiry to describe how students within a district's regular program came to the alternative setting. The study begins with formulation of a conceptual framework describing potential dropouts; a framework which was developed from three bodies of literature reviewed.

Data were collected to determine the viability of the framework for describing an urban district's alternative high school population, and to produce a description of an alternative student sample and their educational experiences within a school district. Educational histories prior to alternative school entry were traced through district records and documents for a sample of 757 alternative high school students. Focused interviews were conducted with 81 students from the study sample to obtain student perceptions on their regular and alternative educational experiences within the district. An analysis was conducted for the purpose of describing 1) how a district's alternative high school population fits traditional descriptions of high-risk, 2) how the students came to the alternatives, and 3) to identify possible relationships between regular and alternative educational experiences. 
Research Design

This study is an exploratory one which has used some of the methods of a naturalistic inquiry. One goal of naturalistic inquiry is to increase the understanding of complex issues by 1) clarifying and better defining them, 2) investigating related perceptions of those issues, and 3) generating data to support their further study (House, 1980; Stake, 1976). The method of naturalistic inquiry is often described as an "inductive process" which begins from an initial framework and goes on to the development of guiding questions (Babbie, 1975; Wolf \& Tymitz, 1977). These preliminary steps serve to focus and bound data collection procedures, and provide a structure for analysis as well (Guba, 1978).

Because complex issues often occur over time, data collected may be retrospective and procedures may work backwards from the present (House, 1980). While naturalistic studies often include descriptive statistics (sometimes with attention to trends or patterns), more often data collected are qualitative and require descriptive analyses (Bogdan \& Biklen, 1982). If the preliminary steps of naturalistic method have been followed, the analyses respond to the guiding questions and thereby amplify the initial framework which structured the inquiry (Guba, 1978; House, 1976).

Wolf and Tymitz (1977) state that naturalistic inquiry begins with an initial framework which is reworked inductively throughout the process of data collection. The Chapter II review of literature described alternative high school students, students in supplementary/ compensatory programs and potential dropouts in remarkably similar 
terms. The similarity extended beyond student characteristics, to descriptions of common programmatic responses provided by schools. Observation of the educational programs available in an urban district indicates a diversity among program offerings in addition to the "regular" school program. While both the literature and observations suggest the possibility of relationships between regular and alternative experiences, studies have not focused on relationships between students' historical educational experiences in regular and alternative programs. Within the district selected as a site for this study, data regarding potential dropout/high-risk alternative students have not been previously examined. Therefore, a preliminary step sometimes used in naturalistic studies--the development of a conceptual framework--is a useful way to approach the investigation of those students and their educational experiences.

\section{Procedures}

In order to systematically proceed with this investigation, group characteristics and related school responses described in all three bodies of literature were summarized and organized into eleven propositions. These propositions served as a conceptual framework which guided the data collection, presentation and analysis. If alternative students were identifiable in terms of supplementary/ compensatory characteristics, and dropout characteristics as we1l, one would expect to find a history of responsive educational treatments provided these students beyond the regular school program and prior to alternative entry. An interview was designed for alternative students 
with the longest tenure in the school system, in order to collect their perceptions of their educational careers in both the regular and alternative setting. The presentation and analysis of these historical data were expected: 1) to explain how students came through the regular program to the alternative school, and 2) to identify ways in which these data can be useful to inform a school system's response to the needs of potential dropouts.

In order to pursue the question of how students came to the alternative, a preliminary pilot study was conducted to determine who the alternative students were in terms of characteristics, and how long they had been in the district; if the group entered the school system during high school, neither characteristics nor earlier educational experiences could be reliably traced. A second reason for the pilot study was to identify which characteristics were consistently reported for each year of district enrollment. For those variables not reported in the Student Data Base (for example, socio-economic status), other district information sources were accessed. If none were available (for example, the stability of home life) an interview question was written in order to capture the information at least for the interview subsarmple.

The historical data collection worked backwards from the 1983-84 alternative program enrollment. Records for each active/inactive student were produced for 1983-84, and for each previous year of enrollment back to a student's first entry to the district. Data were summarized for each of the five alternative programs in the study, and also in terms of four district entry categories (K-2 primary; 3-5 
elementary; 6-8 middle; 9-12 high school). An interview was conducted with students who had been enrolled in the district since their primary years; the interview questions paralleled the historical data collection, and worked backwards from the context of the 1983-84 alternative program.

Without a formal hypothesis to test, the investigation was open-ended both in terms of identification and selection of historical data. Nevertheless, both proceeded according to a set of specific propositions drawn from the literature review, and with an emphasis upon those variables a school system may reasonably be expected to effect. Before constructing formal hypotheses regarding early identification of potential dropouts by participation in supplementary/ compensatory and alternative programs, it would be necessary to determine if a sufficient literature-related description was available within students' historical records, and if there were identifiable patterns among the data to suggest the potential for addressing a specific hypothesis regarding the population.

Sample

Five alternative high school programs within an urban school district were identified for the study. The five were selected based on their legitimacy within the system, as evidenced by their support by the district general fund, and evaluations which have been conducted to determine program outcomes and effects. Each of the five is an example of an alternative school model defined in the literature. One is a continuation school which provides "for students whose education has been (or might be) interrupted" (Smith, Barr \& Burke, 1976). Another 
is a separate and unique continuous progress school with a vocational curriculum. The remaining are schools-within-a-school. A description of the five programs and schools is in Appendix A.

The study sample included 757 students, active and inactive, grades 9-12, enroiied during 1983-84, in the five alternative programs. The total $\mathrm{N}$ were examined in relation to characteristics of high risk-personal/social, school-related, and supplementary program participation. A sub-sample of 81 students were interviewed. During the fourth quarter of the 1983-84 school year, a list of actively enrolled alternative program students was requested from the district Data Processing department. Data Processing history tapes were examined to identify which of the actively enrolled students had entered the district system during primary years $\mathrm{K}-2$. Lists of names of active $\mathrm{K}-2$ entrants were distributed to alternative program directors to confirm each student's fourth quarter enrollment status. Letters were sent and telephone calls were made to both students and parents requesting permission for (and agreement to participate in) student interviews. Eighty-one alternative students responded and agreed to participate in the interview. It is important to note that two criteria for interview were 1) entry to the district at $\mathrm{K}-2$; and 2) active enrollment in the alternative program during the fourth quarter of the 1983-84 school year.

\section{Data Sources}

Five major data sources were accessed for this study: 1) District, Special Instruction, and District-Wide Programs documents and records, 2) Student Master file, and Master Course Directory, 3) Management 
Information Service documents and records, 4) Department of Research and Evaluation Test Data Base, 5) Focused interviews conducted with a sub-sample of 1983-84 alternative high school students who had been in the district since $\mathrm{K}-2$.

District Documents. The Policies and Regulations Handbook provided definitions and policies and regulations regarding Special Education, Chapter I, and alternative services and programs. Documents from the Department of Special Instruction provided a description of Special Education services available to district students, and interpretation of service-provider codes. District-Wide Programs Documents provided descriptions of alternative schools and programs available to district students; additional information and evaluations of those programs were examined in reports produced by the district's Department of Research and Evaluation.

Student Master File. The Student Master File contains information by student identification number for each year of district enrollment. For this study, the Student Master File was accessed to identify the 1983-84 active and inactive population of the five district alternative programs, and to trace historical enrollment information for the total sample. Figure 3 displays information for each student for every year of his or her enrollment in the district.

\begin{tabular}{|c|c|c|}
\hline lemograjhic & Mluress/Ianrol Iment & $\begin{array}{l}\text { Supplanent ary } \\
\text { Prouram }\end{array}$ \\
\hline $\begin{array}{l}\text { Stwent juentification } \\
\text { number } \\
\text { Stwlent nane } \\
\text { Sex } \\
\text { lithuic Category } \\
\text { Dilte of birth }\end{array}$ & $\begin{array}{l}\text { Ailuress } \\
\text { Entry/leave cole } \\
\text { and dates } \\
\text { Grade level } \\
\text { Scliool }\end{array}$ & $\begin{array}{l}\text { Special flucation } \\
\text { Disposition } \\
\text { Chnpter I }\end{array}$ \\
\hline
\end{tabular}

Pigure 3. Infonitition provided by the Stindent Mhister file for eilcli year of district enrollment 
The supplementary educational treatments examined in this study were those offered formally and provided district-wide: Chapter I, Special Education, and other alternative programs. Only programs designed to provide service to identified high-risk populations with corresponding entry requirements based on stated criteria were included. Regular school electives were not considered in this study; nor were the wide variety of programnatic specializations which high schools develop to enrich, expand, or reinforce their regular program offerings. Two assumptions of this part of the study were (a) that students identified for supplementary services did exhibit an educational need for the service, and (b) that supplementary programs followed procedures according to established criteria for participant identification.

A limitation of the Student Master File data was that while participation in Special Education requires extensive and systematic screening procedures, participation in Chapter I is largely based on low achievement score and/or teacher judgment. The Student Master File does not indicate which criteria were used for Chapter I identification.

Management Information Services. The Office of Youth Services Suspension log (maintained by Management Information Services) provides numbers, reasons for, dates of student suspension and re-entry for individual students. The Log includes descriptor codes for five general Reasons for Suspension: (a) Attendance, (b) Behavior with other students, (c) Behavior with staff, (d) Unacceptable individual behavior, and, (e) Criminal behavior.

Management Information Services Enrollment Reports from 1972 through the present chronicle school building code changes, school 
closures, and in-building grade level organizational changes.

Department of Research and Evaluation. Student achievement on district basic skills tests is recorded on the Department of Research and Evaluation Test Data Base.

Identification numbers of individual students in the study sample were entered into the Test Data Base to produce achievement scores for mathematics, reading, and language usage. Achievement scores are obtained from district-wide administered tests given fall and spring of each year for grades 3-8. Scores were associated with each study sample student's record.

In the fall of 1983, a preliminary pilot study was conducted which verified the accessibility, validity, and usefulness of information provided by the data sources. The pilot study is described in Appendix B.

Interview. An informal, structured, but open-ended interview was designed for use with a sub-sample of actively enrolled alternative students, who had spent the majority of their educational careers in the district. The purpose of the interview was to elicit student perceptions of their educational experiences in the district and their impressions of the circimstances which led to their entry to the altemative programs. Bogdan and Biklen (1982; 59) suggest that an interview is particularly fitting for a study emphasizing interactions of a group with an educational institution over time. Eliciting student perceptions of their educational experiences supports sustained attention on a school system's responsiveness to individual student needs. 
Questions for the interview were designed to elicit student perceptions of their educational experiences in terms of the student's academic and social attitudes and behavior in both regular and alternative programs. The interview also addressed the guiding question of how the students came to the alternative school.

Alternative school directors or principals reviewed the interview schedule. The researcher arranged for a limited field-test in the spring of 1984. Seven high school students in attendance at two private alternative schools in the area participated in the field test. At the end of each hour-long interview, the students gave the researcher their impressions of the format, content, and language used to state the questions. A follow-up group discussion was conducted with the first three field-test participants. As a result of the student comments, some language was adapted to reflect the cormon student vocabulary and questions which produced repetitive responses were deleted.

Directors of the five alternative schools in the study sample distributed parent/guardian consent forms to students who were identified for participation in the interview. Four of the schools distributed the consent form and explanatory cover letter on their own stationery. Students at the fifth school received the information by mail from the researcher.

The interviews were conducted during school hours in a separate room at each of the five alternative schools selected for the study. Prior to each interview, the consent form was read aloud and students were encouraged to ask any questions about the interview procedures. 
Consent forms were signed by student interviewees. The researcher read each item on the schedule during each interview, and student responses were written verbatim. Where probes were used, their wording was recorded. When students volunteered information beyond a description of educational experiences, comments were not recorded. Average interview time was forty-five minutes per student. See Appendix C for a copy of the interview schedule, explanatory letters, consent forms.

\section{Presentation of Data and Analysis}

The propositions of high risk were re-stated in a series of related questions. Data from school district records and documents were collected for each series of questions, and arranged in cross-tabulated frequency distributions and percentages to serve as responses to the study questions in terms of the total study sample $(\mathrm{N}=757)$. A Statistical Package for the Social Sciences (SPSS) program provided most frequency distributions and cross-tabulations; when data were manageable, distributions and cross-tabs were done by hand. Dataresponse displays were analyzed according to the propositions for high risk.

Interview responses were summarized according to the alternative students' experience-based perceptions of their academic and social performance and status in both regular and alternative educational programs.

Figure 4 outlines the inquiry process from literature review to conceptual framework, related questions and identification of data sources. 


\section{Limitations}

While many studies examine inter-related variables of dropout to isolate the cause of dropout, this study does not. The study is an attempt to examine a complex issue from a different perspective--in order to encourage identification of specific school-related descriptors which can be impacted to reduce dropout. Nor is this a conventional study of dropouts; many students in alternative programs may have dropped out of school for some portion of their high school careers, but during 1983-84, the study sample students were enrolled in district alternative programs and schools. This particular group of students, therefore, is not necessarily representative of those who have departed from formal public education with no intention of returning. However, if the study sample conforms to traditional descriptive characteristics it is representative of potential dropout/high-risk populations.

It is important to note that while the study has been guided by elements of naturalistic methodology, it does not conform precisely to any specific set of naturalistic "rules." Key elements of naturalistic inquiry contributed to the research design. For example, the researcher sought a perspective on a complex issue (dropout) to increase understanding of the issue and clarify the population characteristic needs upon which educational responses are built. The study did not proceed from a theory, but the presentation and analysis of data can be useful to generate or support extant theories about the dropout. 


\section{CHAPTER IV}

\section{FINDINGS}

The findings are organized in three parts: (a) presentation of a conceptual framework, b) description of the potential dropout population according to propositions drawn from the literature, and (c) sumnary of student reflections of the regular and alternative educational experience.

\section{Conceptual Framework}

A11 three bodies of literature report similar characteristics for potential dropouts, participants in compensatory and supplementary educational programs, and alternative school students. However, in order to provide more than a traditional needs assessment-perspective in terms of generalized population descriptors (upon which the school has little influence), an investigation of educational experiences (including student perceptions of those experiences) which emphasize factors the school can either respond to or directly influence must be examined.

Blum and Spangehl (1982) suggest that this approach considers students less according to deficit characteristics and more in terms of "high-risk," a term which "describes the individual student's attitudes and behavior in relation to the educational system by focusing on the probability of his or her academic success or failure, a sphere in 
which educators can have direct influence" (Blum \& Spangehl, 1982:5). Variables which underly the notion of high risk include cognitive ability, task motivation and performance, locus of control, and self-esteem. Cognitive ability is typically defined in terms of achievement. Task motivation and performance links learning tasks to individual students in terms of socio-cultural experience combined with abilities. Blum and Spangehl suggest that students need to understand their abilities in order to inform self-concept and to obtain that sense of control which will support their active participation in learning experiences.

Student characteristics and related school responses described in each of the three bodies of literature were summarized and organized into eleven propositions which served as a conceptual framework and guided the statement of orienting questions, data collection procedures and analysis.

Propositions for High-Risk

According to propositions drawn from the literature, one would expect that students enrolled in programs for potential dropouts would:

1. Have an experience of drop out at age 16, at grade ten, or at the transition period between elementary and high school (Cook, 1956; Hawaii, 1968; Snepp, 1953; U.S. Department of Labor, 1960).

2. More often be male (though there are not significant differences in numbers of males and female dropouts) (Grant \& Eiden, 1980; Snepp, 1953). 
3. Include an over-representation of ethnic and racial minorities (Berlowitz \& Durand, 1976; Kaplan \& Luck, 1977; Sexton, 1984; U.S. Department of Labor, 1960).

4. Have a history of high transfer/mobility among schools both within and between school districts (Berlowitz \& Durand, 1976; Bledsoe, 1959; Cervantes, 1965; Cook, 1956; Layton, 1953; Stroup \& Robins, 1972).

5. Be from families of lower socio-economic status (Bachman et al., 1971; Layton, 1953; Lichter, et al., 1962; Scales, 1969; Stroup \& Robins, 1972; Tesseneer \& Tesseneer, 1958), whose family life may be characterized as unstable, weak or broken (Bachman et al., 1971; Cervantes, 1965; Gragg, 1949; U.S. Department of Labor, 1960).

6. More often be lower-achieving in terms of reading (Beck \& Muia, 1981; Conant, 1961), in terms of being two or more years behind in basic skills (Mahan \& Johnson, 1983; U.S. Department of Labor, 1960), in terms of secondary-level credit accumulation (Ross, 1983; Schreiber, 1964; Tesseneer \& Tesseneer, 1958; Thornburg, 1975), and have been retained in grade for at least one year (Jablonsky, 1970; Kaplan \& Luck, 1977; Lichter et al., 1962; Scales, 1969; Stroup \& Robins, 1972; U.S. Department of Labor, 1960).

7. Have a record of chronic poor attendance (Berlowitz \& Durand, 1976; Cervantes, 1965; Hicks, 1969; Kaplan \& Luck, 1977; Layton, 1953; Lichter et al., 1962; Ross, 1983, Stroup \& Robins, 1972). While attendance definitions vary, absences in excess of ten days per year are commonly reported. 
8. Have low participation in extra-curricular activities (Cervantes, 1965; Gragg, 1949; Livingston, 1958; Scales, 1969; Snepp, 1953).

9. Have school-related behavioral and discipline problems (Beck \& Muia, 1981; Cervantes, 1965; Hicks, 1969; Kaplan \& Luck, 1977; Scales, 1969; Snepp, 1953) which contribute to a high rate of suspension and/or expulsion (Berlowitz \& Durand, 1976; Children's Defense Fund, 1960).

10. If low-achieving and/or educationally disadvantaged be eligible to receive basic skills remediation during elementary school (Berlowitz \& Durand, 1976; Carter, 1984; Mertens, 1972), or be eligible for participation in special education programs (Mahan \& Johnson, 1983) and alternative schools (Arnove \& Strout, 1980; Raywid, 1984).

11. Give the following common reasons for dropout: feelings of non-belonging and/or lack of status in the school organization, and an absence of help and encouragement to remain in school (Mahan \& Johnson, 1983; Oregon Department of Education, 1981; Snepp, 1953; Thornburg, 1975; U.S. Department of Labor, 1960).

Demographic description of the population is provided in Propositions 1, 2, 3. Propositions 4-6 include personal-social, and academic deficit characteristics. Propositions 7-8 include social/behavioral symptons correlated with student perceptions of reasons for dropout. While demographic data, personal-social characteristics, and behavioral symptoms are correlates of potential dropout and provide a broad description of a generalized student 
population, these descriptors are not equally helpful in determining an educational response to student needs. Focus on Propositions 6, 9, 10, 11, 12 support an emphasis on those student attitudes and behaviors which an educational system can reasonably impact -- educational performance and achievement; motivation, locus of control, and self-esteem as it is affected by the educational experience.

In this study, educational histories, as well as student perceptions of their experiences will be examined to identify high-risk factors which schools can respond to and/or influence.

\section{Description of the Sample Population}

What grade levels are represented in the alternative programs?

\section{What is the ratio of male and female students?}

Table I displays grade level, male/female, and total student enrollment/in the five study sample programs coded A-E. The size of the study body served in each program varies and so does its high-school grade level (9-12) representation.

Program A served 47 students, B served 385, C served 211, D 83 and E 31. Programs A, B, C are separate and unique alternative programs. D and E are schools-within-a-school. While Programs A, D, and E more often receive students through informal referral/transfer from regular high schools, $B$ and $C$ usually limit enrollment to students who have formally dropped out of a regular high school program. 
TABLE I

Male/Female and Grade by Alternative Program

\begin{tabular}{|c|c|c|c|c|c|c|c|}
\hline \multirow[b]{2}{*}{$\begin{array}{c}\text { Alternative } \\
\text { Program }\end{array}$} & \multirow[b]{2}{*}{ Sex } & & \multicolumn{5}{|c|}{ GRAUE LEVELS } \\
\hline & & & 9 & 10 & 11 & 12 & Total \\
\hline 1 & $\begin{array}{l}\text { Male } \\
\text { Female } \\
\text { Total }\end{array}$ & $\mathrm{N}$ & $\begin{array}{c}8 \\
(17 \%) \\
4 \\
(98) \\
12 \\
(26 \%)\end{array}$ & $\begin{array}{c}4 \\
(9 \%) \\
6 \\
(13 \%) \\
10 \\
(218)\end{array}$ & $\begin{array}{c}5 \\
(118) \\
9 \\
(198) \\
14 \\
(30 \%)\end{array}$ & $\begin{array}{c}8 \\
(17 \%) \\
3 \\
(68) \\
11 \\
(238)\end{array}$ & $\begin{array}{c}25 \\
(53 \%) \\
22 \\
(47 \%) \\
47 \\
(100 \%)\end{array}$ \\
\hline 1 & $\begin{array}{l}\text { Male } \\
\text { Female } \\
\text { Total }\end{array}$ & $\mathbf{N}$ & $\begin{array}{c}2 \\
(1 \%) \\
2 \\
(1 \%) \\
4 \\
(1 \%)\end{array}$ & $\begin{array}{c}35 \\
(98) \\
31 \\
(8 \%) \\
66 \\
(178)\end{array}$ & $\begin{array}{c}72 \\
(198) \\
60 \\
(16 \%) \\
132 \\
(348)\end{array}$ & $\begin{array}{c}104 \\
(27 \%) \\
79 \\
(21 \%) \\
183 \\
(48 \%)\end{array}$ & $\begin{array}{c}213 \\
(55 \%) \\
172 \\
(458) \\
385 \\
(100 \%)\end{array}$ \\
\hline 1 & $\begin{array}{l}\text { Male } \\
\text { Female } \\
\text { Total }\end{array}$ & $\mathrm{N}$ & $\begin{array}{c}18 \\
(98) \\
11 \\
(58) \\
29 \\
(148)\end{array}$ & $\begin{array}{c}27 \\
(138) \\
24 \\
(118) \\
51 \\
(248)\end{array}$ & $\begin{array}{c}28 \\
(138) \\
27 \\
(138) \\
55 \\
(26 \%)\end{array}$ & $\begin{array}{c}43 \\
(20 \%) \\
33 \\
(16 \%) \\
76 \\
(36 \%)\end{array}$ & $\begin{array}{c}116 \\
(55 \%) \\
95 \\
(45 \%) \\
211 \\
(100 \%)\end{array}$ \\
\hline D & $\begin{array}{l}\text { Male } \\
\text { Female } \\
\text { Total }\end{array}$ & $\mathrm{N}$ & $\begin{array}{c}23 \\
(28 \%) \\
18 \\
(228) \\
41 \\
(50 \%)\end{array}$ & $\begin{array}{c}15 \\
(188) \\
10 \\
(128) \\
25 \\
(308)\end{array}$ & $\begin{array}{c}3 \\
(4 \%) \\
7 \\
(8 \%) \\
10 \\
(12 \%)\end{array}$ & $\begin{array}{c}3 \\
(4 \%) \\
4 \\
(5 \%) \\
7 \\
(8 \%)\end{array}$ & $\begin{array}{c}44 \\
(53 \%) \\
39 \\
(47 \%) \\
83 \\
(400 \%)\end{array}$ \\
\hline $\mathrm{E}$ & $\begin{array}{l}\text { Male } \\
\text { Female } \\
\text { Total }\end{array}$ & $\mathrm{N}$ & $\begin{array}{c}4 \\
(13 \%) \\
6 \\
(198) \\
10 \\
(328)\end{array}$ & $\begin{array}{c}5 \\
(16 \%) \\
9 \\
(29 \%) \\
14 \\
(458)\end{array}$ & $\begin{array}{c}1 \\
(3 \%) \\
4 \\
(13 \%) \\
5 \\
(16 \%)\end{array}$ & $\begin{array}{c}1 \\
(3 \%) \\
1 \\
(3 \%) \\
2 \\
(7 \%)\end{array}$ & $\begin{array}{c}11 \\
(36 \%) \\
20 \\
(65 \%) \\
31 \\
(100 \%)\end{array}$ \\
\hline Male Tot & tal & $\mathrm{N}$ & $\begin{array}{c}55 \\
(7 \%)\end{array}$ & $\begin{array}{c}86 \\
(11 \%)\end{array}$ & $\begin{array}{c}109 \\
(148)\end{array}$ & $\begin{array}{c}159 \\
(218)\end{array}$ & $\begin{array}{c}409 \\
(54 \%)\end{array}$ \\
\hline Female T & Total & & $\begin{array}{c}41 \\
(58)\end{array}$ & $\begin{array}{c}80 \\
(11 \%)\end{array}$ & $\begin{array}{l}107 \\
(148)\end{array}$ & $\begin{array}{l}120 \\
(168)\end{array}$ & $\begin{array}{c}348 \\
(46 \%)\end{array}$ \\
\hline Program & Total & & $\begin{array}{c}96 \\
(138)\end{array}$ & $\begin{array}{c}166 \\
(228)\end{array}$ & $\begin{array}{c}216 \\
(298)\end{array}$ & $\begin{array}{c}279 \\
(378)\end{array}$ & $\begin{array}{c}757 \\
(100 \%)\end{array}$ \\
\hline
\end{tabular}


Program A has the most balanced grade-level population; 218 to $30 \%$ of its students are enrolied at each levei. Programs $B$ and $C$ (which limit their enrollment to high school dropouts) serve more students at grades eleven and twelve. Forty-eight percent of Program B students are twelfth graders, 348 eleventh graders, $17 \%$ are in grade ten and 18 in grade nine. In Program C, $36 \%$ of the students are in grade twelve, $26 \%$ in grade eleven, 248 in grade ten, and 148 in grade nine. Programs A, B, C (separate and unique alternative models) each serve more students at grades eleven and twelve than at nine and ten.

Approximately $80 \%$ of the students enrolled in Programs D and E (schools-within-a-school) are in the ninth and tenth grades. Program D has a greater percentage (50\%) and larger number (41) of ninth grade students than any other sample program. Program E has the largest percentage of tenth graders (45\%). Twelve percent of the students in D and $16 \%$ of the students in E are eleventh graders; $8 \%$ of D and $7 \%$ of E are in grade twelve.

Overall, $65 \%$ of the study sample students are in grades eleven and twelve, and $35 \%$ are in grades nine and ten. Students enrolled in the study sample alternatives are somewhat older than the potential dropout population described in the literature as in grade ten or at the transition from eighth to ninth grade.

Fifty-four percent of the alternative population is male, $46 \%$ is female. The gender ratio is fairly consistent across all grade levels and programs with the exception of Program E which has nearly twice as many females as males. These figures are similar to gender characteristics presented in the literature which indicate that while 
more males than females drop out, there are not large differences in the numbers.

What proportion of the alternative population is ethnic minority?

Students in the study sample program were identified according to five race/ethnic categories--American Indian, White, Black, Oriental, Hispanic. Each category except White is an ethnic minority in the school district. Table II presents the race/ethnic categories represented in each sample program.

TABLE II

Race/Ethnic Category by Alternative Program

\begin{tabular}{|c|c|c|c|c|c|c|c|}
\hline \multirow[b]{2}{*}{ CATEGORY } & & \multicolumn{5}{|c|}{ ALTERNATIVE PROGRAMS } & \multirow[b]{2}{*}{$\begin{array}{l}\text { Total Ethnic } \\
\text { Participation }\end{array}$} \\
\hline & & $\bar{A}$ & $\overline{\mathrm{B}}$ & $\mathrm{C}$ & $\bar{D}$ & $\bar{E}$ & \\
\hline American Indian & $\mathbf{N}$ & - & $\begin{array}{c}11 \\
(3 \%)\end{array}$ & $\begin{array}{c}6 \\
(3 \%)\end{array}$ & $\begin{array}{c}3 \\
(4 \%)\end{array}$ & $\begin{array}{c}5 \\
(16 \%)\end{array}$ & $\begin{array}{c}25 \\
(3 \%)\end{array}$ \\
\hline White & $\mathbf{N}$ & $\begin{array}{c}47 \\
(100 \%)\end{array}$ & $\begin{array}{c}336 \\
(878)\end{array}$ & $\begin{array}{c}136 \\
(65 \%)\end{array}$ & $\begin{array}{c}68 \\
(828)\end{array}$ & $\begin{array}{c}22 \\
(718)\end{array}$ & $\begin{array}{c}609 \\
(80 \%)\end{array}$ \\
\hline Black & $\mathbf{N}$ & - & $\begin{array}{c}27 \\
(7 q)\end{array}$ & $\begin{array}{c}54 \\
(26 \%)\end{array}$ & $\begin{array}{c}9 \\
(118)\end{array}$ & $\left(\begin{array}{c}3 \\
(10 \%)\end{array}\right.$ & $\begin{array}{c}93 \\
(12 \%)\end{array}$ \\
\hline Oriental & $\mathbf{N}$ & - & $\left(\begin{array}{c}1 \\
(38\end{array}\right)$ & $\begin{array}{c}9 \\
(4 \xi)\end{array}$ & - & - & $\begin{array}{l}10 \\
(18)\end{array}$ \\
\hline Hispanic & $\mathbf{N}$ & - & $\begin{array}{c}10 \\
(3 \%)\end{array}$ & $\begin{array}{c}6 \\
(3 \%)\end{array}$ & $\begin{array}{c}3 \\
(4 \%)\end{array}$ & $\begin{array}{c}1 \\
(3 \%)\end{array}$ & $\begin{array}{c}20 \\
(3 \%)\end{array}$ \\
\hline
\end{tabular}


Nineteen percent of the total alternative population was identified as ethnic minority; $12 \%$ Black, $3 \%$ American Indian, 3\% Hispanic, and 18 Oriental. Program B and $C$ included representatives of each ethnic category. Program A had no ethnic minorities and Program D and $\mathrm{E}$ had no Oriental students enrolled. The largest percentage of Black students (26\%) was served in Program C and Program E had the largest American Indian (168) representation.

What proportion of the alternative population are identified as low socio-economic status?

To describe student socio-economic status, participants in Free and Reduced Lumch were counted. Data were not available for 211 students (28\% of the total sample) in Program $C$ which is conducted during evening hours. Table III displays the Free and Reduced Lunch participants by alternative program.

TABLE III

Free/Reduced Lunch Participation by Alternative Program

\begin{tabular}{ccccccc}
\hline $\begin{array}{c}\text { Alternative } \\
\text { Program }\end{array}$ & Free & $\begin{array}{l}\text { Reduced } \\
\text { Lunch }\end{array}$ & $\begin{array}{l}\text { Sum of } \\
\text { Free/ } \\
\text { Reduced }\end{array}$ & $\begin{array}{l}\text { Non- } \\
\text { Participants }\end{array}$ & Total \\
\hline A & N & 21 & 3 & 24 & 23 & 47 \\
B & N & 105 & 12 & 117 & 268 & 385 \\
D & N & 15 & 4 & 19 & 64 & 83 \\
E & N & 9 & 1 & 10 & 21 & 31 \\
Total & N & 150 & 20 & 170 & 376 & 546 \\
& $(27 \%)$ & $(4 \%)$ & $(31 \%)$ & $(69 \%)$ & \\
\hline
\end{tabular}


Overall, $31 \%$ of the students for whom there were data were identified for low socio-economic status according to participation in the Free and Reduced Lunch program. Twenty-four students in Program A, 117 in Program B, 19 in Program D, and 10 in E were identified.

How long has the alternative population been enrolled in the district?

\section{What is the population's transfer/mobility history?}

Student transfer/mobility has been examined in four ways: (a) Longevity within the district, (b) frequencies of school changes during district enrollment, (c) duration of alternative enrollment during 1983-84, and (d) enrollment status of the study sample at the end of the 1983-84 school year.

Table IV presents district entry categories for all of the study sample population except seven students for whom data on grade-level entry were not available.

TABLE IV

Alternative Students' Entry Category by 1983-84 Grade Leve1

\begin{tabular}{|c|c|c|c|c|c|c|}
\hline \multirow{2}{*}{ Entry Category } & & \multicolumn{4}{|c|}{ GRADE LEVEL } & \multirow[b]{2}{*}{ Total } \\
\hline & & 9 & 10 & 11 & 12 & \\
\hline $\begin{array}{l}\text { Primary } \\
(\mathrm{K}-2)\end{array}$ & $\mathbf{N}$ & $\begin{array}{c}54 \\
(708)\end{array}$ & $\begin{array}{c}91 \\
(128)\end{array}$ & $\begin{array}{c}117 \\
(168)\end{array}$ & $\begin{array}{c}94 \\
(13 \%)\end{array}$ & $\begin{array}{c}356 \\
(48 \%)\end{array}$ \\
\hline $\begin{array}{l}\text { Elementary } \\
(3-5)\end{array}$ & $\mathrm{N}$ & $\left(\begin{array}{c}13 \\
(29)\end{array}\right.$ & $\begin{array}{c}17 \\
(20 \%)\end{array}$ & $\begin{array}{c}28 \\
(40 \%)\end{array}$ & $\begin{array}{c}59 \\
(8 \%)\end{array}$ & $\begin{array}{c}117 \\
(168)\end{array}$ \\
\hline $\begin{array}{l}\text { Middle School } \\
(6-8)\end{array}$ & $\mathbf{N}$ & $\begin{array}{c}15 \\
(28)\end{array}$ & $\begin{array}{c}20 \\
(38)\end{array}$ & $\begin{array}{c}18 \\
(28)\end{array}$ & $\begin{array}{c}33 \\
(48)\end{array}$ & $\begin{array}{c}86 \\
(11 \%)\end{array}$ \\
\hline $\begin{array}{l}\text { High School } \\
(9-12)\end{array}$ & $\mathbf{N}$ & $\begin{array}{c}14 \\
(28)\end{array}$ & $\begin{array}{c}36 \\
(58)\end{array}$ & $\begin{array}{c}53 \\
(7 \%)\end{array}$ & $\begin{array}{c}88 \\
(128)\end{array}$ & $\begin{array}{c}191 \\
(25 \%)\end{array}$ \\
\hline \multirow[t]{2}{*}{ Total } & & 96 & 164 & 216 & 274 & 750 \\
\hline & & $(138)$ & $(22 q)$ & $(298)$ & $(37 \%)$ & $(100 \%)$ \\
\hline
\end{tabular}


Fifty-two percent of the sample population transferred into the district after grade two. In terms of separate entry categories, the largest number of students, 356 students ( 458 of the total) have been in the district since primary. For 264 of these students, enrollment has been continuous; 92 students entered during primary but left the district for varied periods. Twenty-five percent of the student sample enrolled during high school, $16 \%$ during their intermediate elementary years, and $11 \%$ during middle school.

Seven percent of the students who entered during primary are in grade nine, $12 \%$ in grade ten, $16 \%$ are eleventh graders, and $13 \%$ are in grade twelve. Students who entered the district during elementary and middle school are fairly evenly distributed across grades nine through twelve; chose who entered during middle school represent between $2-4 \%$ and elementary enrollees account for 2-8\% of the enrollment across the grades. The majority of high school enrollees (12\%) are in grade twelve, $7 \%$ are in grade eleven, $5 \%$ in ten and $2 \%$ in grade nine. The majority of eleventh and twelfth graders entered the district during either their primary or high school years.

Table V presents 1983-84 altemative program enrollment according to district entry categories. 
TABLE V

Entry Category by Alternative Program

\begin{tabular}{|c|c|c|c|c|c|c|c|}
\hline \multirow{2}{*}{ Entry Category } & & \multicolumn{5}{|c|}{ ALTERNATIVE PROGRAMS } & \multirow[b]{2}{*}{ Total } \\
\hline & & $\bar{A}$ & $\overline{\mathrm{B}}$ & $\mathrm{C}$ & $\overline{\mathrm{D}}$ & $\bar{E}$ & \\
\hline $\begin{array}{l}\text { Primary } \\
(\mathrm{K}-2)\end{array}$ & $\mathbf{N}$ & $\begin{array}{c}31 \\
(66 \%)\end{array}$ & $\begin{array}{c}154 \\
(40 \%)\end{array}$ & $\begin{array}{c}101 \\
(49 \%)\end{array}$ & $\begin{array}{c}50 \\
(60 \%)\end{array}$ & $\begin{array}{c}20 \\
(65 \%)\end{array}$ & 356 \\
\hline $\begin{array}{l}\text { Elementary } \\
(3-5)\end{array}$ & $\mathbf{N}$ & $\begin{array}{c}8 \\
(17 \%)\end{array}$ & $\begin{array}{c}72 \\
(19 \%)\end{array}$ & $\begin{array}{c}26 \\
(138)\end{array}$ & $\begin{array}{c}7 \\
(8 \%)\end{array}$ & $\begin{array}{c}4 \\
(13 \%)\end{array}$ & 117 \\
\hline $\begin{array}{l}\text { Middle School } \\
(6-8)\end{array}$ & $\mathbf{N}$ & $\begin{array}{c}5 \\
(11 \%)\end{array}$ & $\begin{array}{c}48 \\
(138)\end{array}$ & $\begin{array}{c}15 \\
(78)\end{array}$ & $\begin{array}{c}14 \\
(17 \%)\end{array}$ & $\begin{array}{c}4 \\
(13 \%)\end{array}$ & 86 \\
\hline $\begin{array}{l}\text { High School } \\
(9-12)\end{array}$ & $\mathbf{N}$ & $\begin{array}{c}3 \\
(68)\end{array}$ & $\begin{array}{c}109 \\
(288)\end{array}$ & $\begin{array}{c}64 \\
(318)\end{array}$ & $\begin{array}{c}12 \\
(15 \%)\end{array}$ & $\begin{array}{c}3 \\
(98)\end{array}$ & 191 \\
\hline Total & $\mathbf{N}$ & 47 & 383 & 206 & 83 & 31 & 750 \\
\hline
\end{tabular}

Sixty percent or more of the students enrolled in Programs A, D, and E, $40 \%$ of Program B, and $49 \%$ of Program C enrollees have been in the district since K-2. Programs $B$ and $C$ respectively serve $28 \%$ and $31 \hat{z}$ of all the students who enrolled during high school.

What is the rate of school transfer for students who have been in the district for various periods of longevity?

Table VI. displays frequencies of school transfer after district enrollment. Because the district is organized into elementary, middle, and high schools, students would be expected to attend at least three different schools if they had been enrolled for their entire school career. 
TABLE VI

Frequency of School Changes by Entry Category

\begin{tabular}{|c|c|c|c|c|c|c|c|c|c|c|c|c|c|c|c|}
\hline \multirow[b]{2}{*}{ Entry Category } & \multicolumn{14}{|c|}{ Number of in-District School Changes } & \multirow{2}{*}{$\begin{array}{c}\text { Average } \\
\text { number of } \\
\text { school changes: }\end{array}$} \\
\hline & $\mathbf{0}$ & 1 & 2 & 3 & 4 & 5 & 6 & 7 & 8 & 9 & 10 & 11 & 12 & 13 & \\
\hline Primary $(K-2)$ & - & 10 & 29 & 68 & 70 & 57 & 38 & 31 & 18 & 16 & 7 & 8 & - & 4 & 5 \\
\hline Elementary $(3-5)$ & - & 5 & 9 & 29 & 25 & 19 & 15 & 9 & 3 & 1 & - & 1 & 1 & - & 4 \\
\hline Middle School (6-8) & - & 9 & 19 & 25 & 18 & 10 & 4 & - & 1 & - & - & - & - & - & 3 \\
\hline High School (9-12) & 89 & 58 & 30 & 10 & 3 & 1 & - & - & - & - & - & - & - & - & 1 \\
\hline Total & $\begin{array}{c}89 \\
(128)\end{array}$ & $\begin{array}{c}82 \\
(11 \%)\end{array}$ & $\begin{array}{c}87 \\
(128)\end{array}$ & $\left(\begin{array}{l}132 \\
(188)\end{array}\right.$ & $\begin{array}{l}116 \\
\text { (158) }\end{array}$ & $\begin{array}{c}87 \\
(12 \xi)\end{array}$ & $\begin{array}{c}57 \\
(88)\end{array}$ & $\begin{array}{c}40 \\
(5 \$)\end{array}$ & (58) & $\begin{array}{c}17 \\
(28)\end{array}$ & (13) & $\begin{array}{c}9 \\
(19)\end{array}$ & $(.18)$ & $\left(\begin{array}{c}4 \\
(.58)\end{array}\right.$ & \\
\hline
\end{tabular}


Overall, 528 of the alternative students transferred three or fewer times during their district enrollment, $48 \%$ transferred three or more times. Primary enrollees averaged five in-district school changes; the elementary student average was four, the middle school average was three. Students enrolled since the primary and elementary grades have a wider range of transfer frequencies than students who entered during middle and high school.

What is the duration of $1983-84$ alternative program participation?

Table VII displays frequencies of enrollment duration in months for each of the five study sample programs.

Table VII

Duration Frequencies in Months by Alternative Program

\begin{tabular}{|c|c|c|c|c|c|c|c|c|c|c|c|}
\hline \multirow{2}{*}{\multicolumn{2}{|c|}{$\begin{array}{l}\text { Alternative } \\
\text { Program }\end{array}$}} & \multicolumn{9}{|c|}{ MONTHS ATTENDED } & \multirow[b]{2}{*}{ Total } \\
\hline & & 1 & 2 & 3 & 4 & 5 & 6 & 7 & 8 & $\overline{9}$ & \\
\hline A & $\mathbf{N}$ & 3 & 2 & -- & 1 & 5 & 5 & 2 & 2 & 27 & 47 \\
\hline B & $\mathrm{N}$ & 15 & 32 & 44 & 41 & 46 & 31 & 25 & 32 & 119 & 385 \\
\hline C & $\mathbf{N}$ & 34 & 40 & 39 & 26 & 17 & 12 & 11 & 6 & 26 & 211 \\
\hline D & $\mathbf{N}$ & 8 & 8 & 12 & 7 & 10 & 1 & 3 & 2 & 32 & 83 \\
\hline E & $\mathbf{N}$ & 3 & 2 & 1 & 2 & 4. & 3 & 4 & 0 & 12 & 31 \\
\hline \multirow[t]{2}{*}{ TOTAL } & $\mathbf{N}$ & 63 & 84 & 96 & 77 & 82 & 52 & 45 & 42 & 216 & 757 \\
\hline & & $(8 \%)$ & 18) & $3 \%)$ & $10 \%$ & 11\%) & $(78)$ & $(68)$ & $(58)$ & $(298)$ & $(100 \%)$ \\
\hline
\end{tabular}



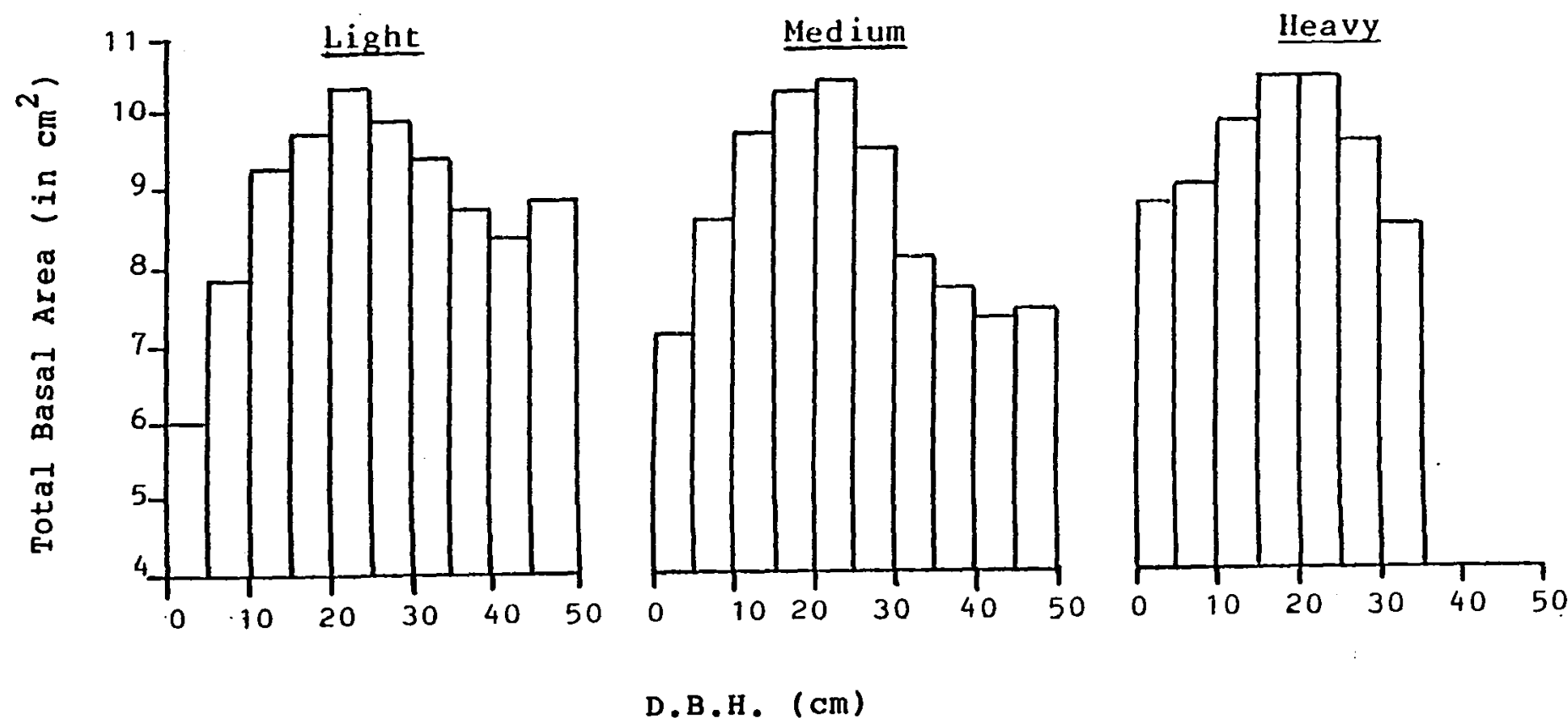

Figure 3. Natural log of the total basal area per one-half hectare represented by individuals at each increment of $5 \mathrm{~cm}$ in d.b.h. Log values allowed graphic representation on paper. 
TABLE XX

MEAN VALUES WITH STANDARD ERRORS FOR DENSITY WFTHIN PLOTS HAVING DIFFERENT LEVELS OF INFECTION

\begin{tabular}{|c|c|c|c|}
\hline Plot Size & Tree Size & $\begin{array}{c}\text { Infection } \\
\text { Level }\end{array}$ & No. of Plants \\
\hline One sq. Meter & $\begin{array}{l}\text { Seedlings } \\
(<6 \mathrm{~cm} \text { ht. })\end{array}$ & $\begin{array}{l}\text { Light } \\
\text { Medium } \\
\text { Heavy }\end{array}$ & $\begin{array}{l}0.44 \pm 0.13^{\mathrm{a}} \mathrm{ab} \\
0.68 \pm 0.14 \mathrm{~b}^{\mathrm{b}} \\
1.41 \pm 0.30^{-}\end{array}$ \\
\hline 25 Sq. Meters & $\begin{array}{l}\text { Saplings } \\
(>6 \mathrm{~cm} \text {, } \\
<2 \mathrm{mht})\end{array}$ & $\begin{array}{l}\text { Light } \\
\text { Medium } \\
\text { Heavy }\end{array}$ & $\begin{array}{l}0.54 \pm 0.15^{\mathrm{a}} \\
4.10 \pm 1.22^{\mathrm{b}} \\
9.32 \pm 1.11^{\mathrm{c}}\end{array}$ \\
\hline $50 \mathrm{sq}$. Meters & $\begin{array}{l}\text { Immature Trees } \\
\text { (> } 2 \mathrm{~m} \mathrm{ht.} \\
<16 \mathrm{~cm} \mathrm{d.b.h.}\end{array}$ & $\begin{array}{l}\text { Light } \\
\text { Medium } \\
\text { Heavy }\end{array}$ & $\begin{array}{l}1.70 \pm 0.25^{\mathrm{a}} \\
3.48 \pm 0.35^{\mathrm{b}} \\
4.29 \pm 0.42^{\mathrm{b}}\end{array}$ \\
\hline $100 \mathrm{sq}$. Meters & $\begin{array}{l}\text { Mature Trees } \\
(\mathrm{d.b.h.}> \\
14.5 \mathrm{~cm})\end{array}$ & $\begin{array}{l}\text { Light } \\
\text { Medium } \\
\text { Heavy }\end{array}$ & $\begin{array}{l}4.02 \pm 0.34^{a} \\
4.72 \pm 0.37^{a} \\
4.73 \pm 0.25^{a}\end{array}$ \\
\hline
\end{tabular}

$1_{\text {Within a column pertaining to a particular plot }}$ size, any pair of mean values that do not have at least one common leter are significantly different, $(p<0.05)$.

${ }^{2}$ sample sizes for lightly, moderately, and heavily infected plots were 50, 50, and 100 respectively. 


\section{TABLE XXI}

\section{MEAN VALUES WITH STANDARD ERRORS FOR D.B.H. OF MATURE TREES IN PLOTS WITH PIFFERENT LEVELS OF INFECTION}

Mean D.B.H. ( cm)

$$
\begin{aligned}
& \text { Light }(n=201) \\
& \text { Medium }(n=236) \\
& \text { Heavy }(n=473)
\end{aligned}
$$$$
22.90 \pm 0.51^{a}
$$$$
20.23+0.31^{b}
$$$$
20.05 \pm 0.22^{b}
$$

${ }^{1}$ Any pair of mean values that do not have the same letter in common are significantly different, $(p<0.05)$. 
heavily infected stands was determined by two-way ANOVA to be significantly less than opposite lightly infected stands (Figures 4 and 5 ).

\section{DISCUSSION}

Mortality occurs during each stage in the population life cycle, thereby reducing the number of individuals in a cohort. Stand density would mirror the effects of infection on seed production (reduction in size) if there was no effect (increase) in age specific survival. My review has shown that survival rates vary between lightly and heavily infected stands.

Dwarf mistletoe reduces the number of seeds produced by its lodgepole host. As a result, the mean number of seeds produced per square meter of forest floor was reduced in heavily infected plots, and the mean number of seeds that reached the floor and germinated declined with the level of infection.

Survival of one year old seedlings was significantly higher in heavily infected plots than in lightly infected plots. This increased survival negates the effects of lower germling density (and seed production) in these same plots, as indicated by the consistent (but insignificant) increase in one year old seedling density with the level of infection. The number of safe-sites which are suitable for survival after germination apparently limits seedling 


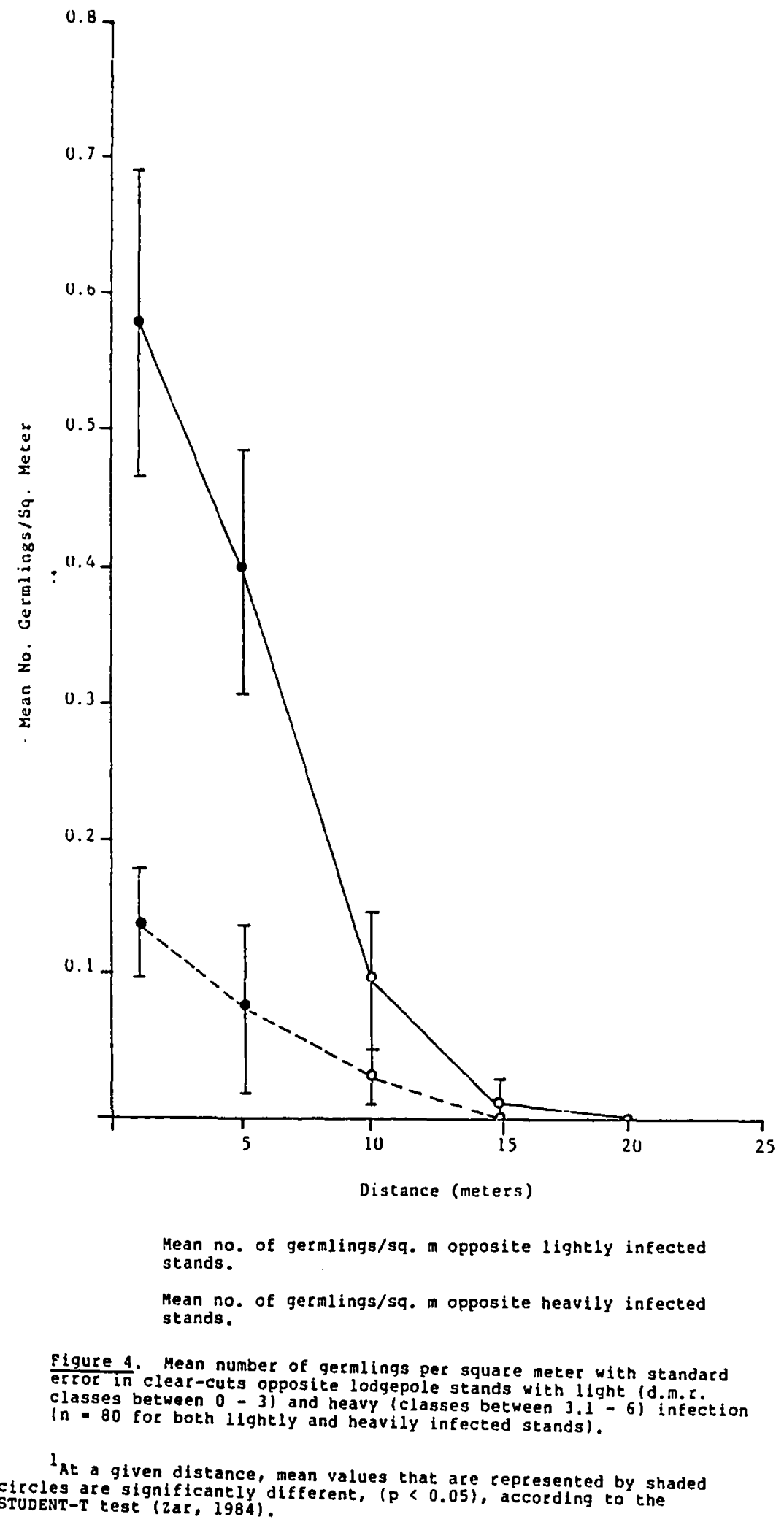


TABLE XII

Achievement on Reading, Math, and Language Tests

\begin{tabular}{|c|c|c|c|c|c|c|c|}
\hline \multirow{2}{*}{\multicolumn{2}{|c|}{$\begin{array}{l}\text { Alternative } \\
\text { Program }\end{array}$}} & \multicolumn{2}{|c|}{ Reading } & \multicolumn{2}{|c|}{ Math } & \multicolumn{2}{|c|}{ Language } \\
\hline & & \multicolumn{2}{|c|}{ Pass No Pass } & \multicolumn{2}{|c|}{ Pass No Pass } & \multicolumn{2}{|c|}{ Pass No Pass } \\
\hline A & $\mathbf{N}$ & $\begin{array}{c}35 \\
(75 \%)\end{array}$ & $\begin{array}{c}12 \\
(258)\end{array}$ & $\begin{array}{c}32 \\
(688)\end{array}$ & $\begin{array}{c}15 \\
(328)\end{array}$ & $\begin{array}{c}39 \\
(858)\end{array}$ & $\left(\begin{array}{c}7 \\
(15 \%\end{array}\right)$ \\
\hline B & $\mathrm{N}$ & $\begin{array}{c}228 \\
(778)\end{array}$ & $\begin{array}{c}69 \\
(23 \%)\end{array}$ & $\begin{array}{c}165 \\
(568)\end{array}$ & $\begin{array}{c}128 \\
(44 \delta)\end{array}$ & $\begin{array}{c}230 \\
(818)\end{array}$ & $\begin{array}{c}53 \\
(19 \%)\end{array}$ \\
\hline C & $\mathrm{N}$ & $\begin{array}{c}127 \\
(76 \%)\end{array}$ & $\begin{array}{c}41 \\
(248)\end{array}$ & $\begin{array}{l}103 \\
(618)\end{array}$ & $\begin{array}{c}65 \\
(39 \%)\end{array}$ & $\begin{array}{c}137 \\
(85 \%)\end{array}$ & $\begin{array}{c}25 \\
(15 \%)\end{array}$ \\
\hline D & $\mathbf{N}$ & $\begin{array}{c}50 \\
(68 \%)\end{array}$ & $\begin{array}{c}24 \\
(328)\end{array}$ & $\begin{array}{c}39 \\
(548)\end{array}$ & $\begin{array}{c}33 \\
(468)\end{array}$ & $\begin{array}{c}55 \\
(778)\end{array}$ & $\begin{array}{c}16 \\
(23 \%)\end{array}$ \\
\hline $\mathrm{E}$ & $\mathrm{N}$ & $\begin{array}{c}24 \\
(80 \%)\end{array}$ & $\begin{array}{c}6 \\
(20 \%)\end{array}$ & $\begin{array}{c}13 \\
(438)\end{array}$ & $\begin{array}{c}17 \\
(57 \%)\end{array}$ & $\begin{array}{c}21 \\
(75 \%)\end{array}$ & $\begin{array}{c}7 \\
(25 \%\end{array}$ \\
\hline $\begin{array}{l}\text { Students } \\
\text { Tested }\end{array}$ & $\mathrm{N}$ & $\begin{array}{c}464 \\
(75 \%)\end{array}$ & $\begin{array}{c}152 \\
(25 \%)\end{array}$ & $\begin{array}{c}352 \\
(58 \%)\end{array}$ & $\begin{array}{c}258 \\
(428)\end{array}$ & $\begin{array}{c}482 \\
(82 q)\end{array}$ & $\begin{array}{c}108 \\
(18 \%)\end{array}$ \\
\hline \multirow{2}{*}{$\begin{array}{l}\text { Students } \\
\text { Missing } \\
\text { Data }\end{array}$} & & & & & & & \\
\hline & $\mathrm{N}$ & & 141 & & 147 & & 167 \\
\hline Total & $\mathbf{N}$ & & 757 & & 757 & & 757 \\
\hline
\end{tabular}


Overall, $82 \%$ of the tested students passed language usage, 78\% passed reading and $58 \%$ passed the math tests. A similar proporition of passing students within subject areas holds for all programs except one. In Program E a larger percentage of students passed reading ( $80 \%$ ) instead of language (75\%), and Program $E$ had the lowest percentage of students passing the PALT in math (43\%).

What proportion of the population has experienced suspension during enrollment in the district?

Table XIII displays numbers of students in each alternative program who have a record of at least one suspension.

TABLE XIII

Students with Suspension History by Alternative Program

\begin{tabular}{lccc}
\hline $\begin{array}{l}\text { Program/ } \\
\text { Enroliment }\end{array}$ & & \multicolumn{1}{c}{$\begin{array}{c}\text { Number of Students } \\
\text { Who Have Been Suspended }\end{array}$} \\
\hline A & 47 & N & 15 \\
& & & $(32 \%)$ \\
B & 385 & N & 201 \\
& & & $(52 \%)$ \\
C & 211 & N & 79 \\
& & & $(37 \%)$ \\
D & 83 & N & 45 \\
& & & $(548)$ \\
E & 31 & N & 8 \\
& & & $(26 \%)$ \\
\hline Total: & 757 & & 348 \\
& & & $(46 \%)$ \\
\hline
\end{tabular}


Forty-six percent of the alternative student sample have been suspended at least once during their district careers. Program B (a separate and unique school and the largest alternative program) and Program D (the largest school-within-a-school program) have the highest percentage of students with suspension history. The smallest alternative (Program E) has the lowest percentage of students with suspension records.

Table XIV presents reason codes for 370 instances of the students' suspensions. 
TABLE XIV

Erequency of Suspension by offense Code

\begin{tabular}{|c|c|c|c|}
\hline Suspension Categories & Definition & Frequency & $\begin{array}{l}\text { Category } \\
\text { Totals }\end{array}$ \\
\hline School Attendance & $\begin{array}{l}\text { Truancy } \\
\text { Cutting class } \\
\text { Leaving campus w/o } \\
\text { permission } \\
\text { Leaving class w/o } \\
\text { permission } \\
\text { Tardiness } \\
\text { Forged signature } \\
\text { Other }\end{array}$ & $\begin{array}{r}37 \\
4 \\
4 \\
\\
2 \\
1 \\
1 \\
25\end{array}$ & 74 \\
\hline $\begin{array}{l}\text { Behavior with } \\
\text { Other Students }\end{array}$ & $\begin{array}{l}\text { Fighting } \\
\text { Assault } \\
\text { Threatening } \\
\text { Profanity } \\
\text { Other }\end{array}$ & $\begin{array}{r}45 \\
18 \\
4 \\
1 \\
3\end{array}$ & 71 \\
\hline Behavior with Staff & $\begin{array}{l}\text { Insubordination } \\
\text { Abusive language } \\
\text { Fighting } \\
\text { Assault } \\
\text { Threatening } \\
\text { Disrespect } \\
\text { Disruption of class } \\
\text { Other }\end{array}$ & $\begin{array}{r}43 \\
16 \\
6 \\
6 \\
5 \\
2 \\
2 \\
3\end{array}$ & 83 \\
\hline $\begin{array}{l}\text { Unacceptable } \\
\text { Individual Behavior }\end{array}$ & $\begin{array}{l}\text { Drugs } \\
\text { Cigarettes, smoking } \\
\text { Disruptive behavior } \\
\text { Alcohol } \\
\text { Loss of self-control } \\
\text { In off-limits area } \\
\text { Profanity } \\
\text { Other }\end{array}$ & $\begin{array}{r}44 \\
28 \\
9 \\
6 \\
5 \\
2 \\
1 \\
8\end{array}$ & 103 \\
\hline Criminal Behavior & $\begin{array}{l}\text { Theft } \\
\text { Firecrackers } \\
\text { Vandalism } \\
\text { Arson } \\
\text { Trespassing } \\
\text { Extortion } \\
\text { Other }\end{array}$ & $\begin{array}{r}12 \\
7 \\
3 \\
2 \\
1 \\
1 \\
6\end{array}$ & 32 \\
\hline General & Multiple offenses & 7 & 7 \\
\hline Total Number of Suspe & & & 370 \\
\hline
\end{tabular}


Sixty-one percent of the coded suspensions $(\mathrm{N}=228)$ are for specific school-related behaviors regarding Attendance, Behavior with Other Students or Behavior with Staff. Fighting, Insubordination and Truancy account for $55 \%$ of all coded suspensions within the school-related categories. When the school-related categories are ranked, Behavior with Staff is first ( 83 suspensions), Attendance is second (74 suspensions), and Behavior with Other Students is third (71 suspensions).

What proportion of the population has a history of participation in supplementary or other alternative programs?

Records for the student sample were examined to determine how many were identified for participation in supplementary and/or other alternative programs prior to their 1983-84 alternative program placement. The data are nominal and represent neither the number of times nor the duration of supplementary or alternative identification and participation. Table XV presents the number of students in each program with and without any district history of supplementary program participation. 
TABLE XV

Number of Students with/without Identification for District Supplementary Programs

\begin{tabular}{lcccc}
\hline $\begin{array}{c}\text { Alternative } \\
\text { Program }\end{array}$ & $\begin{array}{c}\text { Students with History } \\
\text { of Participation in } \\
\text { Supplements }\end{array}$ & $\begin{array}{c}\text { Students With No } \\
\text { Supplementary } \\
\text { Participation }\end{array}$ & Total \\
\hline A & N & 22 & 25 & 47 \\
B & N & $187 \%)$ & $(53 \%)$ & $(100 \%)$ \\
C & N & 117 & 201 & 385 \\
& & $(55 \%)$ & $(52 \%)$ & $(100 \%$ \\
D & N & 52 & 94 & 211 \\
& & $(63 \%)$ & $(45 \%)$ & $(100 \%)$ \\
E & N & 20 & 31 & 83 \\
& & $(65 \%)$ & $(37 \%)$ & $(100 \%)$ \\
& N & 395 & 11 & 31 \\
Total & $(52 \%)$ & $(35 \%)$ & $(100 \%$ \\
& & & $(48 \%)$ & $(100 \%)$ \\
\hline
\end{tabular}

Fifty-two percent of the student sample have been identified for one or more supplementary or alternative programs during their district enrollment and prior to the 1983-84 school year. Forty-eight percent of the student sample have no record of supplementary program participation.

Table XVI. displays the frequencies of student identification for Special Education, Chapter I and other alternative programs. The N's are not exclusive to the named categories; students who participated in Special Education, Chapter I and another alternative program are included three times--once for each category. 
TABLE XVI

Frequencies of Identification for Special Education, Chapter $I$, and other Alternatives by Program

\begin{tabular}{|c|c|c|c|c|c|}
\hline Program & & $\begin{array}{c}\text { Special } \\
\text { Education }\end{array}$ & Chapter I & Alternatives & $\begin{array}{c}\text { Total 1983-84 } \\
\text { Enrollment }\end{array}$ \\
\hline A & $\mathrm{N}$ & 15 & 13 & 5 & 47 \\
\hline B & $\mathrm{N}$ & 124 & 91 & 39 & 385 \\
\hline $\mathrm{C}$ & $\mathrm{N}$ & 74 & 68 & 18 & 211 \\
\hline $\mathrm{D}$ & $\mathbf{N}$ & 36 & 21 & 11 & 83 \\
\hline$E$ & $\mathbf{N}$ & 7 & 17 & 4 & 31 \\
\hline Total & $\mathrm{N}$ & $\begin{array}{c}256 \\
(34 \%)\end{array}$ & $\begin{array}{c}210 \\
(28 \%)\end{array}$ & $\begin{array}{c}77 \\
(108)\end{array}$ & 757 \\
\hline
\end{tabular}

Of the total alternative school study sample, 256 (34\%) were identified for Special Education services at least once during their enrollment in the district; 210 (28\%) were identified for Chapter I services; 77 (10\%) participated in another alternative program within the district prior to enrollment in the 1983-84 alternative program.

Table XVII. displays frequencies of student participation in Special Education, Chapter I, other alternative programs and combinations of the supplements/alternatives. The N's are unduplicated. 
TABLE XVII

\section{Frequencies of Supplementary Program Participation}

\begin{tabular}{|c|c|c|c|c|c|c|c|c|c|c|}
\hline \multicolumn{2}{|c|}{ Program } & \multirow{2}{*}{$\begin{array}{c}\begin{array}{c}\text { Special } \\
\text { Ed. }\end{array} \\
\frac{6}{(13 \%)}\end{array}$} & \multirow{2}{*}{$\frac{\text { Chapter }}{I}$} & \multirow{2}{*}{$\begin{array}{c}\text { Other } \\
\text { Alternative }\end{array}$} & \multirow{2}{*}{$\begin{array}{c}\begin{array}{c}\text { Spec. Ed. } \\
\text { and } \\
\text { Chapter I }\end{array} \\
\frac{6}{(13 \%)}\end{array}$} & \multirow{2}{*}{$\begin{array}{l}\text { Spec. Ed. } \\
\text { and Other } \\
\text { Alternative }\end{array}$} & \multirow{2}{*}{$\begin{array}{l}\text { Chapter I } \\
\text { and Other } \\
\text { Alternative }\end{array}$} & \multirow{2}{*}{$\begin{array}{l}\text { Spec. Ed. } \\
\text { Chapter I } \\
\text { and Other } \\
\text { Alternative } \\
\qquad \begin{array}{c}1 \\
(2 \%)\end{array}\end{array}$} & \multirow{2}{*}{$\begin{array}{c}\text { None } \\
\begin{array}{c}25 \\
(53 \%)\end{array}\end{array}$} & \multirow{2}{*}{$\begin{array}{l}\text { Total } \\
\text { 1983-84 } \\
\text { Enrollment } \\
47\end{array}$} \\
\hline A & $\mathbf{N}$ & & & & & & & & & \\
\hline $\mathrm{B}$ & $\mathbf{N}$ & $\begin{array}{c}67 \\
(17 \%)\end{array}$ & $\begin{array}{c}40 \\
(11 \%)\end{array}$ & $\begin{array}{c}16 \\
(4 \%)\end{array}$ & $\begin{array}{c}38 \\
(10 \%)\end{array}$ & $\begin{array}{c}10 \\
(3:)\end{array}$ & $(1 \%)$ & $\begin{array}{c}9 \\
(2 q)\end{array}$ & $\begin{array}{c}201 \\
(52 \%)\end{array}$ & 385 \\
\hline C & $\mathbf{N}$ & $\begin{array}{c}39 \\
(19 \%)\end{array}$ & $\begin{array}{c}32 \\
(15 \%)\end{array}$ & $\begin{array}{c}7 \\
(3 q)\end{array}$ & $\begin{array}{c}28 \\
(13 q)\end{array}$ & $\begin{array}{c}3 \\
(1 \%)\end{array}$ & $\left(\begin{array}{c}4 \\
(2 \xi)\end{array}\right.$ & $\left(\begin{array}{c}4 \\
(2 \%\end{array}\right)$ & $\begin{array}{c}94 \\
(45 \xi)\end{array}$ & 211 \\
\hline $\mathrm{D}$ & $\mathbf{N}$ & $\begin{array}{c}23 \\
(28 \%)\end{array}$ & $\begin{array}{c}7 \\
(8 \%)\end{array}$ & $\begin{array}{c}7 \\
(8 \%)\end{array}$ & $\begin{array}{c}11 \\
(13 \%)\end{array}$ & $\left(\begin{array}{c}1 \\
18\end{array}\right)$ & $\left(\begin{array}{c}2 \\
(2 \xi)\end{array}\right.$ & $\left(\begin{array}{c}1 \\
1 \%\end{array}\right)$ & $\begin{array}{c}31 \\
(37 \xi)\end{array}$ & 83 \\
\hline$E$ & $\mathbf{N}$ & 0 & $\left(\begin{array}{c}11 \\
(35 \%)\end{array}\right.$ & $\left(\begin{array}{c}1 \\
3:\end{array}\right)$ & $\left(\begin{array}{c}5 \\
(16 \%)\end{array}\right.$ & $\begin{array}{c}2 \\
\left(7 \frac{\circ}{6}\right)\end{array}$ & $\left(\begin{array}{c}1 \\
(3 q)\end{array}\right.$ & -- & $\begin{array}{c}11 \\
(36 \%)\end{array}$ & 31 \\
\hline Tota 1 & $N$ & $\begin{array}{c}155 \\
(18 \%)\end{array}$ & $\begin{array}{c}95 \\
(13 \%)\end{array}$ & $\begin{array}{c}32 \\
(4 !)\end{array}$ & $\begin{array}{c}88 \\
(12 \%)\end{array}$ & $\begin{array}{c}18 \\
(2 \%)\end{array}$ & $\begin{array}{c}12 \\
(2 \%)\end{array}$ & $\begin{array}{c}15 \\
(2 \%)\end{array}$ & $\begin{array}{c}362 \\
(48 \%)\end{array}$ & 757 \\
\hline
\end{tabular}


Student Perceptions of Educational Experiences

A total of 81 alternative students participated in an interview designed to gather information on student perceptions of their educational experiences in both the regular and alternative school programs. It is important to note that the two critical variables for interview were (1) entry to the district at K-2, and (2) active enrollment during the final quarter of the 1983-84 school year.

The representativeness of the interview sample was established by comparing it to the whole group in terms of both personal/social and school-related characteristics. A summary description is in Appendix D.

The interview questions were designed to elicit perceptions of students' academic and social experiences during their educational careers in both regular and alternative school programs. There were five categories of questions: (1) Personal identification; (2) Curricular/instructional organization in both regular and alternative programs; (3) Educational performance; (4) Perceptions of status in the school organization; and (5) Transition from the regular to the alternative high school program. A copy of the Interview Questionnaire is in Appendix C.

In order to support a detailed interpretation of the response data, each part of a student's answer to any given question was separately tallied and a frequency count of common response elements was maintained. When tables contain frequency counts in excess of the number of total respondents $(\mathrm{N}=81)$ the counts are in terms of responses. For example, Question 9 was stated as follows: 
What are the coursework requirements (of the alternative program)? How much work is required? How do you earn credit? Do you receive grades? What is the quality of work -difficult/easy?

One student's verbatim response was:

About the same requirements to graduate. It's a lttle different because you work at your own pace; you still work every day. Pass/no pass. The work is easier. Actually tests are harder. They make you work and keep after you. At (regular program) they just say "do your work." These people care about you and what you're going to be. All classes have tests; you have to pass $75 \%$ and they're usually pretty long . . You gotta be here and do your work. It's a little easier but more than others you do more things as a group than otherwise to help you understand things.

Elements of this response were tallied in terms of coursework requirements, pace of work, grading requirements, teacher behaviors, and instructional mode (grouping).

\section{Personal Identification}

The first section of the interview (Questions 1-7) was devoted to questions of self-identification in terms of grade level, previous schools attended, family and current living arrangements.

Twelve of the students interviewed were in grade nine; 21 were tenth graders; 30 were in grade eleven and 18 were in grade twelve. Twenty-one students had been enrolled at the alternative less than a year; 32 students had been enrolled from one to two years; 26 had been enrolled between two and three years; 2 students had been enrolled for four high school years.

Thirty-four interviewees (42\%) lived with both parents; 27 (33\%) lived with their mothers; 11 (14\%) lived with guardian(s) other than 
their parents; 9 (11\%) lived with one natural parent and a step-parent. Seventy students ( $86 \%$ ) lived with one or both parents, and $11(24 \%)$ resided with non-family members.

Curriculum and Organization

Questions 8-11 asked students to focus on perceptions of the curriculum and organization of regular and alternative programs. Students made comparisons between coursework and credit requirements, instructional support practices, and the role of the teacher. Table XVIII presents response categories and frequency counts. 
TABLE XVIII

Comparisons of Gurriculum and Organization Regular and Alternative Programs

\section{Program Difficulty}

The work is easier in the alternative

The work is of the same difficulty

\section{Program Requirements}

There is less work in the alternative

The amount of work is the same

There is more work in the alternative

\section{Instructional Support Practices}

We work at our own pace

We have class time to do our work, and therefore seldom have homework

We work in groups, cooperatively

\section{Credit/Grades}

We have Pass/No Pass

15

We get credit, not grades

We can get grades

\section{Program Schedule}

Shorter classes make it more interesting

They're the same classes, but different kinds of courses, allowing us some choice

\section{Teacher Role}

Teachers care about us, encourage, and give us advice; it's a family

Teachers explain and help us

Teachers explain, help, and there is less pressure 
Students reported that credit and/or grades were earned by attendance and completion of work. When the amount and difficuity of work between regular and alternative programs was compared, 24 responses indicated less work required in the alternatives; nine responses indicated more work, and eight responses indicated that the amount of work was the same. One student explained:

There is the same amount of work, but it's easier here because teachers sit down and explain it to you.

Seventy-nine responses described regular and alternative coursework as equally difficult. Fifty-five responses described alternative coursework as easier.

Coursework may have been more easily perceived as an independent topic when students recalled experiences within the regular program. In the alternative program, the coursework context includes teacher participation, as well as some element of choice (or possibly "control") over curriculum offerings. For example, 16 students noted that the aiternative curriculum was paced, and allowed students to work at their own rates; 22 students reported that their work could be finished during class time instead of requiring homework. Seventeen students pointed out that while the courses in the alternative were the same as regular in terms of content, there were more choices within subject areas, and different content approaches in the alternative.

Seven respondents spoke of alternative program teachers "not pressuring them" For example, one student said: 
It was stressful in both middle and high school. In high school there was a lot of work and teachers didn't fully explain it. To get all the work in that I didn't understand was hard. My mom couldn't help me because it had changed. The teachers just told me to pay more attention.

Sixteen students described the alternative teachers as "encouraging," "helping" (one to one, or by putting a student where he belonged to start), "explaining the work better," or as persons who "take the time" to communicate a desire to help students succeed.

Table XIX presents student perceptions of the main differences between regular and alternative programs. Students' responses fell in three categories: teachers, the schedule, and "other." All but five responses were positive for the alternative over the regular program. The more negative comments regarding alternatives indicated that regular program work was more demanding $(\mathrm{N}=2)$, that alternative sports and social opportunities were inadequate $(\mathrm{N}=1)$, that alternatives provided less discipline than the regular program $(\mathrm{N}=1)$, and that more "problem kids" attended alternatives $(\mathrm{N}=1)$. 
TABLE XIX

Differences Between Regular and Alternative Programs

Student Comments

Response Frequency

\section{Teachers}

Teachers help you

Teachers have time for you

16

Teachers help you individually

12

Teachers get to know you

12

Teachers show they care

10

Teachers take time to talk to you

10

Teachers are friendly

Teachers make sure you understand

6

Teachers are called by first names

6

Teachers don't treat you like a kid

Teachers give you time to finish

Schedule

Classes/courses are shorter

Classes are self-contained

Can do work during class time

There is less or no homework

11

1

1

1

Other

Fewer students

13

Can work at own pace

12

Stricter attendance rules

10

Teachers are called by their first names

8

It's like a family

Less pressure

Rewards, e.g., field trips

Smoking privileges

Can be yourself

Better food

Can work at a job

6

5

5

2

1

1

Total

184 
Comments about teachers were related to help with learning $(\mathrm{N}=40)$, to the quality of the personal teacher-student relationsinip $(N=39)$, or to the time teachers spent with students $(\mathrm{N}=27)$. Six students commented on the fanily quality of the alternative and five students said that "less pressure" is a key difference between regular and alternative programs. Seven comments noted the rewards and privileges available in the alternative for good work and/or behavior.

Eleven responses noted the shorter courses/classes in the alternative schedule. Thirteen students commented positively about the smaller student body and twelve students remarked positively about working at one's own pace.

Ten responses indicate a positive preference for "stricter" attendance rules in the alternative program. (Throughout the entire interview process, all responding students were well-versed in specifics of attendance rules and regulations and reasons for the rules.)

In the words of one student:

You can work at your own pace here. It seems like you're closer to everybody here. The teachers are different. You can talk to them. You've got a problem and they'11 understand it. At the regular school if I'm having a bad day my teacher would say, "What's wrong?" They try to work it out here. This school is like my family. They help me solve my problems.

\section{Educational Performance}

Question 15 asked students to describe themselves as learners and students. The interviewees responded with terms such as "Average," "Above Average," with both terms plus qualifications, or in terms of their effort. Table $\mathrm{XX}$ displays the responses. 
TABLE XX

Students: Perceptions of Seives as Learners/Students

Student Comments

Response Frequency

Average

Average with qualifications, e.g.

Not a good worker

But I like to learn; I try

But could do better

Until high school

Fast in some subjects; slow in others

A slow worker

But can't take pressre

Until middle school

Above Average

Above Average with qualifications, e.g.

Learn quickly

But teachers get to me

And love school

2

2

Below Average

Below Average with explanation, e.g.

Am just now getting serious

Don't like to work

Slow learner

Have disability

But I try hard

Work just to pass

If interested do better

There were 33 qualified descriptions. Twenty were worded in terms of perceived deficit descriptors; four related to student effort; three suggested that students performed as average learners only prior to 
high school; two students described themselves as "quick" and two reported that they loved school. Two others reported that since enrolling in the alternative program, they were getting serious about learning for the first time.

Table XXI displays student responses to Question 16: "How do you feel about school in general?" The majority of responses $(N=49)$ were interpreted as more "accepting" than positive. Responses were phrased in the context of the alternative experience.

TABLE XXI

How Alternative Students Feel About School in General

Student Comments

Response Frequency

More Accepting/Positive

It's all right; okay 33

I know education is important

I like it

9

I want to make something of myself; these teachers are helping me do that

Less Accepting/Negative

I don't like it

School is a waste of time; it is not useful

8

I am almost out

7

School is something you have to do

School is boring

I am tired of school

3

2

Total 
In general (but still positive) terms, one student said:

I like it and think it's important, the high school years especially. You really grow alot and then afterwards you go to college. You need those years to find out who and what you're going to be. These are the four most important and hardest years because things happen so fast.

In comparing his regular and alternative experience, another reported that:

School is good for everyone. It helps imderstanding things that are going on in the community and heips you deal with others, like on a job. Before the alternative, it was harder to deal with a lot of teachers, but after I got here it was all right. I could talk to them and they were willing to help me if I'm willing to learn. After I got here I cracked down hard and tried hard and my grades went up.

Only five students reported liking school. Thirty-three described school as being "all right." Twenty-seven students regarded school as an almost-completed task.

Questions 24 and 25 addressed issues of success in the regular and alternative programs. Table XXII presents student descriptions of their successes in their regular school program. 
TABLE XXII

Success in the Regular School Program

Student Comments

Response Frequency

Grades

25

- Teachers and my grades

16

Teachers; made me feel successful; kept me going

9

My attitude and grades

5

Sports

Getting along and knowing everyone

4

Getting work done successfully

4

Grades in special classes

3

Plays/drama

2

1

I never felt successful in the regular program

13

Total

82

Sixty-nine indicators of success in the regular program were given: 27 defined success in terms of grades; 9 in term of teachers, and 16 in terms of teachers plus grades. Five responses defined success through participation in sports or theater activities. Eight students perceived their successes in terms of somewhat more intrinsic terms--both personal attitude and grades were mentioned by five students, and three cited a successful completion of the required work as a measure of success.

Thirteen students reported never feeling success in the regular program. In one student's words: 
I never felt successful. I always felt dumber because I couldn't grasp things. I always needed someone to help me and explain it to me. in eignth grade language arts social studies I did real good. In social studies I got an $A$; at that time I felt that I had accomplished something in school.

Question 20 addressed perceptions of success in the alternative program. Student responses are presented in Table XXIII.

TABLE XXIII

Success in the Alternative School Program

Student Comments $\quad$ Response Frequency

Grades, credits

32

Teachers care for me; comment on my performance; tell me I'm doing well 17

Getting the work done $\quad 14$

Staying in school; attending 13

Passing classes $\quad 8$

My attitude and interest are improved;
I feel good about myself

I'm doing better

Rewards, e.g., field trips 3

I'm a teacher aide

Have made it thus far; have respect;

I'M doing it; feel comfortable here;

have learned a lot

1 each

I don't feel successful 4 
Thirty-two responses defined success in the alternative in terms of grades; 17 in terms of teachers; 5 in terms of rewards or privileges gained. Fifty-one reponses were in terms of improved student behavior or general feelings about school $(\mathrm{N}=7)$, feelings upon successful completion of work $(\mathrm{N}=14)$, feelings of being in control of personal school improvement $(\mathrm{N}=5)$, improved attendance $(\mathrm{N}=13)$, passing grades $(\mathrm{N}=8)$, and improvement in general $(\mathrm{N}=4)$.

One student explained:

I never fail at anything in here. I don't like to fail. (The alternative director) asks me to do different things, like next year she wants me to be a teacher aide. That makes me feel that I am successful.

Social Relations and School Status Perceptions

Questions 14 and 19-22 dealt with students' relationships with teachers, staff, administrators and peers during both regular and alternative experiences. Table XXIV presents students' descriptions of helping and social relationships with teachers and other staff during grade, middle and high school before their entry to the alternatives. 
TABLE XXIV

Relationships with School Staff

Student Comments

Response Frequency

Grade/Middle School Teachers

Helped; in or out of school; were tolerant

Explained things well

Talked, reached out to me, were like friends

Were patient

Prepared me for high school

Made the school work interesting

Left me alone

They didn't help me

High School Teachers

Put work in front of you and said "Do it" 8

Helped; explained things well

They gave me time to catch up on my work 4

They were on my side; were my friends 2

Instilled confidence 1

They didn't help me 37

They had too many students and not enough time 14

They tried; it was me

Other Teachers, Aides, Tutors in General

Helped me with special classes math/reading/language

Understood me, liked me; cared about me and took time to help; gave me attention

Worked with me in a small group

Gave rewards

8

2

Sixty responses referred to teacher help for students; in general $(\mathrm{N}=50)$, in terms of explaining work $(\mathrm{N}=7)$, preparing students for successive grades $(\mathrm{N}=2)$, for making work interesting $(\mathrm{N}=1)$. 
Twenty-three responses were in terms of teacher support through social relationships. Fourteen responses indicated that one form of support was allowing students extra time to complete work. Fifty-one students reported no teacher help or support. Eight students reported that teachers did try to help, but that students were unable to respond appropriately with acceptance.

The specific assistance of a counselor and teacher aide was noted in this student response:

The midde school counselor talked to me; teacher aides helped me and I had a special reading tutor daily. I improved quite a bit but it ended too soon. I work a lot better with a teacher one-to-one when the teacher is sitting by me. My memory is much longer then. Hands-on training is better for me than bookwork. I can do it (bookwork) and get by, but to really learn and keep it in my memory I need extra help.

The value of a perceived relationship with a regular high school teacher was remarked upon in this student response:

My comparative literature teacher (in the regular program) was good. I hated to leave her class. She explained her work real good. She still talks to me today. I thought she'd never remember me, that I was just another kid.

The absence of relationship was explained in this student response:

They really didn't (help me). I had to reach my friends real quick and reach out to them. Teachers always helped me when I asked but that was rare. I envied people who had teachers as friends.

Table XXV presents student descriptions of relationships with alternative program teachers. 
TABLE XXV

Relationship with Alternative Program Teachers

Student Comments

Response Frequency

Good, great

They care about you, listen, help you with your problems; are understanding and pay attention to you other than teaching

They want to see you learn, get through to you; help you

Same as regular school; fine

They are my friends

They can have these relationships because there are fewer students here

"Good" to "Not so good"

We get to know them better

We call them by their first names

They are like grade school teachers

They are like a family

I do what they ask of me

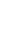


Questions 12 and 25 asked students to comment on their extracurricular participation in both the regular and the altemative program. Table XXVI displays student responses.

TABLE XXVI

Extracurricular Participation in Regular and Alternative Programs

\begin{tabular}{lccccc}
\hline & \multicolumn{5}{c}{ EXTRACURR IOULAR ACTIVITIES } \\
\cline { 2 - 6 } $\begin{array}{l}\text { School } \\
\text { Program }\end{array}$ & $\begin{array}{l}\text { School } \\
\text { Clubs }\end{array}$ & $\begin{array}{c}\text { Performing } \\
\text { Arts }\end{array}$ & Sports & $\begin{array}{c}\text { Sports/ } \\
\text { Arts }\end{array}$ & None \\
\hline Regular & 2 & 19 & 18 & 14 & 28 \\
Alternative & 11 & 4 & 13 & -- & 53 \\
\hline
\end{tabular}

Fifty-three students (65\%) participated in elementary, middle and high school extracurricular activities, while $28(35 \%)$ participated in alternative extracurricular activities. There are clear differences between opportunities in both programs for extracurricular participation. Regular school programs normally include music programs and at the high school level, theatre is an option; alternative programs do not include music and theatre. Sports programs in the alternative are typically extensions of the regular PE program or limited intramurals with other alternatives. The only area in which extracurricular participation increased from the regular to alternative program is in school clubs/organizations; student participation increased by $11 \%$ after alternative enrollment. 
Transition from Regular to Alternative Program

Questions 17-26 emphasized the transition from the reguiar to the alternative high school program.

Table XXVII presents grade-level(s) at which dropout occurred for the sub-sample interviewees.

TABLE XXVII

Grade Level of School Dropout by Alternative Program

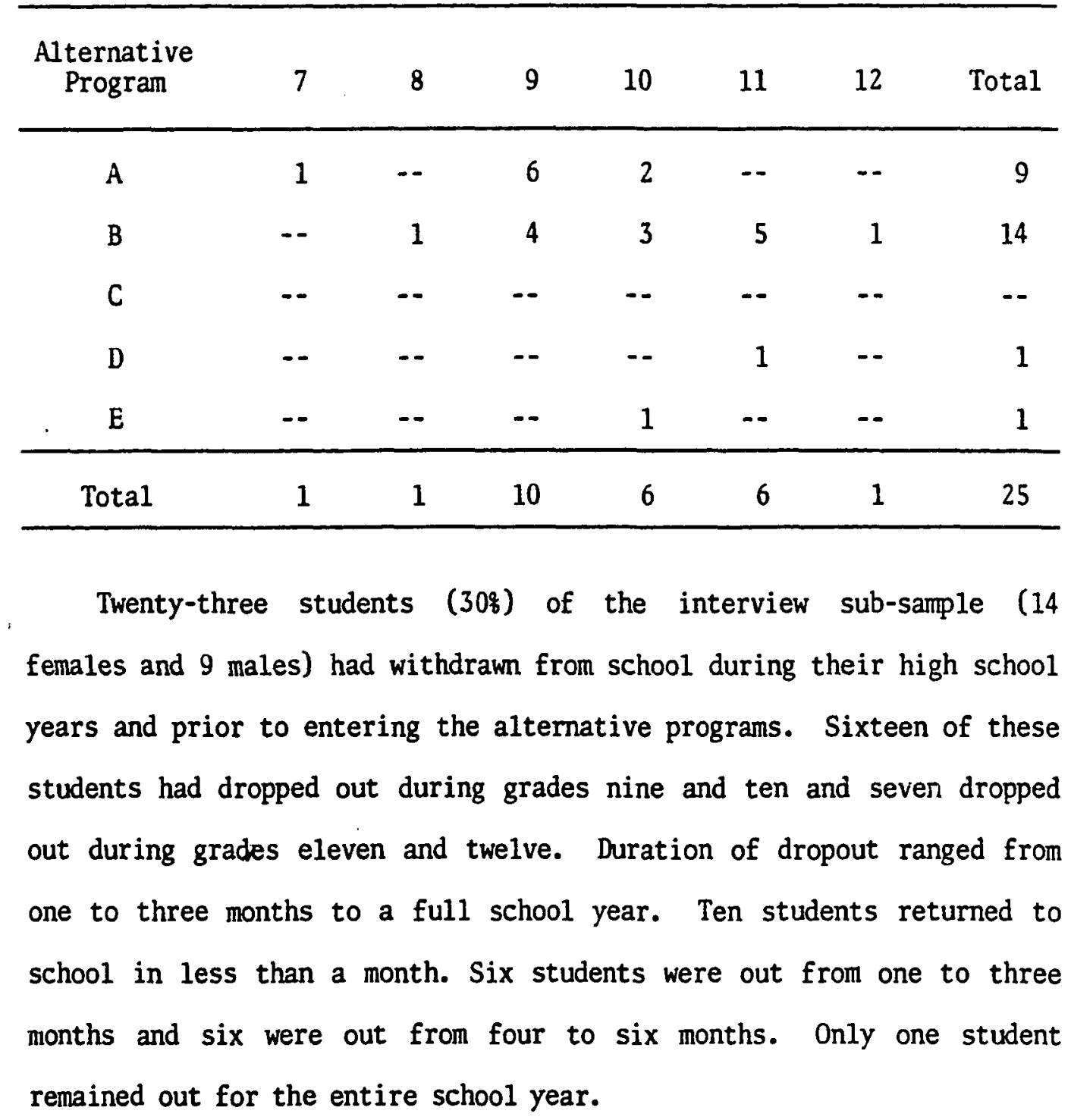


Fourteen of these students returned directly to alternative programs and 10 re-entered the regular high school system, and later transferred to an alternative setting. Of these 24 students, only two withdrew after they had entered the alternative; one after remaining just one quarter and the others after remaining slightly longer than a semester. It is worthwhile to note that withdrawal from a regular high school is a requisite for enrollment in Alternative B; 14 of the twenty-five students who had remained out of school were enrolled in that program.

Table XXVIII displayed student perceptions of their educational performance imnediately prior to alternative entry. Students responded in terms of academic requirements, teacher/student relations, and attendance.

TABLE XVIII

How Students Were Doing in the Regular Program Before Alternative Entry

\begin{tabular}{lc}
\hline Student Corments & Response \\
\hline Grades/Credit/Work & \\
I wasn't doing the work & 17 \\
Low grades & 13 \\
Failing courses & 11 \\
The work was too hard & 3 \\
I was doing okay & 1 \\
Teachers/Students & \\
I didn't like the teachers & 11 \\
Teachers didn't help me & 5 \\
I didn't know anyone & 5 \\
I didn't like the other students & 3 \\
Attendance & \\
I was skipping & 4 \\
I didn't care & 3 \\
\hline Total & 76 \\
\hline
\end{tabular}


Forty-one responses indicated that students were not completing required coursework and therefore receiving low grades and failing courses. Sixteen responses were in terms of teachers; 11 comments stated a dislike of teachers, and 5 suggested that teachers were not helpful. Four responses indicated skipped classes; three indicated a lack of concern or care about the school situation; and one student remarked that though he had transf $\subseteq$ rred to an alternative, he had been doing "all right" in the regular program.

Table XXIX displays frequencies of problems experienced in the regular program prior to transition to the alternative. The problem categories are reported in the literature as common to potential dropouts. 
TABLE XXIX

Problems in the Regular Program Prior to Transition to the Aiternative

\begin{tabular}{|c|c|c|c|c|c|c|}
\hline \multirow{2}{*}{$\begin{array}{l}\text { Problem } \\
\text { Category }\end{array}$} & \multicolumn{5}{|c|}{ Response Frequency by Program } & \multirow[b]{2}{*}{ Total } \\
\hline & $\bar{A}$ & $\bar{B}$ & $c$ & $\bar{D}$ & $\bar{E}$ & \\
\hline Attendance & 21 & 24 & 8 & 16 & 8 & $\begin{array}{c}77 \\
(95 \%)\end{array}$ \\
\hline Friends & 9 & 8 & 1 & 5 & 1 & $\begin{array}{c}24 \\
(31 \%)\end{array}$ \\
\hline Teachers & 18 & 11 & 4 & 9 & 2 & $\begin{array}{c}44 \\
\left(54 \frac{2}{6}\right)\end{array}$ \\
\hline Administrators & 7 & 9 & 2 & 3 & $-\cdot$ & $\begin{array}{r}21 \\
(26 \%)\end{array}$ \\
\hline Suspension & 15 & 16 & 5 & 14 & -- & $\begin{array}{c}50 \\
(638)\end{array}$ \\
\hline School Stressful & 15 & 16 & 6 & 13 & 7 & $\begin{array}{c}57 \\
(73 \%)\end{array}$ \\
\hline Too Many Students & 15 & 16 & 4 & 5 & 2 & $\begin{array}{c}42 \\
(539)\end{array}$ \\
\hline Didn't Fit In & 13 & 10 & 1 & 7 & 4 & $\begin{array}{r}35 \\
(448)\end{array}$ \\
\hline Feared for Safety & 4 & 7 & 2 & 3 & 4 & $\begin{array}{r}20 \\
(25 \%)\end{array}$ \\
\hline Undesirable Class & 7 & 8 & 4 & 4 & 2 & $\begin{array}{r}25 \\
(33 \%)\end{array}$ \\
\hline No Teacher Help & 17 & 18 & 5 & 10 & 4 & $\begin{array}{r}54 \\
(69 \%)\end{array}$ \\
\hline Boredom & 18 & 20 & 6 & 16 & 6 & $\begin{array}{r}66 \\
(87 \%)\end{array}$ \\
\hline Too Far Behind & 15 & 13 & 4 & 11 & 6 & $\begin{array}{r}49 \\
(728)\end{array}$ \\
\hline $\begin{array}{l}\text { Low Grades, } \\
\text { Failing }\end{array}$ & 18 & 12 & 6 & 14 & 7 & $\begin{array}{r}57 \\
(79 \%)\end{array}$ \\
\hline
\end{tabular}


Overall and in rank order, students reported attendance, boredom and disinterest in classwork, failure, a stressful school atmosphere, lack of credits and inability to get enough teacher help, and suspension as their main problems. School safety, problems with administrators and peers, class selection were the least-frequently cited problems. Problems with teachers, large numbers of students at the high school and a perception of not fitting in were more equally mentioned as being or not being problems.

Table XXX displays reasons students gave for leaving the regular program.

TABLE XXX

Reasons for Leaving the Regular High School Program

\section{School-Related}

Wasn't attending 20

Was failing and wanted to continue in school 13

Couldn't cope in the regular program 11

Counseled to leave and enter an alternative 7

Discipline problems at school, e.g., suspension/
expulsion hearing

\section{Personal/Social}

Didn't like regular high school at all 5

I needed a change; was bored with school 5

Came to a new school, heard about the alternative and signed up 4

Friends encouraged me to enter the alternative 4

I needed more help 2

Other problems 2

Thought I could earn credits easier, faster 2

I wanted vocational training 2

I wanted to attend this program since middle school 1 
Responses can be categorized as school-related (academic/behavior) and personal/social. Thirty responses indicate a iack of success with academics; 20 indicate poor attendance; 16 suggest behavior problems. Nineteen responses were stated simply in terms of personal/social needs perceived by students.

Table XXXI lists persons who helped students choose an alternative and make the transition.

TABLE XXXI

Assistance in Transition from Regular to Alternative Program

\begin{tabular}{lc}
\hline Persons who Helped & Response \\
\hline High School counselors & 22 \\
High School administrators & 6 \\
Regular progam staff & 5 \\
Parents & 9 \\
Siblings & 9 \\
Friends & 23 \\
I did it on my own & 16 \\
\hline Total & 90 \\
\hline
\end{tabular}

School personnel, family members, friends, and students themselves were included in the list of persons who supported the transition from regular to alternative programs. The largest category of responses $(\mathrm{N}=33)$ cited assistance of school personnel. The 57 remaining 
responses identified friends $(\mathrm{N}=23)$, family $(\mathrm{N}=18)$ and the student himself $(\mathrm{N}=16)$ as key faciilitators of the transition.

Table XXXII presents what the students hoped to gain from their alternative entry.

\section{TABLE XXXII}

Student Goals for Alternative Program Participation

\begin{tabular}{lc}
\hline Goals & Response \\
\hline Graduation & 44 \\
Credits & 20 \\
Better grades & 9 \\
Help to go to school and stay in & 8 \\
Education & 5 \\
Help in my work & 3 \\
Self-respect & 3 \\
Get myself together & 2 \\
Catch up & 2 \\
Inprove & 2 \\
Change & 2 \\
Grades, skills, communication with teachers; & 103 \\
\hline easier classes; attention from teachers & \\
\hline Total & $2 a c h$ \\
\hline
\end{tabular}


Twenty-seven of the student respondents who mentioned graduation included related goais: 9 wanted to return and graduate from their regular high school program, 15 looked forward to college, 1 hoped for a job, and 2 intended to enter the service. Forty-seven responses indicated academic impovement as a goal. Twelve suggested more personalized intrinsic goals such as gaining an education $(\mathrm{N}=5)$, attaining self-respect $(\mathrm{N}=3)$, or general self-improvement $(\mathrm{N}=4)$.

One student remarked:

I didn't know, but I knew I wanted to graduate. After I got here I felt a lot of people cared and thought I could graduate and people would help me find out what field I could go into if I wanted to be helped. They told me that I had to be helped to do it.

Another said:

Here they made me want to come to school, just like a family. It's so close; we go on field trips together. This place is really together, a good alternative. If you really want to learn, graduate and be somebody, this program can help you. They teach a lot you couldn't learn outside. You need skills to get along. You can't deal as easily in the outside world without an education.

When asked where they might be if not enrolled in the alternative program, students responded as follows: 
TABLE XXXIII

Placement If Not Enrolled in Alternative Program

\begin{tabular}{lc}
\hline Student Comment & Response \\
\hline Probably dropped out of school & 41 \\
In the regular program & 12 \\
In another alternative program & 11 \\
In bad shape in the regular program & 6 \\
Working & 6 \\
In high school continuation & 3 \\
I don't know & 2 \\
\hline Total & 81 \\
\hline
\end{tabular}

Forty-one students said they would probably be out of school. Thirty-two said that even without their current alternative program, they would be enrolled in some kind of educational program. Six thought they would be working, and two students had no response. 


\section{CHAPTIER V \\ SUMMARY, CONCLUSIONS AND RECOMMENDATIONS}

FOR FURTHER RESEARCH

The summary and conclusions are presented in response to these questions: 1) How does the district's alternative high school population fit traditional descriptions of high-risk? 2) How did the

students come to the alternatives? and 3) What patterns can be identified from alternative students' educational experiences in the district?

The nature of the "fit" between the study population and literature-related characteristics (both personal/social and school-related) remains descriptive. Discussion of the findings is presented in terms of the study population, and also with reference to each of the five sample programs. Patterns of educational experiences are discussed in terms of historical data with reference to student interview responses. The discussion emphasizes how students who have spent the majority of their educatonal careers within the district came to the alternative programs. Recommendations for further research are based upon those conclusions which address the relationships among educational experiences, and suggest hypotheses from which the high-risk perspective may be examined in depth. 


\section{Summary}

How does the alternative population fit traditional descriptions of high-risk?

Personal/Social Characteristics. Overall, the alternative program population most clearly matches traditional personal/social descriptions of potential dropout/high-risk in terms of sex representation, between school district mobility, and because they have experienced some period of dropout.

Fifty-four percent of the population is male, $46 \%$ is female and this ratio is consistent across all grades and programs except one school within a school in which twice as many females as males were enrolled.

When entry to the district, duration of 1983-84 alternative enrollment, and end-of-year placement are considered, the population can be characterized as mobile. Fifty-two percent of the sample population transferred into the district after grade two, and $25 \%$ entered during their high school years. During 1983-84, the average alternative program enrollment duration was 5.5 months, (slightly more than one semester); only $29 \%$ of the whole group remained enrolled in the alternative for the entire school year. By the end of 1983-84, $30 \%$ of the students had dropped out. In terms of within-district mobility, $33 \%$ of the alternative population have changed schools more frequently than the district average.

The "high-transfer/mobility" descriptor is complex because it has multiple operational definitions. The data suggest that some students remain continuously enrolled in educational progrms, but they change 
schools frequently; others enroll for short periods of time, drop out for longer durations, and repeat the process.

A large number of eleventh and twelfth graders are enrolled in alternatives than the literature would suggest; 658 of the sample population are in grades eleven and twelve while $35 \%$ are in grades nine and ten. If dropout more often occurs during the eight/nine transition to high school or between grades nine and ten, it is unlikely that the alternative programs in this study re-capture those students. Dropout rates from the alternative programs were similar across grade levels; $30 \%$ of ninth graders, $31 \%$ of tenth, $26 \%$ at grade eleven and $33 \%$ at grade twelve withdrew during the 1983-84 school year.

Minorities are not over-represented in the sample programs; $19 \%$ of the enrollment is ethnic minority while $26 \%$ of the total high school population is minority. The district's ten high schools had percentages of minority enrollment ranging from 12-51\%; seven regular high schools had a higher percentage of minority enrollment than the entire five school alternative sample. According to these data, the alternative programs differentially serve the district's potential dropout population; they do not attract a minority population proportional to the number of minority students who drop out.

In terms of low socio-economic status (measured by participation in Free/Reduced lunch programs) $31 \%$ of the eligible alternative students have qualified. It is important to remember that these figures do not reflect the entire sample because $28 \%$ of the total population (Program C) attend school in the evening and have no opportunity to be counted in terms of Free/Reduced Lunch application. 
School-Related Characteristics. The school-related descriptors emphasize achievement and behavior. Seven percent of the sample population had been retained in grade during district enrollment. According to achievement test records, $82 \%$ of the sample population passed language usage competencies, $75 \%$ passed reading and $58 \%$ passed math. Differences in grade-level enrollment in the alternatives may be part of the explanation for his performance; one could expect that twelfth graders (who make up the largest percentage of the alternative population) would have had more opportunities to take and pass the tests. While there are still many students who have not passed among the sample population, these data suggest that, as a group, the population is achieving. From the literature reviewed, one would not expect that $75 \%$ of the group would have passed a reading competencies test becuase reading is described as the potential dropout's area of lowest achievement.

Perhaps a better indicator of basic skills achievement is the group's history of supplementary/compensatory program participation. Low achievement and/or performance (typically two years below grade level) are key criteria for identification and over half of the same population (528) was identified for one or more supplementary programs. Twenty-eight percent of the sample population were identified for Chapter. I and 348 were identified for Special Education. Identification for special education may be for academic or emotional disability; these data do not discriminate those differences. Ten percent of the population had participated in other district alternative programs prior to the 1983-84 school year. 
Forty-six percent of the alternative population had experienced at least one suspension during district enrollment. The school-related categories, in frequency rank-order, are Behavior with Staff $(\mathrm{N}=83)$, Attendance $(\mathrm{N}=74)$, and Behavior with Other Students $(\mathrm{N}=71)$. Fifty percent of the Behavior with Staff suspensions were due to insubordination; $50 \%$ of the Attendance suspensions were for truancy; and $63 \%$ of the Behavior with Students suspensions were for fighting.

A high-risk perspective calls for attention to those variables over which schools can reasonably be expected to have an impact. In order to consider the usefulness of such a perspective, some of the data (particularly personal/social characteristics) are necessarily de-emphasized. This approach is not to deny the reality of personal characteristics, but is intended rather to recognize them as the constants they are, and to focus instead upon those experiences directly amenable to educational effects; for example, achievement, school-related behavior and school status perceptions.

In terms of educational performance, at the end of the 1983-84 school year, the alternative sample would not be characterized as particularly low-achieving. However, other of the group's educational experiences suggest otherwise. Fifty-two percent have had some history of supplementary and compensatory educational support during district enrollment. The remaining $48 \%$ have none. If the euphemism "fallen through the cracks" applies, it may be this group it fits.

In terms of school-related attitudes and discipline, historically, the largest suspension category for the group has been Behavior with 
Staff, most often coded as insubordination. Given the critical importance of the teacher-student relationship as reported by interviews with students who had a nine-to-twelve-year history in the system, it is reasonable to consider the distribution of this cateogry of suspension offenses before and after transition to the alternatives. The issue of insurbordination is related to issues of personal control. Blum and Spangehl (1983) point out the need for students to develop a sense of control to support their active particiption in education, but the alternative interview group has made clear its dependency upon the teacher relationship. Opportunities for control certainly exist within alternatives--in terms of course selection, a shorter, more manageable instructional timeframe, and the increased participation in extra-curricular school clubs. In the regular high school program, it is more likely that only an independent learner will achieve the level of control required to ensure a support for an active role in education. Within the alternatives, this level may be a long-term goal, but students comfortably report their current level of need for instructional and personal help and attention. One way to interpret the students' responses is in terms of a "cooperative" sense of control they share with their alternative program teachers.

Group Characteristics and Program Populations. Though all five programs selected for the study are considered alternatives for potential dropouts, the data reveal that program groups fit the traditional descriptors differentially.

Program A has the most balanced grade-level representation, a relatively equal number of male and female students, and the highest 
percentage of both low-SES students, and students enrolled in the district since K-2. Program A enrolled no ethnic minorities during 1983-84. Students enrolled during 1983-84 had the longest mean enrollment duration ( 7 months), and the program retained the largest percentage of its enrollment at the end of the 1983-84 school year. In terms of achievement, Program A had the highest percentage of student passing both the district math and laguage usage tests, as well as the highest percentage of students with no previous identification for supplementary/compensatory progranming.

The majority of students enrolled in Programs B and C are eleventh and twelfth graders, numbers of males and females are relatively equal, and both programs have representaton from all five ethnic minorities in the district. A third of Program B students are considered low SES based on Free/Reduced lunch applications. Over half of the alternative students who entered the district during their high school years are enrolled in Programs B and C. Program C had the shortest mean enrollment duration during 1983-84 (four months), and the greatest percentage of dropout during the school year. Program C tied with Program A for the highest percentage of students passing the district's language usage test.

Programs $D$ and $E$ have the highest percentages of ninth and tenth grade students, and the second highest percentage of K-2 enrollees. Both programs are represented by four minority groups (neither program has Oriental representation). Both Programs had a mean enrollment duration of six months during 1983-84, and approximately half of the students in both Programs remained enrolled at the end of the year. 
Programs D and E have the greatest percentage of students with previous identification for supplementary/compensatory programming.

In Program D, males and females are relatively equally represented; Program E has a higher female enrollment. Program $D$ had the lowest percentage of low-SES students. Program E had the lowest percentage of students who had been retained in the district, the lowest percentage of dropouts, the greatest percentage of students who have passed the district's reading test, and the second largest percentage of $\mathrm{K}-2$ enrollees.

The ninth and tenth graders in the study sample were more often enrolled in schools-within-schools, and tended to remain in the alternative program for fewer months of the school year. Eleventh and twelfth graders were more often enrolled in the separate and unique alternative programs, typically remained enrolled there somewhat longer than ninth/tenth graders, and when they dropped out, it more often occurred at grade twelve.

\section{How did Students Come to the Alternative Programs?}

Approximately half of the alternative students spent the majority of their educational careers in the district. Historical data for this group suggest different routes from regular to alternative programs. Figure 5 presents a long-range perspective on the transition. 


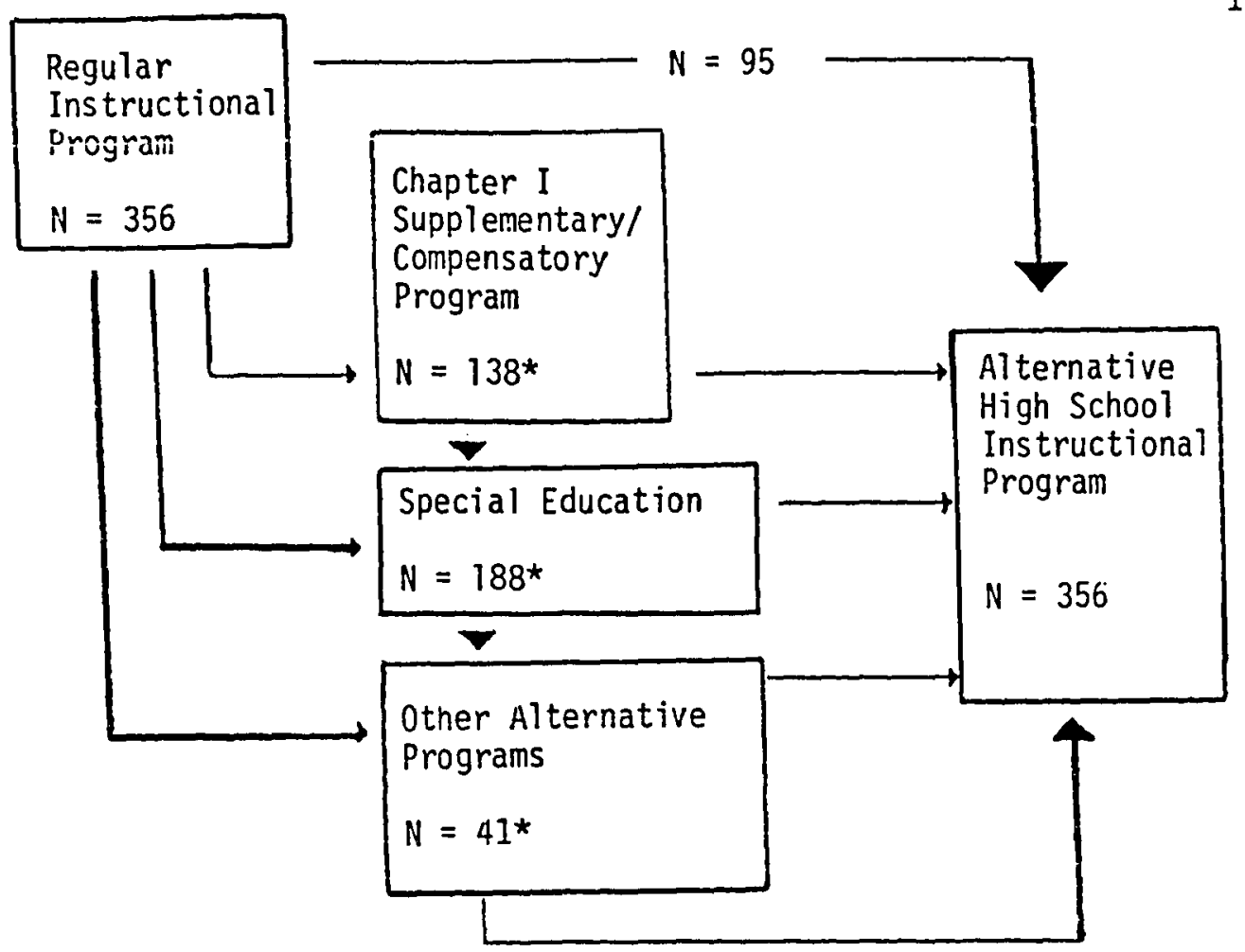

Figure 5. Educational career experiences of $\mathrm{K}-2$ entrants to the district

Student interviews described a short-range version of the transfer from regular to alternative high school. Students reported that they left the regular high school after long periods of non-attendance which they attributed to a combination of an increasing disaffection with high school, feelings of stress and low esteem induced by falling farther behind in schoolwork, and the perception that they were too far behind to ever catch up.

Perceiving themselves without high school support to continue in the regular program, students said they were encouraged by friends, counselors or family members ( $86 \%$ of the interview sample lived with one or both parents) to leave the regular program and transfer to an alternative. The process of transition was highly variable, indicating 
a lack of standardized administrative support for the transfer to aiternatives. Nor were students aware of the array of options available within the district. Interviewed students who were attending separate and unique alternative programs sometimes reported a lack of knowledge about school-within-a-school alternatives available in their regular high school. This absence of information is congruent with the reported impression of being without advocacy in a high school setting perceived to be too complex for some students to negotiate by themselves. The few students knowledgeable about more than one or two alternatives had typically attended one of them previously. If alternative entry is considered part of a track, it was a self-selected one. Selection and placement in alternatives was more often a result of personal and family initiative rather than a planned appropriate placement based on a formal assessment of students' needs.

What Patterns can be Identified from Students' Educational Experiences in the District?

The students interviewed perceived themselves as of average ability but they qualified their descriptions with comments regarding personal attitudes and behaviors which affected achievement, e.g., "I'm an average student, but I don't like to work very hard." School in general (and it is important to note that comments were made during enrollment in alternatives) was at best a requirement to be met; the most conmon personal goal among the interviewees was simply graduation. Success in both regular and alternative programs was defined by the extrinsic reward of grades; only five of the 81 students interviewed mentioned rewards which could be considered more 
intrinsically satisfying, e.g., staying in school and doing the work, improving one's self-respect and one's attitude about learning in general.

Teachers were perceived as the most critical component of the educational experience. While the instructional "helping" relationship and its consistent contribution to student success in school was often noted, a more personalized teacher-student relationship was mentioned even more frequently. Students often described their alternative teachers as "like grade school teachers" who were remembered as being helpful, understanding and attention-giving. Students perceived regular high school teachers as the least helpful and least supportive of any they had encountered in their educational careers; but they qualified their criticism with an explanation that the curricular/ instructional schedule of the regular high school precludes the regular teacher from providing either consistent instructional support or regular personalized attention. Large numbers of students and multiple classes made for few opportunities to develop the kinds of relationships the alternative students reported they needed.

In addition to fewer students and smaller classloads in an alternative setting, students described effective teacher practices such as in-class support for completion of work and an individualized instructional pace; these practices convinced students that the alternative program coursework, while just as difficult as that of the regular program, was more manageable (and thereby easier) due to the alternative program delivery and support modes. Much alternative instruction is delivered in a short timeframe, for example, in 4-6 week 
cycles. This practice seemed to meet student-reported needs for an individuaiized pace, support, and put the extrinsic grade reward within reach. The 1983-84 enrollment data indicate that alternative students attended school for variable periods of time within the school year. Alternative programs are the only public school settings which are organized to allow students an opportunity to meet coursework requirements within non-standard timeframes.

In describing educational experiences prior to alternative program entry, students recalled similarly positive experiences with teachers and support staff during specialized programs such as Chapter I reading or the Special Education Resource Center. The only differences between the earlier student-staff relationship and that of the alternative were in terms of consistency; in the regular school program, teacher support and attention occurred more often in small and specialized settings and in the alternative the support and attention were provided consistently by all program staff. The interview responses describe an alternative instructional delivery mode that is strongly teacher-dependent, with greater opportunities for choice in course selection, and consistent provision of support to meet coursework requirements.

The historical data illustrate that the alternative students were identified early in their careers for programs designed to improve their educational performance and achievement. The interview data suggest that there was an affective dimension to those experiences as well. Students who have left regular schools have chosen alternatives which provide a personalized and caring instructional delivery for the total high school program. The students did not report a 
pre-alternative school awareness of these needs, nor suggest that they had articulated them during their tenure in regular programs. Their comments suggest that they have not developed the skills required to perform satisfactorily as independent learners. These students believe in, and are dependent upon, the kind and level of individualized help and attention they receive in the alternative programs.

\section{Conclusions}

1. The historical data indicate that propositions for high-risk differentially describe the alternative student group. The 1983-84 alternative high school population best fits traditional personal/social descriptors of high-risk in terms of the following: (1) Mobility: About half of the student sample entered the district after the primary grades; $25 \%$ entered during high school, and, attendance at the alternatives was variable; most students were not enrolled for the entire school year; (b) Approximately equal numbers of male and female students were enrolled; (c) Approximately 30\% were identified for low SES. The population fits the traditional description less well in these areas: (a) Grade-level: Larger numbers of eleventh and twelfth graders are enrolled than the literature would suggest; (b) Minorities are under-represented.

The 1983-84 alternative population best fits school-related descriptors in these ways: (a) Though generally higher-achieving than the literature would suggest (particularly in language usage and reading), over half participated in compensatory/supplementary and/or other alternatives earlier in their careers; (b) $46 \%$ of the students 
have been suspended at least once during district enrollment.

2. Schools can reasonably be expected to have an impact in these three areas of high risks: educational performance, school-related behavior, and school status perceptions. The system has responded formally to over half of the alternative population by identifying them for compensatory/supplementary programs early in their careers. It is possible that the educational performance benefits are reflected in the group's achievement level. Students are able to recall the personalized quality of those experiences and report that alternative programs offer the consistency of that personalized approach. Students recognize that the present curricular/instructional organization of the high school does not provide the level of help and attention they need.

3. The fact that over half of the alternative population has been in the district since $\mathrm{K}-2$, that half of the total group (including students who entered after their primary years) were previously identified for supplementary programs suggests a need for articulation among program experiences and a commitment to ensure ongoing forms of consistent academic and affective support for student who are identified. A method to best produce these outcomes is not through creation of additional ad hoc programs, but rather through improvement in coordination of both form and content of instructional experiences. A system-wide contribution can occur through a commitment to guaranteeing that elements of more-personalized instructional processes are implemented throughout the district's regular educational program.

The data suggest that a coordinated effort to improve achievement and behavior can affect not only academic educational performance but 
also the acquisition of positive status for students within the school organization and a continuing comitment to remaining in school.

4. Teachers who help students complete their classwork, who deliver personalized instruction, who communicate an interest in and caring for individual students were identified as the most critical components of the educational experience. At the same time, the data indicate that "Behavior with Staff" (most often defined as insubordination) was the chief reason for suspension due to school-related behavior. It is reasonable to conclude that increased opportunities for high-risk students to work with more responsive staff will lead to a decline within this suspension category.

5. Students typically came to the alternatives from a regular high school setting. They left after long periods of non-attendance which they attributed to increasing disaffection, feelings of stress and low esteem due to failure in a high school program. Perceiving themselves without support to achieve success in the regular program, they were encouraged by friends, counselors and their families to transfer to an alternative. Students more often selected and arranged for transition themselves, with minimal assistance from regular school programs and staff.

6. The guidance of naturalistic inquiry methods was particularly useful in this study. The 11 propositions for high risk served to bound the data collection and allow a focus on traditional descriptors within categories identified as more or less susceptible to an educational impact. While the data collection was specified in advance, according to a conceptual framework derived from the literature, the analysis of 
the descriptive data were not fixed a priori. This allowed the researcher an opportunity to examine traditional characteristics from a variety of perspectives. This kind of flexibility served to delineate the usefulness of at least two key descriptors--transfer/mobility and student achievement--by suggesting that both are susceptible to more than one interpretation, and that educational responses might be more effective if they can be designed to meet specific needs rather than generalized group characteristics.

\section{Recommendations for Further Research}

A goal of this study was to investigate the educational histories of students prior to their alternative high school entry. The purpose of the investigation was to generate data which might be useful for early identification of potential dropouts, to gain insight into possible relationships between regular and alternative educational experiences, and to examine the usefulness of a focus on high-risk descriptors which schools can reasonably be expected to impact. Recommendations for further research address each of these issues.

1. Teachers were identified as the key components of successful educational experiences. An investigation into the nature, practice, trainability and assessment of "personalized instruction" is an appropriate subject for further study. The interview data suggest that these practices are not limited to alternative program teachers; students have experienced them in both regular and supplementary instructional programs. If more precise definitions of the elements of personalized instruction can be determined and observed, it will be 
possible to examine its effect on educational outcomes.

2. Because of the diversity of educational programs within a district, an investigation should be conducted to determine relationships among programs in terms of instruction (both content and process) and expected outcomes. It may be possible to provide better articulation among various educational experiences for high-risk students in order that they are treated with the consistency their histories suggest they require.

3. The data collected and summarized for this study are susceptible to a number of related and useful investigations: a) It is important to determine whether there are significant differences in achievement and behavior for that portion of the alternative population who have spent their entire educational careers within the district and never been identified for supplementary program particiption; b) School-related characteristics of high risk (particularly in terms of supplementary program identification and alternative enrollment) should be examined for a group of students who dropped out of the regular high school program and have not returned; c) Comparable data about a regular high population should be sumnarized and comparisons between regular and alternative groups made in order to better describe the magnitude and possible significance of differences. 
Abel, Billy LaRue. (1970). A study of hrmanizing and dehumanizing facts in the secondary school environment as perceived by a selected sample of dropouts. (Doctoral dissertation, Indiana University, 1970). Dissertation Abstracts International, 31, 5920A-5921A.

Allen, Dane Shelton. The relationship between school-agency cooperation, selected school characteristics, and dropout rates in selected public secondary schools in Missouri. (Doctoral dissertation, University of Southern Mississippi, 1980). Dissertation Abstracts International, 41, 4549A-4950A.

Altbuch, Peter, \& St. George, Nicholas. (1981). An educational alternative for delinquent offenders; Storms Street School. Education, 101, 226-230.

Argyris, Chris. (1974). Alternative schools: A behavioral analysis. Teachers College Record, 75(4), 429-452.

Arnove, R.F., \& Strout, T. (1980). Alternative Schools for Disruptive Youth. (ERIC Document Reproduction Services No. ED 162 413)

Arthur D. Little, Inc. (1979). Alternative education options. Washington, D.C.: Author. (ERIC Document Reproduction Service No. ED 178 792)

Babbie, Earl R. (1975). The Practice of Social Research. Belmont, CA: Wadsworth.

Bachman, Jerald G., Green, Swayzer, \& Wirtanen, Ilona D. (1971) Youth in Transition: Volume III, Dropping Out--Problem or Symptom? Ann Arbor, Michigan: University of Michigan Institute for Social Research.

Barr, Robert. (1978). Magnet school curriculum. Unpublished manuscript, Indiana University, College of Education, Bloomington.

Barr, Robert, Colston, B., \& Parrett, W.H. (1977). The effectiveness of alternative public schools. Viewpoints, $\underline{53}$ (4), $1-20$.

Beach, Christine, \& Halverson, Bret. (1981). Educational services for at risk adolescents: A program evaluation report. Long Island City: Advocates for Children of New York.

Beal, Philip E., \& Noel, Lee. (1980). What works in student retention (Report of a joint project of the American College Testing Program and the National Center for Higher Education Management Systems). Iowa City, IA: American College Testing Program. (ERIC Document Reproduction Service No. ED 197 635) 
Beck, Lisa \& Muia, Joseph A. (1981). A portrait of a tragedy: Research findings on the dropout. The High School Journal, 64, $65-72$.

Beebe, Cora P. \& Evans, John W. (1981). Clarifying the federal role in education. In Robert A. Miller, (Ed.), The Federal Role in Education: New Directions for the Eighties. Washington, D.C.: Institute for Educational Leadership.

Berlowitz, Marvin J. \& Durand, Henry. (1976) School Dropouts or Student Pushouts: A Case Study of the Possible Violations of Property Rights and Liberties by the de facto Exclusion of Students from the Public Schools. (ERIC Document Reproduction Services No. ED 143 898)

Biddle, Bruce, D. J., Anderson, D. I., Bank, Barbara, Keats, Daphne M., \& Keats, John A. (1981). The structure of idleness: In school and dropout adolescent activities in the U.S. and Australia. Sociology of Education, 54, 106-119.

Bledsoe, Joseph C. (1959). An investigation of six correlates of student withdrawal from high school. Journal of Educational Research, 53, 3-6.

Block, Eve E. (1978). Failing Students Failing Schools: A Study of Dropouts and Discipline in New York State. New York: New York Civil Liberties Union, 1978, 215. (ERIC Document Reproduction Services No. ED 160674 )

Blum, Mark E. \& Spangehl, Stephen D. (1982). Developing Educational Programs for the High Risk Secondary School and College Student. (ERIC/CUE Urban Diversity Series, \#80). New York, NY: ERIC Clearning House on Urban Education, Institute for Urban and Minority Education.

Bogdan, Robert C. \& Biklen, Sari Knopp. (1982). Qualitative research for Education: An introduction to theory and methods. Boston: Allyn \& Bacon.

Bradburn, Norman M. \& Sudman, Seymour. (1979). Improving interview method and questionnaire design. San Francisco: Jossey-Boss.

Brain, George B. (1974). Administrative and supervisory practices affecting the school dropout. In Daniel Schreiber (Ed.), The school dropout (135-143). Washington, D.C.: National Education Association.

Bredemeier, Harry C. (1968). Schools and student growth. Urban Review, 2, 21-27.

Broad, Lyn. (1977). Alternative schools: Why, what, where, and how much? Arlington, VA: National School Public Relations Association. 
Brookover, Wilbur B. \& Erickson, Edse1 L. (1969). Society, schools, and learning. Boston: Allyn \& Bacon.

Brown, B. Frank (1973). The reform of secondary education: A report to the public and the profession. (National Commission on the Reform of Secondary Education). New York: McGraw-Hill.

Byerly, C.C. (1953). How can a school increase its holding power of youth? NASSP Bulletin, 37, (194), 186-189.

Carlisle, John C. \& Williams, L.A. (1938). What pupils are being eliminated. The Clearing House, 13, 233-234.

Carter, Launor F. (1984). The sustaining effects study of compensatory and elementary education. Educational Researcher, 13, 4-13.

Center for New Schools. (1972). Strengthening alternative high schools. Harvard Educational Review, 42, 313-350.

Cervantes, L. (1965). The Dropout: Causes and Cures. Ann Arbor, Michigan: University of Michigan.

Cheng, Maisy \& Larter, Sylvia. (1979). Study of returning students; Part 2. The attitudes of principals, guidance counselors, teachers, and students to returning students (Report 149). Toronto, Ontario: Toronto Schools Research Department. (ERIC Document Reproduction Service NO. ED 188 028)

Children's Defense Fund of Washington. (1974). Children Out of School in America. Washington, D.C.: Author.

Cicoure1, Aason V. \& Kitsuse, John I. (1963). The educational decision-makers. Indianapolis, IN: Bobbs Merrill.

Combs, J. \& Cooley, W.W. (1968). Dropouts: In high school and after high school. American Educational Research Journal, 5, 343-363.

Conant, James B. (1961). Slums and Suburbs. New York: McGraw Hill.

Conant, James B. (1967). The Comprehensive High School. New York: McGraw Hill.

Cook, Edward S., Jr. (1956). An analysis of factors related to withdrawal from high school prior to graduation. Journal of Educational Research, 50, 191-196.

Counts, George S. (1922). The selective character of American secondary education. Chicago, IL: University of Chicago Press.

Dauw, Edward G. (1972). Separate schools for potential dropouts. Educational Leadership Research Supplement, 5 , 330-340. 
Deal, Terrence E. (1975). An organizational explanation of the failure of alternative secondary schools. Educational Researcher, 4, (4), $10-16$.

Deal, Terrence E. \& Nolan, Robert R. (1978) An overview of alternative schools. In Terrence E. Deal \& Robert Nolan, (Eds.), Alternative Schools: Ideologies, Realities, Guidelines. Chicago, IL: Nelson Hall.

Degracie, James S. (1974). The picture of a dropout. Mesa, AZ: Mesa Public Schools, Department of Research and Evaluation. (ERIC Reproduction Service No. ED 110 777)

Doob, Heather. (1977). Evaluations of Alternative Schools. Arlington, VA: Educational Research Services.

Duke, Daniel L. (1976). Challenge to bureaucracy: The contemporary alternative school. The Journal of Educational Thought, 10, (1), 34-48.

Duke, Daniel L. (1978-79). Investigating unanticipated educational phenomena; A special plea for more research on alternative schools. Interchange, 10, (1), 67-79.

Duke, Daniel L. (1978). The retransformation of the school. Chicago, IL: Nelson Hall.

Duke, Danie1 L. \& Mazio, D. (1978). How effective are alternative schools? A review of recent evaluations and reports. Teachers College Record, 79, 461-483.

Easley, Edgar M. (1971). Findings of a dropout prevention study of the Spartanburg city schools and resultant recommendations: Final Report. Spartanburg, S.C.: Communication and Education Services. (ERIC Document Reproduction Service No. ED 060 462)

Education USA. (1972). Schools Rescue Potential Failures. (Special Report).

Eeles, Ronald A. (1970). School related factors present in grade six that predict grade eleven and twelve dropouts. (Doctoral dissertation, University of Oregon, 1970). Dissertation Abstracts International, 31, 3263A-3264A.

Eels, Walter C. (1938). Why secondary school pupils leave school. The Clearing House, 12, 525-528.

Evraiff, William (1957). How different are our dropouts? NASSP Bulletin, 41, (226), 212-218. 
Fantini, Mario. (1974). Alternative schools and humanistic education. Social Education, 38, 243-247.

Fantini, Mario D., (Ed.). (1976). Alternative education:A source book for parents, teachers, students, and administrators. Garden City, N.Y.: Doubleday.

Fenstermacher, Gary. (1977). To what is alternative education an alternative? In John Goodlad, Gary D. Fenstermacher, Thomas J. LaBelle, Val D. Rust, Rodney Skager, \& Carl Weinberg, (Eds.). The conventional and the alternative in education. Berkeley, CA: McCutchon.

Gadwa, Karol, Bolck, Debora, Bryan, Elizabeth \& Christensen, John. (1983). School Dropout Study:A Final Report. Lynwood, WA: Edmonds School District, Student Services Department.

Ghory, Ward J. \& Sinclair, Robert L. (1978). Views from the margins: Student perceptions of educational environments in public alternative high schools. (ERIC Document Reproduction Service NO. ED 160 693)

Gibboney, Richard A., Langsdorf, Michael 0., \& Smith, David M. (1975). The career intern program: Preliminary results of an experiment in career education. (Volume 1). Philadelphia, PA: Opportunities Industrialization Centers of America. (ERIC Document Reproduction Service NO. ED 117 351)

Glatthorn, Allan. (1975). Alternatives in education:Schools and programs. New York: Dodd, Mead.

Gold, Martin \& Mann, David W. (1982). Alternative schools for troublesome secondary students. The Urban Review, 14, 305-316.

Goodyear, Rodney K. (1974). A review of psychologically oriented interventions for potential dropouts. Journal of Educational Research, 67, 347-350.

Gowan, John Curtis. (1971). School Dropouts and Potential Dropouts. In Lee C. Deighton, (Ed.), Encyclopedia of Education, Volume 2, (477-481). New York, NY: Macmillan.

Gragg, William L. (1949). A dropout of a high school graduate. Education Digest, 15 (1), 30-31.

Grant, W. Vance \& Eiden, Leo J. (1980). Digest of Education Statistics 1980. (Office of Educational Research and Inprovement, U.S. Department of Education). Washington, D.C.: U.S. Government Printing Office. 
Grant, W. Vance E Eiden, Leo J. (1983). Digest of Education Statistics 1982. (National Center for Education Statistics). Washington, D.C.: U.S. Govermment Printing Office.

Graubard, Allen. (1973). Free the children: Radical reform and the free school movement. New York: Pantheon.

Greene, Bert I. (1966). Preventing student dropouts. Englewood Cliffs, NJ: Prentice Hall.

Gregory, Thomas B. \& Smith, Gerald R. (1982). The impact of social climates: Differences between conventional and alternative schools. Educational Horizons, 60, 83-89.

Guba, Egon C. (1978). Toward a methodology of naturalistic inquiry in educational evaluation. Los Angeles, CA, University of California, Center for the Study of Evaluation.

Ha11, C. W. (1929). A study of group of early leaving high school pupils. Educational Research Bulletin, 8, 4-9 and 14-19.

Hamilton, Stephen F. (1981). Alternative schools for the 80's; Lessons from the past. Urban Education, 16, 131-148.

Hargreaves, David H. (1967). Social relations in a secondary school. London: Routledge \& Kegan Pau1.

Harris, J. John, Fields, Richard, \& Carter, David G. (1983). A legal and historical perspective on suspension and its effect on inequality in education. (ERIC Document Reproduction Service No. ED 235 258)

Hawaii State Department of Education. (1968). Secondary student status survey 1967-68, (Part 1). (Report No. HSDE OR RR 65). Honolulu, HA: Author. (ERIC Document Reproduction Service No. ED 029 320)

Hicks, J. B. (1969). All's calm in the crow's nest. American Education, $\underline{5}, 9-10$.

House, Ernest R. (1980). Evaluating with Validity. Beverly Hills, CA: Sage Publications.

Howard, M.A.P. \& Anderson, R.J. (1978). Early identification of potential school dropouts: A literature review. Child Welfare, 57, 221-231.

Howard, B. (1978). Dropouts: Prevention and rehabilitation; Schools rescue potential failures. Washington, D.C.: National School Public Relations Association. 
Huntington Associates, Inc. (1982). Youth at risk and work: New York's Investment in the future. A working paper for the Comittee for Public/Private Cooperation for an Institute. New York: Author. (ERIC Document Reproduction Service No. ED 221 634)

Hyman Herbert H., Cobb, William J., Feldman, Jacob, Clyde W., \& Stember, Charles Herbert. (1954). Interviewing in social research. Chicago, IL: University of Chicago.

Irvine, Russell W. (1979). Structure of school, personality and high school dropouts. Journal of Negro Education, 48 (2), 67-72.

Jablonsky, Adelaide, (Ed.). (1970). The School Dropout: A Review of the ERIC Literature. (ERIC IRCD Urban Disadvantaged Series, \#9). New York: Columbia University, ERIC Clearinghouse on the Urban Disadvantaged. (ERIC Document Reproduction Service No. ED 035 778)

Jablonsky, Adelaide, (Ed.). (1974). Dropouts: An annotated bibiography of doctoral dissertations. (ERIC IRCD Doctoral Research Series \#8). New York: ERIC Clearninghouse on the Urban Disadvantaged. (ERIC Document Reproduction Service No. ED 096 362)

Janssen, K.D. Cole. (1974). Matters of Choice: A Ford Foundation Report on Alternative Schools. New York:Ford Foundation.

Johnson, Clarence D. \& Hopkins, Bobby R. (1972). Orange County dropout prediction study. Santa Ana, CA: Orange County Department of Education. (ERIC Document Reproduction Service No. ED 075 729)

Kaplan, Jay L. \& Luck, Edward C. (1977). The dropout phenomenon as a social problem. Educational Forum, 42, 41-56.

Ke1ly, Delos H. (1973). Track assignment and student mobility patterns as barriers to equality of educational opportunity: A review of recent research. Contemporary Education, 45, 27-39.

Kelly, Delos H. \& Pink, William T. (1971). Social origins and school failures: A reexamination of Cohen's theory of working class delinquency. Pacific Sociological Review, 14, 413-430.

Kelly, Delos H. \& Pink, William T. (1973). Social origins, school status and the learning experience. Pacific Sociological Review, 16, 121-134.

Kerlinger, Fred N. (1964). Foundations of behavioral research. New York: Holt, Rinehart, and Winston.

Kline, Elios J. (1933). Significant changes in the curve of elimination since 1900. Journal of Educational Research, 27, 608-616. 
Kumar, Vasant, \& Bergstrand, Joy. (1979). Follow-up of high school non-completers, 1967-1976. (ERIC Documnt Reproduction Service No. ED 222 60?

Langsdorf, Michael \& Gibboney, Richard A. (1977). The career intern program: Final report. Volume 1 (NIE Papers in Education and Work, \#). (ERIC Document Reproduction Service No. ED 142 795)

Layton, Warren K. (1953). Special services for the dropout and the potential dropout. NASSP Bulletin, 37, 193.

Lichter, Solomon 0., Rapien, Elsie B., Seibert, Frances M., \& Sklansky, Morris A. (1962). The Dropouts: A Treatment Study of Intellectually Capable Students who drop out of High School. Glencoe, IL: The Free Press.

Livingston, A. Hugh. (1958). High school graduates and dropouts; A new look at a persistant problem. The School Review, 56, 195-203.

Lloyd, Dee Norman. (1968). Antecedent relationships to high school dropout or graduation. Education, 89, 166-168.

Los Angeles Unified School District. (1974). Study of senior high school absentees and school leavers: An investigation of certain characteristics of absentees and school leavers in six senior high schools of Los Angeles Unified School District. Los Angeles, CA: Author. (ERIC Document Reproduction Service No. ED 102 476)

Los Angeles Unified School District. (1981). Graduation and attrition rates in Los Angeles City Senior High Schools Class of 1981 (Publication \#408). Los Angeles, CA: Los Angeles Unified School District, Research and Evaluation Branch.

Los Angeles Unified School District. (1982). Early School Leavers: High School Students who Left School Before Graduating, 1980-81 (Publication No. 406) Los Angeles, CA: Los Angeles Unified Schoo1 District, Research and Evaluation Branch.

Mahan, Guy \& Johnson, Charles. (1983). Portrait of a dropout: Dealing with academic, social and emotional problems. NAASP Bulletin, 67, 80-83.

Mann, David W. \& Gold, Martin. (1981). Alternative schools for disruptive secondary students: Testing a theory of school processes, students' responses, and outcome behaviors. (Report No. 6-0284). Washington, D.C.: National Institute of Education.

Maurer, Richard E. (1982). Dropout prevention: An intervention model for today's high schools. Phi Delta Kappan, March 1982, 470-471. 
McCauley, Brian \& Dormbusch, Sanford M. (1978). Students who choose alternative public high schools--their background, their education and their academic achievement: A comparison of matched samples. In Terrence E. Deal and Robert F. Nolan, (Eds.). Alternative schools: Ideologies, realities, guidelines. (221-229). Chicago, IL: Nelson Hall.

McClelland, David E. \& Alschuler, Alfred S. (1971). Achievement motivation development project: Final report. Cambridge, MA: Harvard University. (ERIC Document Reproduction Service No. ED 062 585)

McDill, Edward L., Meyers, Edmund D., \& Rigsby, Leo C. (1967). Institutional effects on the academic behavior of high school students. Sociology of Education, 40, 181-199.

McDonald, Everett A., Jr. (1953). Comments on how can a school increase its holding power of youth? NASSP Bulletin, 37 (194), 189-192.

McPartland, J. M. and Epstein, J. L. (1977). Open schools and achievement: Extended tests of a finding of no relationship. Sociology of Education, 42, 133-144.

Mertens, William J. (1971). Review and Assessment of ESEA Title VIII Bropout Prevention Projects for Fiscal Year 1971. (ERIC Document Reproduction Services No. ED 103 577)

Mertens, William J. (1972). Review of some Dropout Research and Literature. (ERIC Document Reproduction Services No. ED 116 103)

Miller, Robert A. (1981). The Federal Role in Education: New Directions for the Eighties. Washington, D.C.: The Institute for Educational Leadership.

Miller, S. M. (1967). Dropout; - A political problem. In Daniel Schreiber (Ed.), Profile of the school dropout (pp. 184-197). New York: Random House.

Minnesota State Department of Education. (1981). Secondary School Dropouts. St. Paul, MN: Author. (ERIC Document Reproduction Services No. ED 205 684)

National Advisory Council on Supplementary Centers and Services. (1975). Dropout Prevention: A Special Report.

National School Public Relations Association. (1972). Dropouts: Prevention and Rehabilitation. Washington, D. C.: Author. 
Neill, Shirley Boes, (Ed). (1979). Keeping students in school; Problems and solutions. (AASA Critical Issues Report). Sacramento, CA: Education News Service.

Nelsen, Ralph T. (1975). FOCUS: An alternative model that works. Phi Delta Kappan, 56, 631 .

Nirenberg, John. (1977). A comparison of the management systems of traditional and alternative public high schools. Educational Administration Quarterly, 13(1), 86-104.

Oregon Department of Education. (1980). Oregon Early School Leavers Study, 1980. Salem, OR: Author.

Ornstein, Allan C. \& Levine, Daniel U. (1981). Strategies for reforming metropolitan schools. Urban Education, 16(1), 93-107.

Ornstein, Allan C., Levine, Daniel U., \& Wilderson, Doxey A. (1975). Reforming metropolitan schools. Pacific Palisades, CA: Goodyear.

Patterson, Walter F. (1955). What are the causes of student dropouts and what should the school do about the present condition? NASSP Bulletin, 39(210), 85-88.

Portland Public Schools. (1980). Manual for developing a school-within-a-school alternative program. Portland, OR: Author (ERIC Document Reproduction Service No. ED 117 236)

Raywid, Mary Anne. (1981). The first decade of public school alternatives. Phi Delta Kappan, 62, 551-559.

Raywid, Mary Anne. (1983). The current Status of Schools of Choice in Public Secondary Education. Hempstead, N.Y.: Hofstra University Project on Alternatives in Education.

Raywid, Mary Anne. (1984). Synthesis of research on schools of choice. Educational Leadership, 41(7), 77-78.

Riordan, Robert C. (1972). Alternative Schools in Action. Bloomington, IN: Phi Delta Kappan Educational Foundation.

Ross, Victor J. (1983). Find potential dropouts early, then help them stay in school. The Executive Educator, 5 (6), 16-17.

Rumberger, Russell W. (1983). Dropping out of high school: The influence of race, sex, and family background. American Educational Research Journal, 20, 199-220.

Scales, Henry H. (1969). Another look at the dropout problem. Journal of Educational Research, 62, 339-343. 
Schaefer, Walter E. \& Olexa, Carol. (1971). Tracking and opportunity. Scranton, PA: Chandler.

Schreiber, Daniel, (Ed.) (1964). The School Dropout. Washington, D.C.: National Education Association.

Schreiber, Daniel, (Ed.) (1967). Profile of the School Dropout. New York: Random House.

Schrumpt, Fred \& Kurtz, Don. (1980). Developing alternative education options. NASSP Bulletin, 64, 39-48.

Sewell, T. S., Manni, J. L., \& Palmo, A. J. (1981). High School dropout: Psychological, academic, and vocational factors. Urban Education, 16 (2), 65-76.

Sexton, Porter. (1984). Trying to make it real cormpared to what? Implications of high school dropout statistics. Manuscript submitted for publication.

Sheridan School District \#2. (1972). Project outreach for optimum growth of alienated youth who reject school continuation application: Dropout prevention program, 1972-73. Englewood, C0: Author. (ERIC Document Reproduction Service No. ED 074 201)

Smith, Gerald R., Gregory, Thomas B., \& Pugh, Richard C. (1981). Meeting student needs: Evidence for the superiority of alternative schools. Phi Delta Kappan, 62, 561-564.

Smith, Vernon H. (1973). Options in public education: The quiet revolution. Phi Delta Kappan, 55, 434-437.

Smith, Vernon, Barr, Robert, \& Burke, Daniel. (1976). Alternatives in Education: Freedom to Choose. Bloomington, IA: Phi Delta Kappan.

Snepp, Danie1 W. (1953). Why they drop out: Eight clues to greater holding power. The Clearing House, 27, 492-494.

Stake, Robert E. (1976). Evaluating educational programnes. Paris, France: Organization for Economic Cooperation and Development, Centre for Educational Research and Innovation.

Stoughton, Charles R. \& Grady, Beverly R. (1978). How many students will drop out and why? The North Central Association Quarterly, 53, 312-315.

Stroup, Atlee L. \& Robins, Lee N. (1972). Elementary school predictors of high school dropout among black males. Sociology of Education, 45, $212-221$.

Tesseneer, R. A. \& Tesseneer, L. M. (1958). Review of the literature on school dropouts. NASSP Bulletin, $\underline{42}$ (238), 141-153. 
Thornburg, Hershel D. (1975). Attitudinal determinants of holding dropouts in school. Journal of Educational Research, 68 (5), 181-185.

Thorndike, Edward L. (1907). The elimination of pupils from school (U.S. Bureau of Education, Bulletin \#4). Washington, D.C.: U.S. Government Printing Office.

Tyack, David B. (1974). The one best system. Cambridge, MA: Harvard University Press.

Underwood, Rita E. (1980). Dropout turnaround through ESEA Title IV, Part C. Washington, D.C.: U. S. Department of Education (ERIC Document Reproduction Services No. ED 197 274)

United States Department of Labor. (1960). School and early employment experiences of youth: A report on seven communities 1952-57. (Bulletin \#127). Washington, D.C.: U. S. Government Printing Office.

United States Office of Education. (1973). Positive approaches to dropout prevention (DHEW OE Publication No. 73-12300). Washington, D.C.: U. S. Government Printing Office.

Urdal, Lloyd B. (1963). Dropouts: An Analysis of personal variables within the school situations. Olympia, WA: Office of the State Superintendent for Public Instruction.

Vincenzi, Harry \& Fishman, Roger J. (1978). Impact of alternative programs on an urban school district. Paper presented at the annual meeting of the American Educational Research Association, Toronto, Ontario. (ERIC Document Reproduction Service No. ED 152 938)

Voss, Harwin L., Eliiot, Delbert S., \& Wendiling, Aubrey. (1966). Journal of Educational Research, 50, (8), 363-367.

Wisconsin Vocational Studies Center. (1980). Study of programs for potential dropouts, phase I: Final Report. Madison, WI: Author.

Wolf, Robert L. \& Tymitz, Barbara. (1977). Toward more natural inquiry in education. CEDR Quarterly, 10, 7-9.

Wootten, Marian, Matthews, Tom, \& Fong, Susan. (1982). Case Studies of Selected Alternative Schools, (Volumes 82-10 A-F). Seattle, WA: Seattle Public Schools.

Yaffee, Elaine. (1982). More sacred than motherhood. Phi Delta Kappan, 63, 469-472.

Young, Vivienne \& Reich, Carol. (1974). Patterns of Dropout. (Report \#129). Toronto, Ontario: Board of Education Research Service. (ERIC Document Reproduction Service No. 106 720) 
APPENDIX A:

DESCRIPTION OF ALTERNATIVE PROGRAMS

SELECTED FOR THE STUDY

\section{EXISTING DISTRICT EDUCATION OPTION PROGRAMS}

\section{Introduction}

The school district provides students the opportunity to pursue their schooling in regular or non-traditional alternative programs. Alternative programs take the place of the regular program for those students who are generally unsuccessful in the regular school setting. The alternatives primarily serve a high school population, and, in a given school year, altogether they typically provide programs for 1,000 students.

Students Served by Internal Programs

Participation in the internal alternative programs is usually a consequence of the student's inability to succeed both academically and sccially in a regular school program. Services are designed to meet the needs of the student who is classified as a "potential dropout," or "early leaver." Alternative programs provide an equivalent educatonal program for these students who have a history of some kind of failure in the regular school.

Alternative school programs help their students confront the dissatisfaction, disaffection or failure they experience in the regular school prograns, help them renew their commitment to education in an alternative cnvironment and prepare them for graduation and responsibilities, work, and citizenship. 
Programs and Objectives

The chief goal of the alternatives is to provide varying kinds of positive and supportive environments for learning, so that potential dropouts will in fact be able to remain in an educational setting with a greater probability of success for high school graduation and preparation for acceptance of the responsibilities of adult life employment. Five programs provide instruction on a full-time basis.

Students in Alternative Programs $D$ and E participate full-time in "in-house" programs which operate on schedules concurrent with the regular school programs when students appear to have an improved chance for success. Each of these programs is sensitive to student ties to the larger school culture. Each attempts to reflect the positive aspects of formal schooling by providing potential dropouts a reasonable opportumity to succeed within the confines of their regular high schools.

Full-time comprehensive high school education in a separate physical setting, or a different time frame from the regular school, is provided at Programs A, B, and C; B and C also offer preparation programs for the Graduation Equivalency Program (GED).

Facilities and resources of the host high schools are generally available, and administrative and staff support for the internal alternatives is positive. Only Programs $B$ and $D$ provide for vocational or work experience. 


\section{Alternative Program A}

The basic skills delivery system for high school students is eclectic. Individually prescribed instruction has been implemented using a skill development sequence (based on task and factor analysis). To accomnodate this format, formal evaluation occurs bi-annually in addition to aistrict-wide competency tests. The reading programs are as varied (Psycholinguistics to VAKT) as are the teaching strategies (precision teaching to independent study or peer tutoring). Mathematics is also individualized and goal oriented. Specialized programs (i.e., ICSP) compliment teacher-made management systems in conjunction with a "hands-on" lab approach. High school students are required to participate in the Basic Skills Core until they have accumulated sufficient credit (towards graduation) and have achieved a minimum competency level on 8th grade. Target students are those children functioning significantly below grade level, yet do not qualify for Special Education. Target students receive additional instruction in the remedial lab. Emphasis is placed on test- taking and study skills.

\section{Alternative Program B}

Basic education skills, as well as vocational skills, are offered at Program B to students who have opted out of the conventional academic high schools and who would ordinarily not complete high school.

Individualized interdistiplinary instruction is given in mathematics, reading, and communication skills necessary so that students are prepared emotionally and academically for successful job 
entry. Basic skills teachers achieve these educational ends by a combination of job sheets with intensive personalized teaching.

\section{Alternative Program D}

Program D emphasizes basic skills instruction in the following ways: They test their students each fall and program students needing skill development into small group situations. They conduct a reading skill lab, a writing skills lab, and a mathematic skills lab. Students are required to take these courses until they show by tests that they no longer need them.

\section{Alternative Program E}

Program E is a school within a school to serve youth unable to cope with more conventional forms of instruction. Students receive individual and small group instruction based on varying abilities and attention spans. Although the Option meets the needs of both the capable and less capable students, instruction is directed toward all basic skills, particularly math, reading, composition, and basic social studies concepts based on individual need. 
APPENDIX B

Preliminary Exercise to Determine the Availability of a History of Educational Experiences from Data Base Systems and Cumulative Records

Carolyn Moilanen

November, 1983

The preliminary draft of my research proposal poses this question: What have been the educational experiences of students within a school system prior to their entry to alternative programs?

Much of the research on alternative student populations seeks to identify personal/social characteristics of this group, and most often such descriptors are drawn in terms of "deficit" characteristics whose treatment is typically outside the scope of a regular public school educational program. My purpose is to describe the educational experiences provided within the regular program.

Because of the development of compensatory and supportive educational programs within regular school offerings, it is reasonable to inquire whether an alternative population has been variously identified by early participation in such programs, or whether this group has indeed "fallen through the cracks" with its educational needs 
overlooked. If the educational histories of alternative students display participation in an array of supportive programs, this information may provide an insight to early identification of potential populations and may suggest treatment trends which support successful completion of high school.

Is a history of the educational experiences of alternative populations available? If available, how accessible and valid are its elements?

To answer these questions, it was first necessary to determine the nature, extent and accessibility of appropriate information. Two main sources were identified for initial consideration: 1) school district data base systems, and 2) cumulative record folders.

At present there are three data base systems useful to obtain historical information on students' educational experiences: 1) Student Master File, 2) Test Data Base, 3) Office of Management Information Services history tapes. Two supplementary resources available from Management Information Services are files containing Student Withdrawal Applications and Enrollment Reports for years 1972 through 1983 which chronicle school building code changes, school closures and in-building grade level organizational changes.

Student identification numbers entered into the Test Data Base produce district achievement scores for mathematics, reading and language usage. Achievement scores are obtained from district-wide administered tests given fall and spring of each year for grades 3-8. The mathematics and reading tests were first used in 1977, and language usage was first used in 1979. 
History tapes include information from the past three school years, 1980-1981, 1981-1982 and 1982-1983. A correlation of "averaged" attendance and grads point average as well as suspension data is included on the tapes.

The limitations of the Student Master File include the following:

1. Only one Entry/leave code per year is provided, and therefore the last entry made is that which appears on the file. If a student entered a school, withdrew and attended a private in-district school, withdrew and re-entered a public school--all within a single school year--only the final Entry code would appear on the file.

2. Special Education codes provide service information, but do not always include descriptor codes as to the exact nature of service.*

* Subsequent to this pilot study, location of Special Education files were located within the Department of Special Education. Information available therein effectively dispels this limitation.

3. Title I provides a code $Y$ to indicate "yes" for participation in Title I reading, math or language usage. An $\mathrm{N}$ indicates that a student did participate during a school year, but was then withdrawn from service. Individual schools enter $\mathrm{N}$ codes variously.*

4. While participation in Special Education requires an extensive and systematic preparation, participation in Title $I$ is either by low achievement score or teacher judgment. The Student Master File does not indicate which criteria was used for individual students.

Cumulative record folders present general personal and demographic information for students, names of schools attended and extensive elementary school year information on attendance, copies of report cards, information about specialized testing, placement and participation, achievement scores, behavioral records and occasional anecdotal teacher comments on achievement and/or behavior. There is less high school information. 
The limitations of the cumulative record folders include the following:

1. The information is not consistently or systematically entered from year to year. More striking differences are noted in entries from school to school.

2. Though the folders are generally divided into "Progress" and "Behavior" records, there are no apparent criteria which direct records into one category or the other, which results in un-systematic placement and/or correlation of materials.

3. Information is not always complete within a cumulative record folder. Fragmentary reports, faded copies of reports and information, or missing bits of information is common.

* Subsequent to this pilot study, more precise data has been located in the Evaluation Department's Title I files which more accurately record nature and length of participation in Title I programs.

When the two sources of information--Data Base systems and cumulative record folders--are accessed separately, a first impression is that the cumulative folders contain richer, but more sparse information about educational experiences. However, using the information from both sources to validate the other enables one to develop fuller descriptions of student school experiences, and often allows one to interpret seemingly "random" notations in the cumulative folders and entries on the data base.

The goal of this study was to access data base systems and cumulative record folders in order to trace the educational experiences of a sample of high school students within a district, prior to their entry to an alternative school program.

Sex

Date of Birth

Ethnic 
North

Northeast

Southeast

Southwest

Total \# Residence

Entry to PPS/Grade level, year

Number of schools attended in PPS

Special Education/Grade level

Title I/Grade level

Other Alternative Programs/Grade level

Mathematics Score/Pass, fail

Reading Score/Pass, fail

Language Usage Score/Pass, fail

Suspensions

Early leaving/dropout

Grade level and date

Entry Alternative 
Table A

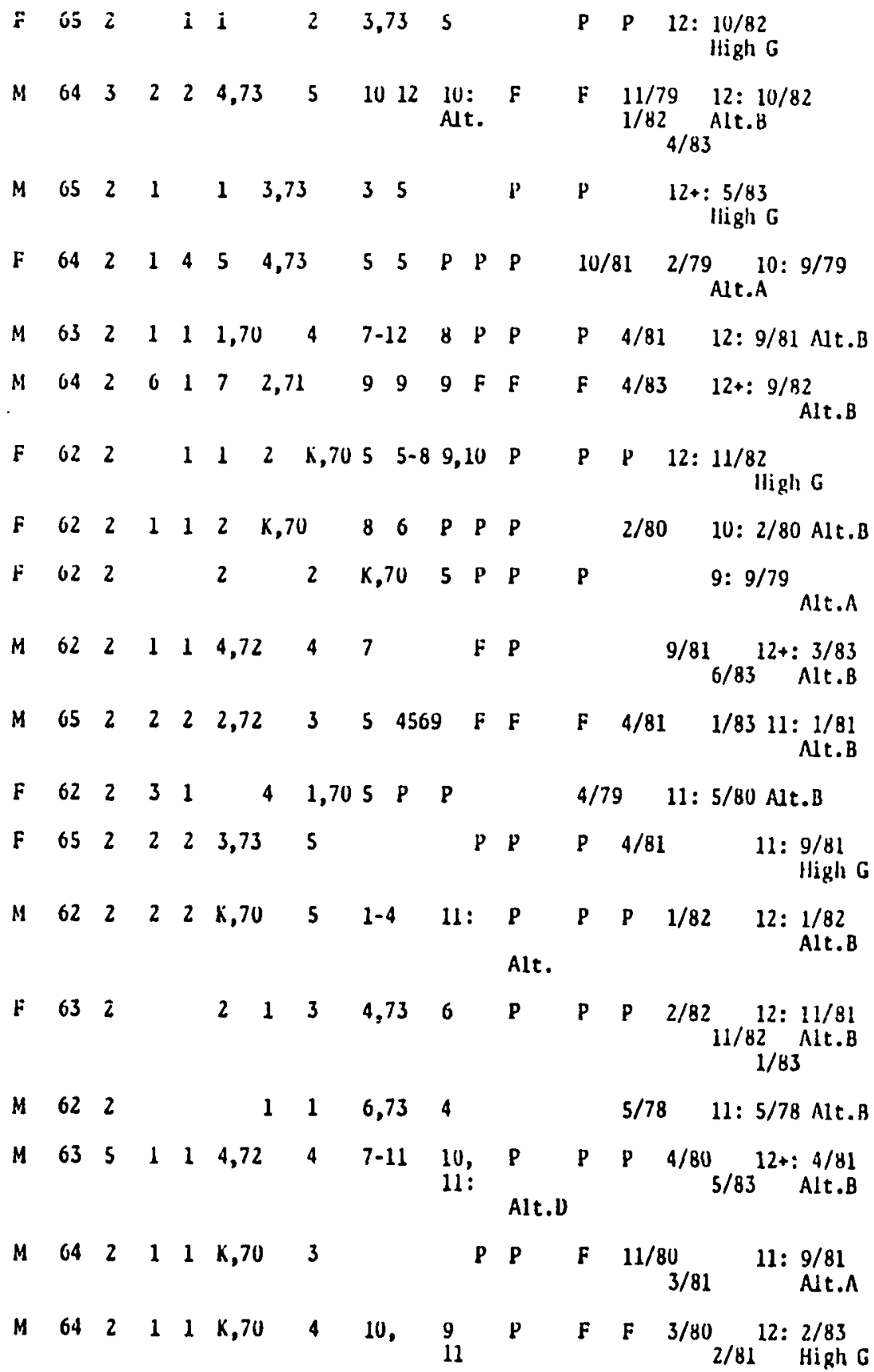


Over half of the student sample are males. One-third of the entire sample reached the age of 21 during the 1983 calendar year, which was the year of final graudation from high school for 13 students; six dropped out early in 1983. Only two students were not identified as white by ethnic code (2)--one student was Black (3) and one Spanish (5). Only one of the sample entered the district in grade six; all the others entered during the primary years, with the largest number remaining in the system since kindergarten. Table $B$ describes these sub-groups.

Table B

\begin{tabular}{|c|c|c|c|c|c|c|c|c|c|c|c|c|c|c|c|}
\hline Students & $\mathrm{N}$ & $\begin{array}{c}\text { Date } \\
62\end{array}$ & of & $\underset{64}{B i}$ & $\begin{array}{l}\text { rth } \\
65\end{array}$ & Ethnic & & & Gra & & vel & & & $4^{\text {to }}$ & $\begin{array}{l}\text { System } \\
5\end{array}$ \\
\hline $\begin{array}{l}\text { Male } \\
\text { Female }\end{array}$ & $\begin{array}{r}11 \\
8\end{array}$ & $\begin{array}{l}3 \\
4\end{array}$ & $\begin{array}{l}2 \\
1\end{array}$ & $\begin{array}{l}4 \\
1\end{array}$ & $\begin{array}{l}2 \\
2\end{array}$ & $\begin{array}{l}9 \\
8\end{array}$ & 1 & 1 & $\begin{array}{l}3 \\
3\end{array}$ & $\begin{array}{l}1 \\
1\end{array}$ & 2 & $\begin{array}{l}1 \\
2\end{array}$ & & $\begin{array}{l}3 \\
2\end{array}$ & 1 \\
\hline Tọtals & 19 & 7 & 3 & 5 & 4 & 17 & 1 & 1 & 6 & 2 & 2 & 3 & 3 & 5 & 1 \\
\hline
\end{tabular}

Table C presents the total number of schools attended by the same population. A reference to the Enrollment Reports determined that for four students in the sample, a school closure or grade level organizational change required that they change schools: 1) two sixth graders had to move to a new middle school when home $\mathrm{K}-\mathrm{-8}^{\prime} \mathrm{S}$ were reorganized as $\mathrm{K}-5 ; 2$ ) one ninth grader had to change high schools when hers closed; 3) one tenth grader had to change high schools when her school of attendance closed. 
Table C

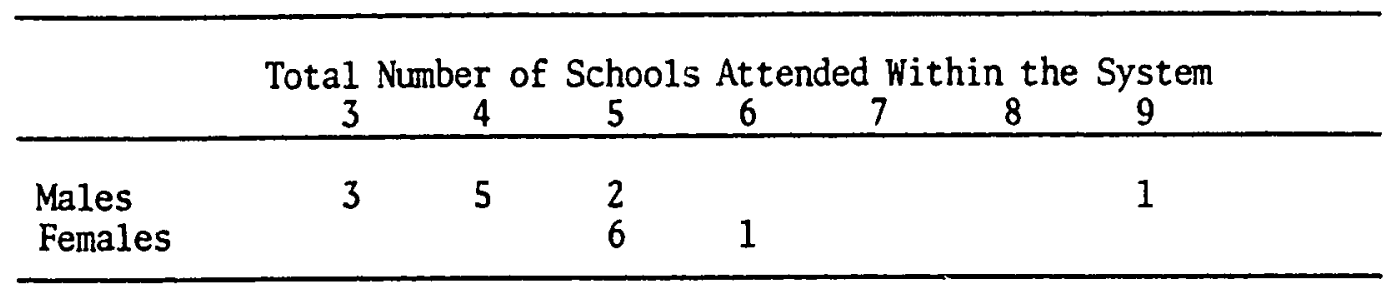

If a student were in the system since elementary school, it is likely that he would attend at least three schools during his year in the system--an elementary school, a middle school and a high school. When one alternative is added, the reasonable average would be four schools attended. This implies that the student did not move during his years within a school district. Some students may have had the experience of attending K-8 elementary schools, a high school and an alternative for a total of three schools.

A clear majority of the sample students attended five or fewer schools; when one considers that four students had to change schools due to closures and organizational changes and discounts for those four changes, the majority of students attended four or fewer schools which does not indicate the high rate of transfer frequently associated with the high risk alternative population.

Table D presents one other variable regarding school attendance: the grade level at entry to alternatives.

Table D

\begin{tabular}{lllll}
\hline Grade Level at Entry to Alternative & 9 & 10 & 11 & 12 \\
\hline Males & 0 & 0 & 3 & 8 \\
Females & 1 & 2 & 2 & 3 \\
\hline
\end{tabular}


While much of the alternative research indicates that students seek alternative situations earlier on in their high school careers, this particular sample is composed largely of students who entered during their final years of high school, relatively near to high school graduation. Only one student chose alternative placement for her entire high school career.

Table E

\begin{tabular}{lccc}
\hline & $\begin{array}{c}\text { Entry Near } \\
\text { Suspension }\end{array}$ & $\begin{array}{c}\text { Entry Related } \\
\text { to Dropout }\end{array}$ & $\begin{array}{c}\text { Unidentified } \\
\text { Reason }\end{array}$ \\
\hline Males & 2 & 4 & 3 \\
Females & 1 & 3 & 3 \\
\hline
\end{tabular}

Six of the sample students dropped out of their final alternative placement after entry. Four of them had dropped out at least once earlier.

In terms of supplementary services provided this group before their entry to alternatives, Table F displays absence of services, Special Education and Title I services.

Table F

\begin{tabular}{lccccc}
\hline & $\begin{array}{c}\text { No Earlier } \\
\text { Services }\end{array}$ & $\begin{array}{c}\text { Special } \\
\text { Education }\end{array}$ & $\begin{array}{c}\text { Title } \\
\text { I }\end{array}$ & $\begin{array}{c}\text { Other } \\
\text { Alternatives }\end{array}$ & $\begin{array}{c}\text { Sp. Ed. + } \\
\text { Title I }\end{array}$ \\
\hline Males & 2 & 9 & 5 & 3 & 5 \\
Females & 5 & 2 & 2 & 0 & 1 \\
\hline Totals & 7 & 11 & 7 & 3 & 6 \\
\hline
\end{tabular}


A clear majority of the group had supplementary services for one or more years during their regular schooling experience, which may be a reasonable indicator of their need for alternative programing for a more extended period. of the three male students who participated in other alternatives prior to their final high school placement, one received Special Education, Title I services and participated in an in-school alternative program. The other two students who participated in different alternative schools-within- schools also received Special Education services.

Achievement is presented in Table $G$, which identifies numbers of students passing or failing the district-wide basic skills tests in mathematics, reading and language usage.

Table G

\begin{tabular}{|c|c|c|c|c|c|c|c|}
\hline & \multicolumn{2}{|c|}{ Mathematics } & \multicolumn{2}{|c|}{ Reading } & \multicolumn{2}{|c|}{ Language Usage } & \multirow[b]{2}{*}{ No Score } \\
\hline & Pass & Fail & Pass & Fail & Pass & Fail & \\
\hline $\begin{array}{l}\text { Males } \\
\text { Females }\end{array}$ & $\begin{array}{l}6 \\
8\end{array}$ & $\begin{array}{l}2 \\
0\end{array}$ & $\begin{array}{l}5 \\
8\end{array}$ & $\begin{array}{l}2 \\
0\end{array}$ & $\begin{array}{l}2 \\
6\end{array}$ & $\begin{array}{l}3 \\
0\end{array}$ & $\begin{array}{l}1 \\
0\end{array}$ \\
\hline Totals & 14 & 2 & 13 & 2 & 8 & 3 & 1 \\
\hline
\end{tabular}

Regarding suspension, expulsion and dropout, of the 19 students in the sample, four males and two females were suspended from school at least once; two of the males were suspended more than one time. Eleven students withdrew at least once during their high school years. Five left during their regular school experience and returned to complete high school in alternatives. The remaining six dropped out both before and after entering the alternative high school programs. 
Cumulative Records. Cumulative record folders present general personal and demographic information for students; names of schools attended; extensive elementary school year information on attendance, copies of report cards, information about specialized testing, placement and participation, achievement scores, behavioral records, and occasional anecdotal teacher comments on achievement and/or behavior. There is less high school information.

The limitations of the cumulative record folders include the following:

1. The information is not consistently or systematically entered from year to year. More striking differences are noted in entries from school to school.

2. Though the folders are generally divided into "Progress" and "Behavior" records, there are no apparent criteria which direct records into one category or the other, which results in un-systematic placement and/or correlation of materials.

3. Information is not always complete within a cumulative record folder. Fragmentary reports, faded copies of reports and information, or missing information are cormon.

When the two sources of information--Data Base systems and cumulative record folders--are accessed separately, a first impression is that the cumulative folders contain richer, but more sparse information about educational experiences. However, using the information from both sources to validate the other enables one to develop fuller descriptions of student school experiences, and often allows one to interpret seemingly "random" notations in the cumulative folders and entries on the data base. 
APPENDIX C:

STUDENT INTERVIEW SCHEDULE

LETTERS TO INTERVIEW SUB-SAMPLE

CONSENT FORMS

MTERVIEW STIEDURE

I an interested in knowing about your educational experiences in the schools before you entered ___ Since you have been in both a regular and an alternative school progiam, I'd like you to help me learn about the similaricies and differences between the two. I an going to ask you some questions, and I will be taking notes as you respond.

Before we begin, let ine remind you of the informed consent agreement.

Date: __ Time: __ Interview No.

ID\# / Nane / Grade / D.O.B. / Entry / Alt

1. What grade are you in?

$9 \quad 10 \quad 11 \quad 12$

2. Who do you live with? both parents one parent alone other

3. How many brothers and sisters do you have? brothers ages sisters ages

4. Did you ever repeat a grade? No Yes 123456789101112

5. Did you ever skip a grade? No Yes

6. Have you ever dropped out? No Yes 123456789101112 Grade Level / Durarion 
7. How long have you been at ? (Entered about Where did you go to high school before? Middle school? Grade school?)

Now I'd like to ask you some questions about school here.

8. Whit are the attendance requirements here? What are the school rules rezarding attendance? Length of courses? Credit/atiendance?

9. What are the coursework requirenents? How much work is required? How do you eam credit? Do you receive grajes? What is quality of work -difficuli/easy?

10. What classes are you taking this term?

11. Are these the same kinds of courses that you would be taking in the regular high school projram? Are the course requirenents the sane? Is the work similar, more difficult, or casies? 
12. Besides your classes, what school activities do you participate in here?

1j. In your opinion, what are the main differences between regular school and the alternative program here at ?

14. Tell me about your relationship with the tearhars here.

15. I'd like you to describe yourself as a leamer and tell me what kind of studeni you are.

16. How do you feel about school in general?

17. Before you came to how were you doing in school? What were the attendance requirements! The course requirements? 
18. Here is a list of conmon problems students have in school. (Give copy to interviewee). I'm going to read through the list with you. TIease tel1 me if you have ever had any of these problems.

a. Atzendance (missing too many days

No Yes to earn credit or to keep up with my work)

b. Problems with friends, people my own age (Did you always have Eriends in school?

No Yes Elementary, middle, high?)

c. Problems with teachers

No Yes

d. Problems with administrators

No Yes

e. Suspended/expelled

No Yes

f. Stresstul school atmosphere

No Yes

g. Too many students at my school (too crowded)

No Yes

h. I didn't fit in

No Yes

i. Fear for my safety at school

No Yes

j. Couldn't get classes I wanted

No Yes

k. Couldn't get enough help from teachers

No Yes

1. Bored, not interested in classhork

No Yes

m. Lack of credics (too far behind

No Yes to casch up)

n. Poor grades, failing

No Yes

o. Other:

ivo Yes 
19. When you were in grade school and middle school, how did your icarhers help you most?

20. How did your high sehool teachers help you?

21. In the regular program, did you ever go to special classes, or get special help from a teacher?

22. In the regular progran, did you ever receive special help from a tutor, or an aide?

25. Did you ever participate in any of these prograns?

\begin{tabular}{ll}
\hline & Yes \\
\hline & Yes \\
Yes \\
Special Education & Yes \\
Talented and Gifted (TAG) & Yes \\
Title I or Chapter I & Yes \\
& Yes \\
& Yes
\end{tabular}

24. Did you ever feel successful in the regular school program? (How did you know when you were suecessful in the regular school progian?) 
25. What kinds of school activities did you participate in when you were attending the regular school prograu? (a. Did you try to get out of participating in school activities? b. Ibw sucesssful were you? c. Did you try to get other activities going instead? e. How successful were you?)

a.

b.

c.

d.

26. Why did you leave your regular high school?

27. How did you decide to come to ? (How did you find out about ? Who nelped you io enroll here? Did you know of other alcernarive prograns? Did you enroll anywinere else? Did ycu have to wait before entry?

28. What did you hope to gain by enrolling here at ?

29. Do you feel that you are successful here at you kJow when you're suczessiul at ? (How do

30. How long do you plan to siay at Euture education plans or goals? , and wilas are your 
31. If you weren't enrolled here at the , where would you

32. iere is a list of alternative schools in any of them?

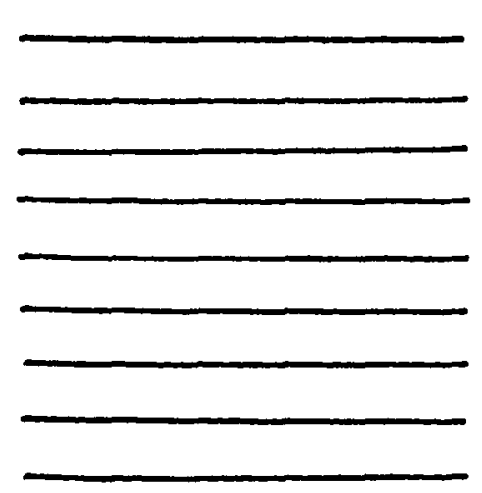

- Did you ever ditend

Date/Duration/Deserincion

Yes

Yes

Yes

Yes

Yes

Yes

Yes

Yes

Yes 
April 30, 1984

Dear Parents and Guardians,

Ms. Carolyn Moilanen of the School District is currentiy studying the educational histories of students in the district's alternative programs. As part of her study, she would lit:e to interview high school students in , to ask then about their educational exoeriences in both the regular and alternative programs.

Your student has been randomly selected to participate in a 30 minute interview which will take place during regular school hours. All responses will be confidential and used for research purposes only. Ho individual student names will appear in any reported information.

This project has the approval of the district Departnient of Research and Evaluation. If you agree that your student may participate, please read and sign the enclosed consent form and return it to

Thank you for your cooperation.

$$
\begin{aligned}
& \text { Sincerely, } \\
& \text { Carolyn Moilanen } \\
& \text { Evaluation Assistant } \\
& \text { Aiternative Prograin } \\
& \hline
\end{aligned}
$$




\section{INFORMED CONSENT FORM}

I agree that the student named below may be interviewed as a participant in the research study of Students in Alternative Public High Schools: Educational Histories Prior to Alternative School Entry.

I understand that anything said will be used for research purposes only, and that participants will be identified only by a code number and not by name.

I understand that participants are free to break off the interview at any time.

I have read and understand this agreement.

Signature of Parent or Guardian

Signature of Student

Date 
APPENDIX D:

DESCRIPTION OF INTERVIEN SUB-SAMPLE

Table $\mathrm{H}$ presents the interview sub-sample according to sex, grade level, and alternative program affiliation.

Table H

Interview Sub-Sample

\begin{tabular}{|c|c|c|c|c|c|c|}
\hline \multirow{2}{*}{\multicolumn{2}{|c|}{$\begin{array}{l}\text { Alternative } \\
\text { Program }\end{array}$}} & \multicolumn{4}{|c|}{ Grade Levels } & \multirow{3}{*}{$\begin{array}{c}\text { Total } \\
10 \\
14 \\
24\end{array}$} \\
\hline & & 9 & 10 & 11 & $\overline{12}$ & \\
\hline$A$ & $\begin{array}{l}\text { Male } \\
\text { Female } \\
\text { Total }\end{array}$ & $\begin{array}{l}3 \\
1 \\
4\end{array}$ & $\begin{array}{l}2 \\
3 \\
5\end{array}$ & $\begin{array}{r}3 \\
9 \\
12\end{array}$ & $\begin{array}{l}2 \\
1 \\
3\end{array}$ & \\
\hline B & $\begin{array}{l}\text { Male } \\
\text { Female } \\
\text { Total }\end{array}$ & $\begin{array}{r}1 \\
-- \\
1\end{array}$ & $\begin{array}{l}1 \\
3 \\
4\end{array}$ & $\begin{array}{r}7 \\
5 \\
12\end{array}$ & $\begin{array}{l}4 \\
3 \\
7\end{array}$ & $\begin{array}{l}13 \\
11 \\
24\end{array}$ \\
\hline$C$ & $\begin{array}{l}\text { Male } \\
\text { Female } \\
\text { Total }\end{array}$ & $\begin{array}{l}-- \\
11 \\
--\end{array}$ & $\begin{array}{l}2 \\
1 \\
3\end{array}$ & $\begin{array}{l}1 \\
2 \\
3\end{array}$ & $\begin{array}{l}1 \\
2 \\
3\end{array}$ & $\begin{array}{l}4 \\
5 \\
9\end{array}$ \\
\hline D & $\begin{array}{l}\text { Male } \\
\text { Female } \\
\text { Total }\end{array}$ & $\begin{array}{l}3 \\
2 \\
5\end{array}$ & $\begin{array}{l}3 \\
1 \\
4\end{array}$ & $\begin{array}{l}1 \\
2 \\
3\end{array}$ & $\begin{array}{l}2 \\
2 \\
4\end{array}$ & $\begin{array}{r}9 \\
7 \\
16\end{array}$ \\
\hline $\mathrm{E}$ & $\begin{array}{l}\text { Male } \\
\text { Female } \\
\text { Total }\end{array}$ & $\begin{array}{r}2 \\
--\end{array}$ & $\begin{array}{l}1 \\
4 \\
5\end{array}$ & $\begin{array}{l}-- \\
-- \\
--\end{array}$ & $\begin{array}{r}-- \\
1 \\
1\end{array}$ & $\begin{array}{l}3 \\
5 \\
8\end{array}$ \\
\hline \multicolumn{2}{|c|}{ Total } & $\begin{array}{c}12 \\
(15 \%)\end{array}$ & $\begin{array}{c}21 \\
(26 \%)\end{array}$ & $\begin{array}{c}30 \\
(37 \%)\end{array}$ & $\begin{array}{c}18 \\
(22 \%)\end{array}$ & $\begin{array}{c}81 \\
(100 \%)\end{array}$ \\
\hline
\end{tabular}




\section{Personal/Social Characteristics}

Twelve of the students interviewed were in grade nine; 21 were tenth graders; 30 were in grade 11 ; and 18 were in grade 12 . Twenty-one students had been enrolled at the alternative less than a year; 32 students had been enrolled from one to two years; 26 had been enrolled between two and three years; two students had been at the alternative program for four high school years.

Thirty-four interviewees (42q) lived with both parents; 27 (33\%) lived with their mothers; 11 (14q) lived with guardian(s) other than their parents; nine (11\%) lived with one natural parent and a step-parent. Seventy students (86\%) lived with one or both parents and 11 (14\%) resided with non-family members.

Ethnicity. Sixty-nine percent of the interview sub-sample were White, $5 \%$ were Hispanic, $4 \%$ were Native American, $4 \%$ were Black and $2 \%$ were Oriental.

Socio-Economic Status. Twenty-eight percent of the students interviewed were identified for low socio-economic status based on participation in the Free/Reduced lunch program.

Mobility. In terms of continuous district enrollment, 14\% (11 students) were not continuously enrolled. Six students were out of the district for one year, four students were out two years and one student was out three years. In terms of alternative program enrollment, $26 \%$ had been enrolled less than a year, $40 \%$ had been enrolled one to two years, $32 \%$ two to three years and 28 had been in the alternative program longer than three years. 
Twenty-six of the students interviewed (32\%) had dropped out of school prior to alternative entry for periods ranging from one month to two years during their middle or high school years. Twenty-four students remained out of school for less than a semester; two students reported that they remained out longer than a year. It is worthwhile to note that withdrawal form a regular high school is a requisite for enrollment in Alternative B; 14 of the 26 students who had remained out of school were enrolled in that program. Table I presents grade level(s) at which dropout occurred for 26 sub-sample interviewees.

Table I

Grade Level of School Dropout by Alternative Program

\begin{tabular}{cccccccc}
\hline $\begin{array}{c}\text { Alternative } \\
\text { Program }\end{array}$ & \multicolumn{7}{c}{ Grade Level } \\
\cline { 2 - 8 } & 7 & 8 & 9 & 10 & 11 & 12 & Total \\
\hline A & 1 & -- & 6 & 2 & -- & -- & 9 \\
B & -- & 1 & 4 & 3 & 5 & 1 & 14 \\
C & -- & -- & -- & -- & -- & -- & -- \\
D & -- & -- & -- & -- & 1 & -- & 1 \\
E & -- & -- & -- & 1 & -- & -- & 1 \\
\hline Total & 1 & 1 & 10 & 6 & 6 & 1 & 25 \\
\hline
\end{tabular}

Twenty-three students (30\%) of the interview sub-sample (14 females and 9 males) had withdrawn from school during their high school years and prior to entering the alternative programs. Nineteen of these students had dropped out during high school; 16 during grades nine and 
ten and seven during grades eleven and twelve. Duration of dropout ranged from one to three months to a full school year. Ten students returned to school in less than a month. Six students were out from one to three months and seven were out from four to six months. Only one student remained out for the entire school year.

Fourteen of these students returned directly to alternative programs and ten re-entered the regular high school system, and later transferred to an alternative setting. Of these 24 students, only two withdrew after they entered the alteinative; one after remaining just one quarter and the others after remaining sligtly longer than a semester.

School-Related Characteristics

Retention in Grade. Ten of the students in the interview sub-sample had been retained in the school district; three during primary (K-2), six during their intermediate elementary years (3-5) and one student at middle school.

Dasic Skills Achievement. Seventy-seven percent of the interviewees had passed the school district reading test, $16 \%$ did not pass, and scores were missing for six students. Sixty-seven percent of the students interviewed had passed the math test, $28 \%$ had not, and scores were missing for three students. Eighty percent had passed the language test, $10 \%$ had not, and scores were missing for eight students.

Suspension. Thirty-three percent of the interview sample had been suspended at least once during district enrollment. Seven students 
from Program A, nine from $B$, two from $C$, and nine from $D$ had a record of suspension. None of the interviewees from Program E had suspension records.

Supplementary Program Participation. Table $J$ describes the interview sub-sample's participation in supplementary programs/ experiences.

Table J

Participation in Supplementary Educational Experiences

\begin{tabular}{lccccccc}
\hline & Chap. I & $\begin{array}{c}\text { Special } \\
\text { Ed. }\end{array}$ & $\begin{array}{c}\text { Vocational } \\
\text { Supplements }\end{array}$ & $\begin{array}{c}\text { Other } \\
\text { Alt's. }\end{array}$ & $\begin{array}{c}\text { Talented } \\
\text { \& Gifted }\end{array}$ & $\begin{array}{c}\text { Teacher } \\
\text { Aide }\end{array}$ & None \\
\hline N & 21 & 11 & 6 & 18 & 10 & 1 & 48 \\
\hline
\end{tabular}

